André Affonso Mariscal

\title{
EXCLUSÃO NA REPRESENTAÇÃO DA PERSONAGEM HENRY JUNIOR EM HAM ON RYE, DE CHARLES BUKOWSKI
}




\section{EXCLUSÃO NA REPRESENTAÇÃO DA PERSONAGEM HENRY JUNIOR EM HAM ON RYE DE CHARLES BUKOWSKI}

Dissertação apresentada ao Programa de Pós-Graduação em Literatura da Universidade de Brasília, requisito parcial à obtenção do título de Mestre em Literatura.

Área de concentração: Literatura e Práticas Sociais

Linha de pesquisa: Representação na literatura contemporânea Orientador: Cláudio Roberto Vieira Braga

Brasília

UNB

Janeiro/2017 


\section{AGRADECIMENTOS}

Dedico este trabalho a Charles, o primeiro e talvez o único a me ensinar o valor do amor próprio.

Agradeço ao professor Cláudio Braga pelo esforço, paciência e ajuda.

E um agradecimento especial à existência de Bruno Roberti, Daniel Beim, Fernando Kiss, Ivan Pavlovsky e Natália Duda, de quem consegui fé naturalmente incondicional. 


\section{RESUMO}

Esta dissertação identifica e analisa conflitos sociais, psicológicos e culturais entre o indivíduo e a coletividade humana, representados respectivamente, por Henry Junior, personagem principal de Ham on Rye (1982), de Charles Bukowski e a sociedade estadunidense. Investiga-se como os ambientes hostis presentes no romance geram traumas que resultam em um conturbado desenvolvimento do sujeito. Henry Junior, um imigrante alemão vivendo nos Estados Unidos da América (EUA) no período entre guerras do século XX (1919-1939), tem a personalidade constituída com base em dois confrontos centrais: com o mundo exterior, representado pela nação, colegas de escola e pela família; e com o 'interior', feito das sequelas de embates constantes, que ocasionam a repulsa da personagem por si mesma. Empregando teorias sociológicas de mobilidade para abordar o 'exterior' e psicanalíticas para o 'interior', este estudo busca responder como tais confrontos geram a personalidade fragmentada do protagonista, que apesar de prejudicial, fazem com que a personagem adquira consciência de seu papel no mundo e questione como a sociedade estadunidense se articula coletivamente. A descoberta da leitura e do fazer literário, fundamentais na formação de Henry Junior, são também averiguadas. Por meio de uma abordagem político-dialética, examina-se como se dá o entrelaçamento de questões pessoais do protagonista de Ham on Rye com questões históricas, de classe e de formação de grupos, possibilitando-nos maior entendimento sobre o contexto histórico-social estadunidense no entre guerras e sobre como os indivíduos dos EUA respondem a demandas da coletividade em tal período.

Palavras-chave: Charles Bukowski; literatura estadunidense; displaçamento; indivíduo; coletividade. 


\begin{abstract}
This dissertation identifies and analyses social, psychological and cultural conflicts between the individual and the human collectivity, depicted respectively, by Henry Junior, the main character of Charles Bukowski's novel Ham on Rye (1982) and the American society. It is investigated how the hostile environments within the narrative produce traumas which result in a troubled development of the subject. Henry Junior, a German immigrant living in the United States of America (USA) during the inter-war period of the last century (19191939), has his personality constituted on the basis of two main confrontations: with the external world, represented by nation, class mates and his family; and with the 'internal', resulted from the constant clashes, leading to the protagonist's repulsion for himself. Utilizing sociological theories about mobility to approach the 'external' and psychoanalytical for the 'internal', this study attempts to answer how the aforementioned confrontations generate a character with a fragmented personality, which though initially harmful, make Henry Junior aware of his role in the world, impelling him to question how the American society articulates itself as a whole. The discovery of reading and writing, both fundamental in Henry Junior's formation, are also discussed. Through a political-dialectic approach, it is ascertained how the interweaving between Ham on Rye's protagonist's personal issues and questions of history, class and group formation happens, giving us the opportunity to understand better the America socio-historical context during the inter-war period and how the Americans respond to collective demands at such time.
\end{abstract}

Key words: Bukowski; American literature; displacement; individual; collectivity. 


\section{SUMÁRIO}

1. INTRODUÇÃO

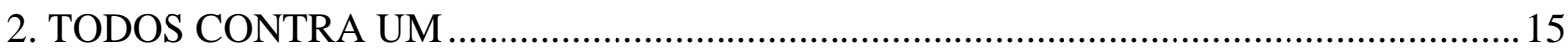

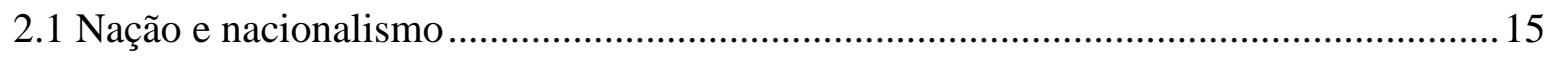

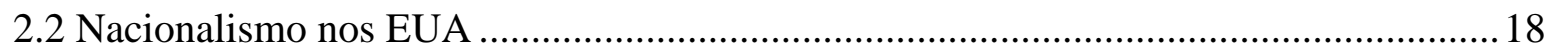

2.3 Making America, a cultura nacional em construção nos EUA ..................................... 19

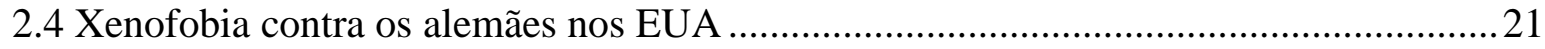

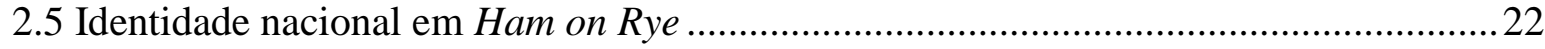

2.6 Esportes como símbolos na construção do nacionalismo estadunidense .......................29

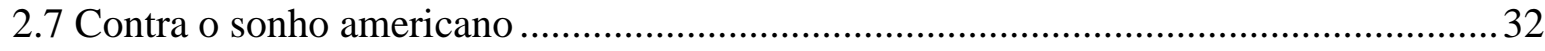

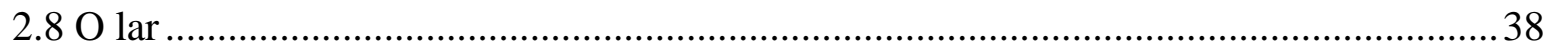

2.9 Identidade diaspórica e mobilidade como elementos do displaçamento social em Ham

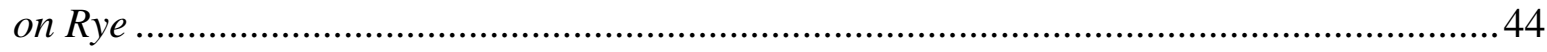

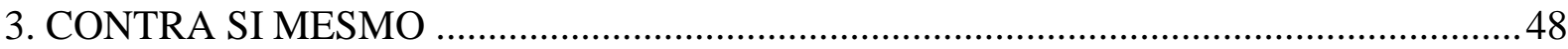

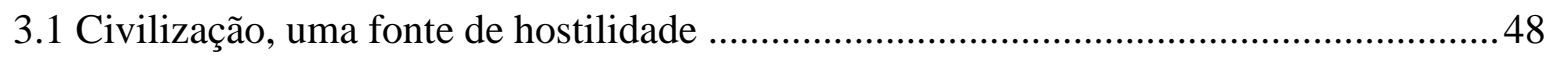

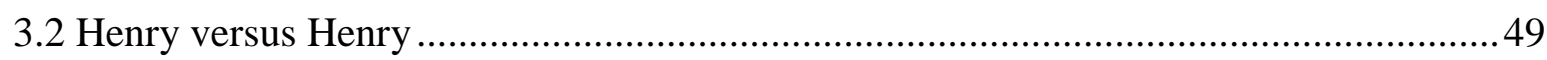

$3.3 \mathrm{O}$ inconsciente coletivo e os arquétipos de Jung em Ham on Rye ...............................52

3.4 Arquétipos e o processo de individuação de Henry Junior ..........................................53

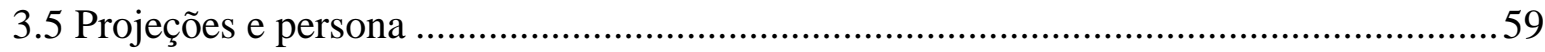

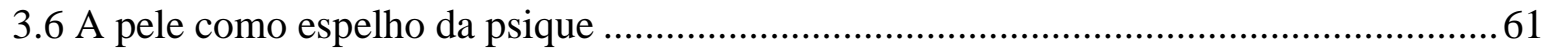

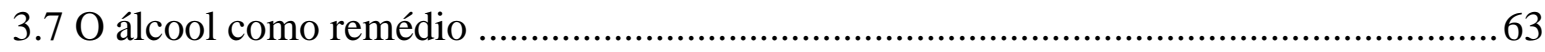

$3.8 \mathrm{O}$ desenvolvimento da personalidade de Henry Junior .............................................. 64

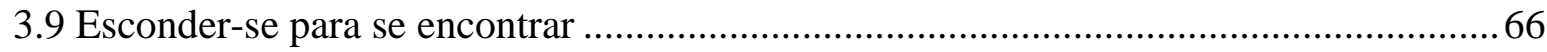

3.10 A arte como sublimação contra o displaçamento ...................................................... 69

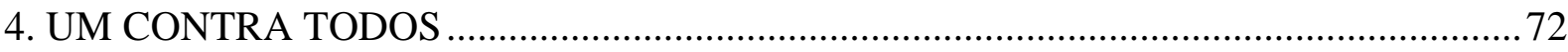

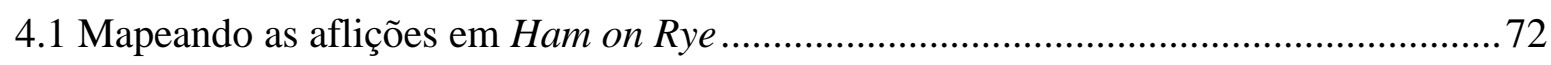


4.2 Conflito de classes em Ham on Rye

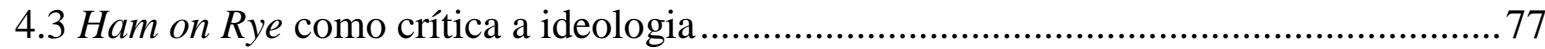

$4.4 \mathrm{O}$ realismo de Lukács e a figuração do displaçamento ................................................. 83

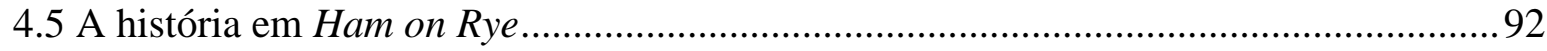

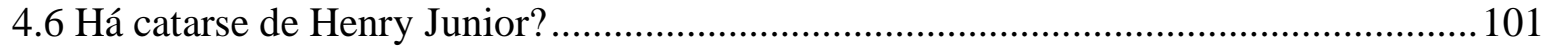

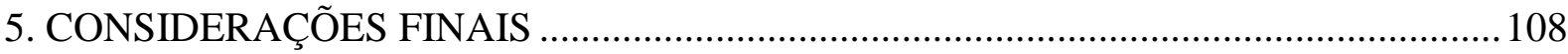

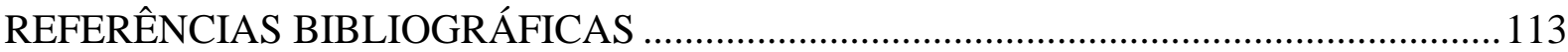




\section{DISPLACED}

\section{burning in hell}

this piece of me fits in nowhere as other people find things

to do

with their time

places to go

with one another

things to say to each other.

I am

burning in hell

some place north of Mexico.

flowers don't grow here.

I am not like

other people

other people are like

other people.

they are all alike:

joining

grouping

huddling

they are both

gleeful and content

and I am

burning in hell.

my heart is a thousand years old.

I am not like

other people.

I'd die on their picnic grounds smothered by their flags

slugged by their songs

unloved by their soldiers

gored by their humor

murdered by their concern.

I am not like

other people.

I am

burning in hell.

the hell of

myself.

(Charles Bukowski) 


\section{INTRODUÇÃO}

Neste estudo sobre o romance Ham on Rye (1982) de Charles Bukowski, há a presença de abordagens distintas, desde o uso de crítica literária per se até filosofia e psicanálise ${ }^{1}$. Essa mescla de disciplinas não é em vão e pode ser equiparada à visão que Jared Diamond (1997) tem sobre a história humana em camadas, como uma cebola. Nesta dissertação, Ham on Rye é visto da mesma maneira, e um tratamento exclusivamente histórico, ou sociológico ou então puramente psicanalítico faria com que somente uma camada superficial fosse investigada. Ao 'descascar' Ham on Rye, penetro em camadas mais profundas da narrativa, requerendo-me diferentes disciplinas para conseguir interpelar as conexões entre tais camadas. E como afirma o crítico literário Terry Eagleton ([1983] 1996), não há crítica literária pura, as artes estão entrelaçadas com história, política e sociedade.

Charles Bukowski (1920-1994), escritor longe de ser considerado unanimidade pela crítica literária e pelo público, ganhador do prêmio Outsider of the Year (CHERKOVSKI, 1991), possui um estilo único, que gera uma poesia contemporânea sem sentimentalismos e uma prosa crua. Por adotar temas desagradáveis e ser praticante do anticlímax, ele por vezes pode ser classificado como niilista. Por outro lado, sua ficção realista é repleta de um humor irônico e jocoso, e também é reconhecidamente enxertada com elementos autobiográficos. Nascido na Alemanha, Bukowski foi ainda criança para os Estados Unidos da América (EUA) com os pais. Sua história é marcada pelo desajuste social: teve problemas desde cedo com o pai, que o agredia, sofreu rejeição na escola, tornou-se alcoólatra e nunca se firmou em empregos. A paixão pela literatura e a consequente carreira de escritor parecem surgir como escapes em meio a tantas adversidades. Prolífico, Bukowski escreveu inúmeros poemas, crônicas, contos e seis romances, dentre estes, Ham on Rye (1982), que discuto e analiso nesta dissertação.

Escrito em primeira pessoa, Ham on Rye é um romance que dá voz ao protagonista Henry Chinaski Junior, um jovem alemão cuja família imigra para os EUA quando ele ainda é uma criança. Em capítulos sucintos e períodos curtos, o narrador descreve suas dificuldades em se relacionar com praticamente todas as pessoas e instituições desde muito cedo. O pai o

\footnotetext{
${ }^{1}$ Apesar de alguns termos e estudos relacionados às artes serem da psicologia, os principais autores utilizados nesta dissertação, Sigmund Freud, C. G. Jung e Jacques Lacan, possuem formação em medicina psiquiátrica e podem ser chamados de psicanalistas. Contudo, C. G. Jung é comumente chamado de pai da psicologia analítica e não convém chamá-lo de psicanalista. De qualquer forma, para fins didáticos e para o interesse desta dissertação, adotarei o termo psicanálise em detrimento do termo psicologia.
} 
espanca e o proíbe de brincar, especialmente de praticar esportes. Concomitantemente, em toda a vida escolar, Henry Junior se vê como um outsider, ora por sua aparência e atitude, ora por sua condição social e origem, gerando e complementando uma série de experiências de hostilidade e exclusão.

A fim de entender como a articulação da hostilidade da coletividade versus indivíduo se dá, recorro no primeiro capítulo desta dissertação a tópicos ricos à sociologia e à história, tais como: nação, guerra e cultura, os quais, paralela, dialética e consequentemente, também são de valia para os estudos literários em geral. A fim de analisar representações da sociedade e do indivíduo em Ham on Rye, cabem as perguntas: por que, quando e como tais disciplinas se comunicam entre si e qual o fruto de tais interações?

Um dos pilares culturais da humanidade, que funciona como liga entre os temas acima e a ser analisado nesta dissertação, é a linguagem. A habilidade de se comunicar e transmitir informações para futuras gerações nos faz uma espécie única e poderosa no planeta. Sistemas sanitários, pontes, computadores, automóveis e inúmeros outros exemplos de 'maravilhas' humanas com as quais interagimos e das quais dependemos, direta ou indiretamente, precisam da linguagem humana para existir. Dito isso, pode-se inferir que quase tudo na civilização é subproduto da linguagem. História e literatura, por exemplo, são constituídas por meio da linguagem humana, que se configura como sua matéria-prima fundamental. Quanto à história, diz Raymond Boudon (1990, p. 173), ela possui "afinidades profundas" e certa convergência com a sociologia. A sociedade é documentada e analisada pelas duas disciplinas, e uma utiliza a outra para aprimorar suas investigações. $\mathrm{O}$ mesmo tipo de interação acontece entre literatura e sociologia e, se lembrarmos de Aristóteles, a interação entre literatura e história se dá no confronto dialético ficção-fato.

A literatura é um fenômeno humano, uma apropriação do mundo, um veículo de ideias, um produto cultural e histórico (FACINA, 2004). O ser humano e a sociedade são a inspiração e o meio em que a literatura é criada. Ou como Lukács (2009) afirma, não há arte sem realidade, objetiva ou subjetivamente, a arte é uma representação da realidade. Já o professor Raymond Williams (1977), também de veia marxista, classifica a literatura como uma reconstituição de práticas histórico-sociais. Na história encontramos acontecimentos, enquanto na literatura podemos encontrar desejos de homens em conflito com desejos de outros homens (LUKÁCS, [1955] 2011). Ademais, ela própria é parte integrante da sociedade e, portanto, as ciências sociais podem nos ajudar a "investigar as condições de sua produção, situando seus autores histórica e socialmente" (FACINA, 2004, p. 25), assim, elas facilitam o entendimento do contexto social em que uma obra literária é criada. 
Um dos principais fundamentos da história é o passado, e o passado é sobre perda, e perda é uma condição humana de acordo com Salman Rushdie (1991), que propõe que a literatura tem a missão de lutar contra a história, de desmentir as histórias ditas oficiais, pois história não é documento oficial, opinião que corrobora a de Nietzsche (2015). Literatura é um lugar para sociedades se autocriticarem e a literatura de imigrantes, área desta dissertação, é onde a modernidade pode ser interrogada (RUSHDIE, 1991).

Nesta investigação sobre Ham on Rye, a sociologia e a história permitem entender o período conturbado dos EUA no entre guerras do século passado (1919-1939), como a sociedade muda e como seus membros se comportam em tal época. Com este conhecimento, ser-nos-á possível fazer uma análise mais acurada sobre os processos de composição da obra e sobre como as representações nela encontradas questionam e problematizam a história dita 'oficial'. Outrossim, concordo com Lucien Goldmann quando afirma que "os verdadeiros objetos motivadores da criação cultural são os grupos sociais, e não os indivíduos isolados." (GOLDMANN, 1976, p. 4). À vista disso, acredito que um melhor entendimento de Ham on Rye e do contexto de sua produção nos possibilitará, futuramente, outros estudos de outras obras e de outros autores da mesma época.

Para tanto, examino como se dá a formação dos Estados, em especial os EUA, e do nacionalismo, com o auxílio de teóricos da sociologia interessados neste tópico como Stuart Hall, Hannah Arendt e Tim Cresswell. A nação precisa de comunhão e unidade entre os pertencentes a ela para que ela exista, justamente papel principal do nacionalismo. Em Ham on Rye, o protagonista ao ser marginalizado por conta de sua origem e classe, perceberá como o Estado trata desigualmente os indivíduos, fazendo com que ele questione a validade do nacionalismo. Ao operar em diferentes dimensões, desde a escola até a família, de esportes ao ‘sonho americano', o nacionalismo é desvendado por Henry Junior ao mesmo tempo em que este é descartado pela nação e seus integrantes.

Já no capítulo seguinte, adoto uma abordagem mais interna, investigando ao longo da narrativa a formação de identidade e o desenvolvimento da personalidade da personagem Henry Junior em face à sociedade que não o aceita, levando-o muitas vezes a não aceitar a si próprio. Portanto, neste capítulo, tanto o enfoque quanto o arcabouço teórico será psicanalítico. Não me cabe fazer um tratado sobre a ciência psicanalítica, mas sim me utilizar de abordagens específicas a fim de entender a construção da personagem Henry Junior. Para tal fim, dialogo com dois grandes autores da psicanálise mundial: Sigmund Freud e Carl Gustav Jung, sem deixar de interagir com outros críticos literários imbuídos e interessados no tema como Terry Eagleton e Ann Dobie. Além destes, procuro estabelecer ou mesmo 
descobrir e analisar os vínculos com outras abordagens. E por mais que talvez eles contestem e discordem uns dos outros, acredito que na verdade eles se complementam.

Por mais que o estudo da psique humana se constitua uma ciência relativamente jovem, seus avanços, concomitantemente com expansões de possibilidades de aplicação, têm feito da psicanálise uma ciência bastante influente para disciplinas humanas, mantendo-se, inclusive, relevante para os estudos literários ainda hoje. Em termos primários, psicanálise é a ciência que trata de entender de atitudes humanas, do porquê e de que maneiras o sujeito age. Ela lida com significados, ansiedades, identidades e a relação destas com cultura e sociedade. Para Jung ([1954] 1988, p. 84), o laboratório da psicologia é o mundo e o "homem [que] deve ser levado a adaptar-se [...] à família, profissão, sociedade [...] e às exigências vitais de sua própria natureza.” Portanto, ao analisar o sujeito, não há como não analisar o objeto.

Freud confessa em Totem e tabu ([1913] 2012) que a psicanálise possui uma visão unilateral em suas investigações, mas que, ao mesmo tempo, não reivindica exclusividade. $\mathrm{O}$ crítico literário Terry Eagleton ([1983] 1996, p. 153) alega: “[...] uma leitura psicanalítica de um romance [...] não precisa ser uma alternativa para uma interpretação social dele. Estamos falando de dois lados ou aspectos de uma singular situação humana."2 Estudando Freud, Eagleton ([1983] 1996) explica que o indivíduo é um produto de relações com outros indivíduos. Portanto, vê-se aqui uma ligação preliminar da psicanálise com sociologia. Em suma, a análise de aspectos psicanalíticos em Ham on Rye é um importante recorte para que eu possa encontrar respostas sobre a personagem Henry Junior e chegar a conclusões sobre o romance.

O professor John Lye (1996), da Brock University, atesta: "Psicanálise constitui um enfoque para questões sobre bem e o mal, [...] sofrimento e erro, as quais nos flagelam na condição de humanos."3 Considerando a obra literária como um reflexo do mundo concreto, pode-se afirmar que os tormentos sofridos por uma personagem podem ser similares aos dos leitores, ou vice-versa. Integrando esta ideia, a autora Ann Dobie (2002, p. 48) considera que a análise psicanalítica de romances não contribui em termos estéticos para a crítica literária, mas seu valor "está em dar aos leitores uma maneira de aprofundar o entendimento sobre temas que estiveram sempre presentes na literatura ocidental, temas de família, autoridade e

\footnotetext{
2 "a psychoanalytical reading of the novel [...] need not be an alternative to a social interpretation of it. We are speaking rather of two sides or aspects of a single human situation." Esta e demais traduções desta dissertação são minhas.

3 "Psychoanalysis constitutes one approach to the questions of good and evil, and especially of suffering and error, which plague us as humans."
} 
culpa"4, os quais se encontram extensamente representados na literatura, e mais precisamente no romance Ham on Rye.

Lye (1996) diz que literatura e psicanálise possuem laços em comum em termos de linguagem e narrativa. Ele afirma: "Psicanálise lida com motivos, especialmente escondidos ou disfarçados", podendo ajudar a crítica literária a esclarecer uma obra no "nível da escrita por si mesma e no nível da ação da personagem dentro do texto."6 (LYE, 1996). Complementando Lye, Eagleton ([1983] 1996) trabalha com quatro formas de abordagem psicológica em literatura: autor, conteúdo, construção formal e leitor. Mais importante do que saber o que se passava na cabeça de Charles Bukowski quando escreveu o romance, será avaliar as representações das atitudes de Henry Junior e a interação da personagem com a sociedade, que o articula como um sujeito psicologicamente displaçado, além de como esse displaçamento interno dialoga com o displaçamento externo.

Displaçamento, um neologismo ainda não dicionarizado em português, já foi utilizado pelos professores Cláudio Roberto Vieira Braga e Gláucia Renate Gonçalves em teses sobre deslocamento do sujeito e sentimento de não pertencimento. Displaçamento é uma tradução livre do inglês displacement; os tradutores Tomaz Tadeu da Silva e Guacira Lopes Louro do livro A identidade cultural na pós-modernidade de Stuart Hall (1999), preferiram se referir a este termo como "deslocamento e descentração". O vocábulo em inglês possui diferentes significados dependendo do campo científico que o utiliza. Sendo assim, para esta dissertação, o que quero dizer quando uso tal expressão é algo referente a movimento e mobilidade. Um sujeito displaçado está deslocado, não só física, mas também socialmente. Ao discorrer sobre o displaçamento interno, tenho a intenção de mostrar que o sujeito se sente marginalizado e por vezes aceita tal condição.

Por fim, no terceiro capítulo, faço, de forma dialética a conexão entre o displaçamento social e o interno. Se a interdisciplinaridade está presente nesta dissertação tanto no primeiro quanto no segundo capítulo, ela surge ainda mais forte no último, por mais que os capítulos contenham autores que discordem entre si. Por conseguinte, para produzir uma crítica literária dialética sobre Ham on Rye e chegar à conclusão deste estudo, valho-me de diversas interações: entre os capítulos, entre a obra e a sociedade, entre os diferentes conflitos presentes na obra, entre a personagem e o meio onde vive e finalmente, entre história,

\footnotetext{
4 "lies in giving readers away to deepen their understanding of themes that have always been present in Western literature, themes of family, authority, guilt."

5 "Psychoanalysis deals with motives, especially hidden or disguised."

6 "the level of the writing itself, and the level of character action within the text."
} 
sociologia e literatura. Para tanto, a abordagem teórica neste capítulo final engloba autores preocupados em entender a dialética histórico-materialista presente na literatura, e consequentemente na sociedade.

Converso principalmente com o filósofo György Lukács, de quem uso a teoria para analisar a composição do herói Henry Junior e de como a obra Ham on Rye pode se configurar em um romance histórico contemporâneo. Também me valendo de influências do pensador húngaro como Marx e Engels, e também de autores mais atuais que Lukács, estudo como se dá a articulação entre o displaçamento externo e o interno e de como e porque a personagem acaba por buscar refúgio na arte. Nessa rede de interações dialéticas, faz-se necessário pesquisar o conflito de classes, estranhamento, ideologia, política e fetichização.

Sobre a arte, Lukács $(2009$, p. 105) reitera: “A verdadeira arte [...] fornece sempre um quadro de conjunto da vida humana, representando-a no seu movimento, na sua evolução e desenvolvimento", respaldando o interesse desta dissertação em não desassociar arte da realidade, representação do que é representado. Conforme Hermenegildo Bastos (2011, p. 10), pela obra literária, temos acesso ao mundo, "o particular se universaliza" e conseguimos "produzir os nexos para os acontecimentos aparentemente vazios de sentido [...]." Assim sendo, analisando dialeticamente a exclusão sofrida pelo protagonista, busco chegar a uma universalização de tal sentimento para melhor interpretar o mundo concreto. O displaçamento, conceito preponderante deste estudo, é além de tudo um elemento de integração entre as abordagens teóricas sobre o romance Ham on Rye, e que guia as questões e análises, tanto sobre a obra literária e suas personagens, quanto do mundo concreto e do contexto histórico de que a obra se refere e de quando ela foi escrita. 


\section{TODOS CONTRA UM}

My spoon was bent so that if I wanted to eat I had to pick the spoon up with my right hand. If I picked it up with my left hand, the spoon bent away from my mouth. I wanted to pick the spoon up with my left hand.

(Henry Junior)

\subsection{Nação e nacionalismo}

A nação, como é comumente entendida, é uma formulação contemporânea. Tal agrupamento social vem acontecendo desde o século XIV, mas ganhou força a partir da Revolução Francesa. A nação não é um lugar, é um povo. Nicola Abbagnano pondera que um veio do outro: "[O] conceito de nação começou a formar-se a partir do conceito de povo [...]" (ABBAGNANO, 2007, p. 694). A verdade é que a nação não existe sem um povo e viceversa. A nação é um destino e o povo pertencente a ela é "constituído pela vontade comum" (ABBAGNANO, 2007, p. 694). Segundo Raymond Boudon, a nação opera fundando-se em "paixões, interesses e representações comuns, que impregnam os nacionais da convicção de terem um destino comum diferente do das outras nações.” (BOUDON, 1990, p. 173). Portanto, pode-se muito bem considerar a nação como uma forma de controle político que faz uso de ideais e ideologias.

Para problematizar esse conceito romantizado de nação, será útil iniciar a discussão com o trabalho de Benedict Anderson, Imagined Communities (2008). Neste livro, Anderson (2008, p. 6) define nação como "uma comunidade política imaginada"7 . Esse imaginário, na visão de Anderson, não é necessariamente pejorativo, mas uma forma de se alcançar uma comunhão entre os indivíduos pertencentes a uma determinada nação. Essa comunidade é, ao mesmo tempo, limitada, pois não há nação que englobe todo o planeta; e é também soberana, ao seguir os ideais da Revolução Francesa que iam contra os poderes divinos da aristocracia e que queriam garantir a liberdade da nação.

\footnotetext{
7 "an imagined political community."
} 
Um sentimento inerente à nação é o nacionalismo. Para Wilbur Zelinsky (1988, p. 1): "[N]acionalismo é a paixão reinante dos nossos tempos [...] que alimenta a energia que impulsiona o Estado-nação."8 De acordo com a filósofa política Hannah Arendt (1994, p. 234), o nacionalismo é "essencialmente a conquista do Estado através da nação." Para que exista a nação, deve haver um destino em comum e uma ligação fraternal entre seus indivíduos, e tal ligação é função do nacionalismo.

Anderson começa a analisar o nacionalismo conectando-o interessantemente com religiosidade. Com a chegada do Iluminismo, a religião tem a sua hegemonia questionada e desestabilizada, porém "o sofrimento de que em parte é composta, não desapareceu."9 (ANDERSON, 2008 p. 11). Sem o paraíso e sem a salvação, não há mais continuidade da vida, não existe um devir após a passagem do homem na terra. Tal perda precisa ser recuperada, e o é de certa forma, pelo nacionalismo. Já Arendt não trabalha a ideia de perda e recuperação, ela afirma que a "nação usurpou o lugar tradicional de Deus e da religião [...]." (ARENDT, 1994, p. 237). O que nos importa aqui é que ambos os pensadores concordam que o nacionalismo como articulação de poder substitui a religião enquanto detentor medular da ideologia dominante. O futuro em comum, o passado glorioso e o destino são pilares do nacionalismo e são paralelos a "grandes sistemas culturais que o precederam"10 (ANDERSON, 2008, p. 12), ou seja, as religiões.

Ao se utilizar de artes sacras e principalmente da língua, as grandes religiões conseguem se autopromover como instância superior para os súditos iletrados. A língua latina, por exemplo, era algo inalcançável para um plebeu cristão da Idade Média que falasse francês ou espanhol. A mudança de tal panorama, isto é, a perda de força da cristandade, começa a se dar com o advento e expansão do Capitalismo editorial após a invenção da prensa no século XV. Mais e mais livros, e posteriormente jornais e documentos para suprir a crescente burocracia, foram impressos em línguas vernáculas. Anderson insiste na questão da impressão como totem do nacionalismo. Com o desenvolvimento da tipografia, o livro impresso se torna praticamente a primeira mercadoria a ter produção em série. Para conseguir mais mercado, as editoras se estabelecem por toda a Europa, primeiramente publicando livros em Latim. Porém, com o esgotamento desse nicho e com a ascensão gradual da burguesia, uma classe falante de línguas locais exige a produção em línguas vernáculas, disseminandoas, e ao mesmo tempo, enfraquecendo o Latim. Como este é considerado uma língua sagrada,

\footnotetext{
8 "Nationalism is the reigning passion [...] what breeds the energy that drives the nation-state."

9 "suffering which belief in part is composed did not disappear."

10 "large cultural systems that preceded it."
} 
a competição com outras línguas fez com que houvesse um declínio na "comunidade imaginada da Cristandade"11 (ANDERSON, 1991, p. 42) e um crescimento de outras comunidades, como os falantes, e agora consumidores de línguas vernáculas.

Assim, as línguas vernáculas, ao serem instituídas como línguas nacionais, consequentemente ganham força. Havia "a convicção de que línguas eram [...] propriedade pessoal de grupos específicos [...] e esses grupos, imaginados como comunidades, tinham o direito ao seu lugar autônomo em uma fraternidade dos iguais."12 (ANDERSON, 1991, p. 84). Portanto, a língua serve ao incipiente nacionalismo como forma de vincular e unificar os cidadãos das futuras nações. Além disto, os críticos literários Terry Eagleton (1983) e Raymond Williams (1977) concordam que posteriormente a literatura, um produto da língua, serviu como construção do nacionalismo por meio do estabelecimento da 'tradição' da literatura nacional. Tradição é aqui entendida como uma expressão dos limites impostos pelas classes dominantes (WILLIAMS, 1977).

Corroborando a ideia de comunidades imaginadas, Stuart Hall afirma, em A identidade cultural na pós-modernidade, ao comentar um texto de Enoch Powell: "A vida das nações, da mesma forma que dos homens, é vivida, em grande parte, na imaginação [...]” (HALL, 1999, p. 51). Logo depois, Hall complementa: “[H]á a narrativa da nação [...] ela dá significado e importância à nossa monótona existência, conectando nossas vidas cotidianas com um destino nacional que preexiste a nós.” (HALL, 1999, p. 52). Posteriormente conclui: “[N]ão importa quão diferentes seus membros possam ser em termos de classe, gênero ou raça, uma cultura nacional busca unificá-los numa identidade cultural, para representá-los todos como pertencendo à mesma e grande família nacional." (HALL, 1999, p. 59). A família nacional então é unida por meio do nacionalismo, o qual é composto de um passado imaginário, um devir hipotético glorioso e uma língua em comum, agora utilizada inclusive pela Igreja, e que serve de amálgama entre todos os membros da nação. Por conseguinte, a nação não se sustenta sem nacionalismo e vice-versa, e por isso é de grande interesse dela a promoção e o enraizamento dos aspectos nacionais nos membros da nação.

\footnotetext{
11 "imagined community of Christendom."

12 "the conviction that languages were [...] the personal property of quite specific groups [...] and these groups, imagined as communities, were entitled to their autonomous place in a fraternity of equals."
} 


\subsection{Nacionalismo nos EUA}

Além do advento do Capitalismo editorial, outro fato histórico significativo influencia a construção do nacionalismo: a 'descoberta' das Américas, e subsequentemente, sua independência. As grandes navegações promovem um encontro com o pluralismo humano, com civilizações que se desenvolveram sem a filosofia grega, sem o direito romano, sem o cristianismo e sem a história e valores europeus. A colonização abre espaço para uma inicial problematização da Europa como centro do mundo.

Simultaneamente, a Revolução Francesa marca a eclosão de inúmeras mudanças para o ser humano e para a sociedade. Anderson (1983) nos recorda que com a Revolução Francesa, há a inclusão de história nas universidades pela primeira vez, algo que ideologicamente ajuda na construção e difusão do nacionalismo, pois "[c]omo poderia a história melhor servir à vida senão vinculando os povos e raças mais favorecidas à sua pátria e seus costumes nacionais, fixando-os e fazendo-os desistir de ir procurar e disputar em outros lugares melhores condições de vida?” (NIETZSCHE, 2015, p. 63). Contudo, há um evento que serve de inspiração para os revolucionários franceses e quase tão relevante quanto à própria Revolução Francesa para a história do nacionalismo: a Independência dos Estados Unidos da América.

A Declaração de Independência das treze colônias dos EUA, em 1776, é um fato com repercussão planetária, motivando outras colônias nas Américas e ao redor do globo a se libertarem de suas metrópoles europeias ao longo dos anos que seguem e um elemento fundamental para se entender a ideia de nação e também do nacionalismo. Não coincidentemente, dois personagens, um estadunidense e outro francês, participam das duas revoluções (TINDALL, 1984). Thomas Jefferson redigiu a declaração de independência e estava na França quando a revolução eclodiu, trabalhando como ministro e acompanhante de Marquês de Lafayette, político francês que lutara ao lado dos americanos na Guerra da Independência. Gordon S. Wood (2002, p. xxiii) escreve no prefácio de The American Revolution: "[A] Revolução convencera os americanos que eles eram um povo especial com um destino especial para liderar o mundo em direção à liberdade. A Revolução, em suma, deu à luz a qualquer senso de nacionalidade e de propósito nacional que os americanos tem." 13

\footnotetext{
13 "the Revolution had convinced Americans that they were a special people with a special destiny to lead the world toward liberty. The Revolution, in short, gave birth to whatever sense of nationhood and national purpose Americans have had."
} 
Pode-se constatar claramente como a revolução da independência da nação estadunidense passa a compor o imaginário do povo. Neste contexto, é valoroso notar que, segundo Anderson, o nacionalismo nasceu no novo e não no velho mundo, mais precisamente nessa "comunidade imaginada" chamada de Estados Unidos da América. Por isso seus ideais, aspirações e contradições representadas em Ham on Rye merecem uma análise mais aprofundada.

\subsection{Making America, a cultura nacional em construção nos EUA}

Discorrer sobre os EUA requer um comentário prévio que trate cultura nacional e identidade cultural concomitantemente. Sobre isto, Hall (1999, p. 47) avalia: "No mundo moderno, as culturas nacionais em que nascemos se constituem em uma das principais fontes de identidade cultural". E complementa no texto Cultural Identity and Diaspora: "[C]ultura nacional é todo um conjunto de esforços feito por um povo na esfera do pensamento para descrever, justificar e enaltecer a ação pela qual tal povo criou a si mesmo e se mantém existente." ${ }^{\prime 14}$ (HALL, 1990, p. 237). Isso se apresenta de forma própria nos EUA pelo fato deles serem do novo mundo, possuindo então uma história diferente das nações europeias. As nações do velho mundo recorrem ao passado e à tradição, às vezes inventadas, para construir a narrativa do Estado-nação. Um exemplo dado por Anderson (1991) é o estabelecimento em 1891 da data de fundação da Suíça como 1281.

Mas como fazer isso numa república recém-nascida sem passado e formada por uma população multiétnica? E "o que americanos tinham em comum senão o fato de terem vindo de diferentes ancestrais?"15 (MANN, 1987, p. 68). Para se responder a essas questões, devese levar em conta que os Estados Unidos da América são o país que mais recebeu imigrantes na história recente, vindos de diferentes países e por diferentes razões. Eles também são a primeira nação a criar leis para controle e naturalização de imigrantes (MANN, 1987). O interesse inicial dos EUA é muito claro: ao fim da Guerra da Independência, o país era pouco populoso e com um imenso potencial para expansão territorial. Os imigrantes, portanto,

\footnotetext{
14 "national culture is the whole body of efforts made by a people in the sphere of thought to describe, justify and praise the action through which that people has created itself and keeps itself in existence."

15 "What therefore did the Americans have in common other than the fact that they sprang from different ancestors?"
} 
ajudariam o recém-criado país a crescer e a se desenvolver. Ao contrário de nações europeias, que concebem seus discursos de nação baseados em herança natural, o novo país inclui imigrantes na construção da ideia de nação.

A noção do imigrante como parte do mito de fundação de uma nação legitima um pluralismo cultural, envolvendo religiões, costumes e valores junto com o imigrante; e o desejo de um novo começo e de prosperidade passa a moldar a ideia da nação dos EUA. Tais valores corroboram a criação de uma suposta comunhão entre os cidadãos e os novos imigrantes, algo que não acontece na Europa, onde prevalece um discurso de nação caracterizado por uma hipotética pureza de seus indivíduos.

A constatação do imigrante em mito fundacional dos EUA corrobora a noção de Hall de que "a nação é algo que produz sentidos - um sistema de representação cultural." (HALL, 1999, p. 49). Portanto, ‘ser americano’ é parte de uma representação cultural na qual cidadãos participam da ideia de nação. Cabe observar que Hall se utiliza de exemplos europeus, em especial da Inglaterra, para definir culturas nacionais e é importante insistir que os EUA constroem seu nacionalismo diferentemente das nações do Velho Mundo, pois não possuem a história das mesmas, não podendo, consequentemente, recorrer ao passado. De qualquer maneira, esta afirmativa de Hall é útil para estudarmos a formação peculiar de identidade cultural e nacional estadunidense.

Hall (1999, p. 48) também afirma que "as identidades nacionais não são coisas com as quais nós nascemos, mas são formadas e transformadas no interior da representação.” O ponto crucial em Hall, para este trabalho, é o que concerne à construção da identidade: “As culturas nacionais, ao produzirem sentidos sobre a nação, sentidos com os quais podemos nos identificar, constroem identidades [...]" (HALL, 1999, p. 51). O indivíduo consegue agir autonomamente somente porque se sente pertencente a um grupo. Entretanto, a personagem principal de Ham on Rye questiona: o que acontece quando não há a prometida integração? $\mathrm{O}$ que ocorre com um imigrante que deveria fazer parte da nação, mas que é alijado da formação de grupos e da própria nação? 


\subsection{Xenofobia contra os alemães nos EUA}

Para se responder a pergunta acima e para fundamentar esta pesquisa, faz-se necessário levar em conta alguns fatores históricos. Primeiramente, algumas contradições nascem com a fundação da nação estadunidense. Mesmo que "a América tenha sempre sido uma terra de imigrantes" $" 16$ (TINDALL, 1984, p. 455) e que os estrangeiros ajudem a desenvolver o país e participem na criação da nação, os descendentes de anglo-saxões e nórdicos, se autointitulam 'nativos'. De maioria protestante, eles passam a se preocupar com a presença de tantos imigrantes católicos, principalmente irlandeses e alemães (TINDALL, 1984). A competição nos negócios também preocupa, por mais que imigração seja peça fundamental para o crescimento econômico do país.

Em cerca de 60 anos de existência como nação independente, os EUA, na década de 1840, começam a ter os primeiros movimentos anti-imigração. Nasce o nativismo estadunidense, um movimento xenofóbico que cresce com a Guerra de Secessão (1861-65) no século XIX e posteriormente, com as Guerras Mundiais no século XX, servindo-se em algumas ocasiões de teorias eugenistas da época (BONDI, 1996). O entre guerras do século passado (1919-1939), por sinal, é o período em que vive a personagem central de Ham on Rye, Henry Chinaski Junior, um imigrante alemão morando nos EUA que sofre com o forte sentimento antigermânico da época.

Henry Junior parece representar literariamente a trajetória de milhares de alemães. A imigração germânica para os EUA começa em meados do século XVII, antes mesmo da criação da Alemanha ou mesmo da independência dos Estados Unidos da América, e não cessa desde então. De acordo com a página eletrônica da Biblioteca do Congresso dos Estados Unidos da América, mais de 58 milhões de estadunidenses são de descendência alemã, segundo censo de $1990^{17}$, constituindo a maioria da população do país. As imigrações alemãs foram motivadas por diferentes razões: ausência de liberdade religiosa, perda de liberdade política, fuga de guerras na terra natal e oportunidades de trabalho na terra anfitriã.

Por migrarem em grande quantidade e por causa de seus costumes, os alemães são uns dos principais alvos dos nativistas. A maioria dos alemães que imigram é católica e estão num país de predominância protestante. O idioma diferente também incomoda, uma vez que o Estado-nação deseja que uma língua única, o inglês nos EUA, seja a amálgama que una os

\footnotetext{
16 "America had always been a land of immigrants."

${ }^{17}$ Disponível em: <http://www.loc.gov/rr/european/imde/germchro.html>. Acesso em 05 de junho de 2015.
} 
seus membros. Ademais, grande parte dos imigrantes alemães são profissionais estudados e experientes (TINDALL, 1984) e vêm para trabalhar com comércio, passando então a ser encarados como ameaça para os comerciantes estadunidenses já estabelecidos.

Vemo-nos diante de um jogo de poder de dominantes contra dominados no qual o grupo subjugado não é necessariamente uma minoria numérica como nos lembra Boudon (1990). Para a sociologia, um grupo de pessoas em maior quantidade, contudo, rejeitadas socialmente podem se configurar em minoria, o que leva Avtar Brah a problematizar a noção de minoria e de maioria: “"Minorias' são posicionadas em relação não somente a 'maioria', mas também a outras "minorias'." (BRAH, 1996, p. 189). Ou seja, o discurso de minorias é definido em termos políticos, baseado em dominação ideológica e manipulação social (BRAH, 1996) pelos detentores do poder. Um exemplo conhecido são os negros subjugados na África do Sul (BOUDON, 1990), ou, neste caso, os alemães nos EUA em meados do século passado.

A despeito de serem tidos como ameaça contra os 'tradicionais ideais americanos', os imigrantes alemães e respectivos descendentes conseguem viver e se adaptar à cultura americana com relativa liberdade, podendo falar sua própria língua dentro de comunidades germânicas, criando escolas próprias, e também, editando jornais e revistas publicados em língua germânica, chegando ao relevante número de 800 edições em alemão no ano de $1894^{18}$.

Porém, tudo muda para os residentes alemães com a Primeira Grande Guerra (19141919). A partir da entrada dos EUA no conflito em 1915, uma histeria antigermânica tem início no país resultando em leis e ações governamentais que põem fim a nomes de ruas, fecham igrejas, pró́bem música de compositores alemães nas rádios, publicações alemãs, e que obrigam o uso da língua inglesa em todas as escolas públicas e privadas (BAUGHMAN, 1996). Essa histeria causa traumas e também acelera a assimilação dos alemães na cultura americana, tendo influências diretas na construção da identidade nacional dos indivíduos.

\subsection{Identidade nacional em Ham on Rye}

Em Ham on Rye, Charles Bukowski aborda uma série de fatores que influenciam a formação da identidade nacional tais como: língua, etnia, lealdade à pátria, nacionalismo e

\footnotetext{
${ }^{18}$ Disponível em: <http://usa.usembassy.de/>. Acesso em 03 de Junho de 2015.
} 
preconceito. A questão linguística que, conforme visto, é diretamente ligada à identidade da nação, é abordada de forma sutil no primeiro capítulo de Ham on Rye em que o protagonista narrador Henry Junior começa a descrever suas primeiras memórias do início da década de 1920, as quais ele não sabe ao certo onde se passam, se na Alemanha ou nos EUA. Ao falar da família, ele recorda: "Essas pessoas falavam alemão na maior parte do tempo e no começo eu também falava."19 (BUKOWSKI, 1982, p. 2). Observa-se que o espaço físico é suplantado pela língua alemã em um ambiente familiar, sendo que ambos figuram como parte da construção da memória da personagem em termos de identidade nacional. Posteriormente, quando Henry Junior não mais coloca em dúvida onde se encontra, a família Chinaski abandona o uso da língua mãe, podendo caracterizar uma referência às novas e agressivas políticas estadunidenses de assimilação contra alemães instalados nos EUA. Uma vez na 'América', deveriam se aculturar e falar inglês.

O período entre guerras, contexto histórico do romance, é uma época de intensa hostilidade contra os descendentes germânicos, conforme discutido. Um exemplo disto no romance é a antipatia dos vizinhos de mesma idade do jovem Henry Junior. Ao descobrirem que ele é alemão, começam a maltratá-lo, como na seguinte passagem: “"Ei, Heinie ${ }^{20}$ 'eles gritavam, 'Por que não volta pra Alemanha? [...] Ei, Heinie, volte para a Krautland!',21 (BUKOWSKI, 1982, p. 59). Nesta passagem, o leitor é convidado a refletir sobre uma discriminação representada na narrativa que não envolve a cor da pele ou a língua falada. Mesmo já falando inglês e não tendo diferenças físicas consideráveis com os garotos brancos, Henry Junior sente ao seu redor a existência de uma comunidade imaginada que não parece tê-lo incluído por causa de sua terra natal, situação que leva a personagem questionar a lealdade à sua nova pátria.

Mais adiante, Henry Junior faz amizade pela primeira vez na vida, com Frank. Quando faz referências às revistas $p u l p^{22}$ sobre a I Grande Guerra que o amigo o empresta, Henry Junior apresenta um início de identificação com a sua origem alemã:

Frank gostava de aviões. Ele me emprestou todas as suas revistas pulp sobre a Primeira Guerra. A melhor era Flying Aces. As dogfights eram demais, os

\footnotetext{
19 "These people spoke German mostof the time and in the beginning I did too."

20 "Heinie" era uma forma pejorativa de se chamar alemães nos EUA no início do século passado. Heinie é um apelido para Heinrich, ou Henry nos EUA, um nome muito comum para alemães e descendentes (The British Library. Disponível em: <http://www.bl.uk/world-war-one/articles/slang-terms-at-the-front>). Acesso em 25/09/2015.

21 “'Hey, Heinie!' they yelled, 'Why don't you go back to Germany? [...] Hey, Heinie, go back to Krautland!'”

${ }^{22}$ Revistas baratas com histórias de ficção, muito populares nos EUA nas primeiras décadas do século XX (The Library of Congress of the USA. Disponível em: <http://www.loc.gov/rr/news/pulp.html>). Acesso em 25/09/2015.
} 
Spads e os Fokkers se misturando. Eu li todas as histórias. Eu não gostava do jeito que os alemães sempre perdiam, mas tirando isso era demais. ${ }^{23}$ (BUKOWSKI, 1982, p. 76)

Em outra passagem, quando Henry Junior está a lembrar de sua infância, ele se recorda de uma luta de boxe que faz parte da história esportiva estadunidense e um símbolo da tensão da época entre os EUA e a Alemanha, a disputa que mobilizou os dois países entre o estadunidense Joe Louis e o alemão Max Schemeling (ERENBERG, 2006): “Quando eu era criança e Max Schmeling nocauteou Joe Louis, eu corri para as ruas procurando pelos caras gritando 'Ei, Max Schemeling nocauteou Joe Louis!' e ninguém me respondeu, ninguém disse nada, eles apenas foram embora com cabeças baixas." 24 (BUKOWSKI, 1982, p. 316). Percebe-se como o displaçamento da personagem ainda criança começa a influenciar seu imaginário. Henry Junior é um garoto normal até certo ponto, pois gosta de aviões, brinca com os amiguinhos e acompanha esportes. Porém, a discriminação sofrida e sua origem germânica são forças que estabelecem parâmetros para a construção de sua identidade. O laço fraternal imaginado que teoricamente teria com os indivíduos estadunidenses está rompido, e, como forma de compensação, ele o articula com sua distante e antiga nação. Ao ler as revistinhas sobre a I Guerra e acompanhar uma importante luta entre um estadunidense e um alemão, ele se identifica com os alemães, assumindo inconscientemente o papel do 'outro' na sociedade americana. E identificar-se com a origem alemã num contexto entre guerras é problemático, pois acentua o isolamento social e o rompimento dos laços nacionalistas.

Futuramente, no ensino médio, Henry Junior entra para o treinamento de cadetes da reserva para escapar das aulas de educação física. Uma vez lá, ele se depara com alunos obrigados a participar do regimento porque os pais consideravam patriótico ter filhos em tal grupo. Então, a personagem pondera sobre questões nacionalistas estadunidenses:

Os pais dos garotos ricos tendiam ser mais patrióticos porque tinham mais a perder se o país fosse derrotado. Os pais pobres eram bem menos patrióticos, e eles frequentemente professavam seu patriotismo somente porque era esperado ou por causa da forma que foram criados. Subconscientemente eles sabiam que não seria nem melhor nem pior para eles se Russos, Alemães,

\footnotetext{
23 "Frank liked airplanes. He lent me all his pulp magazines about World War 1. The best was Flying Aces. The dog-fights were great, the Spads and the Fokkers mixing it. I read all the stories. I didn't like the way the Germans always lost but outside of that it was great."

24 "When I was a kid and Max Schmeling K.O.'d Joe Louis, I had run out into the street looking for my buddies, yelling 'Hey, Max Schmeling K.O.'d Joe Louis!' and nobody answered me, nobody said anything, they had just walked away with their heads down."
} 
Chineses ou Japoneses governassem o país, principalmente se tivessem pele escura. As coisas poderiam até melhorar. ${ }^{25}$ (BUKOWSKI, 1982, p. 187)

Em tom irônico, Henry Junior já mostra sinais de uma percepção ampliada. O amor à terra e lealdade à nação é algo ligado aos bens materiais ou à uma educação imposta, não algo natural; mas, por hipocrisia e medo, ninguém falava sobre isso. No caso dos ricos, o amor à pátria sugere uma lealdade ao sucesso financeiro provido pela nação, já no caso dos pobres, o patriotismo é um comportamento automatizado, que por desconhecimento ou receio, não é questionado.

Há mais amostras de não pertencimento por parte de Henry Junior à comunidade imaginada dos EUA. Por exemplo, logo depois de terminar o ensino médio, passa a procurar uma colocação no mercado de trabalho, assim como outros jovens, quando a questão da sua origem germânica é retomada:

Procurei emprego o verão todo e não pude achar um. Jimmy Hatcher conseguiu um numa fábrica de aviões. Hitler estava agindo na Europa e criando empregos para os desempregados. Eu estive com Jimmy naquele dia quando entregamos nossas fichas de inscrição. Nós as preenchemos da mesma forma, a única diferença era onde dizia Local de Nascimento, eu coloquei Alemanha e ele colocou Reading, $\mathrm{Pa}^{26}$ (BUKOWSKI, 1982, p. 245)

Conseguir um emprego é indispensável na vida de um jovem estadunidense, em particular no período pós-Grande Depressão, e Henry Junior sente-se impedido de participar disto por causa de sua procedência. A discriminação sofrida parece ampliar a identificação da personagem com sua origem germânica. Contudo, ela vai adquirindo uma forma de contraataque à não aceitação. Henry Junior, quase ao fim da narrativa, está na Faculdade de Jornalismo. A Segunda Grande Guerra (1939-1945) já havia começado, mas os EUA ainda não haviam tomado partido, e a personagem então descreve o ambiente predominante na esfera pública em contraste com o que se passa com ele:

Era intelectualmente popular e apropriado ser a favor da guerra contra a Alemanha, para parar a propagação do fascismo. Para mim, eu não tinha desejo algum de ir à guerra para proteger a vida que tinha ou o futuro que

\footnotetext{
25 "The parents of rich kids tended to be more patriotic because they had more to lose if the country went under. The poor parents were far less patriotic, and then often professed their patriotism only because it was expected or because it was the way they had been raised. Subconsciously they knew it wouldn't be any better or worse for them if the Russians or the Germans or the Chinese or the Japanese ran the country, especially if they had dark skin. Things might even improve."

26 "I looked for a job all summer and couldn't find one. Jimmy Hatcher caught one at an aircraft plant.Hitler was acting up in Europe and creating jobs for the unemployed. I had been with Jimmy that day when we had turned in our applications. We filled them out in similar fashion, the only difference being where it said Place of Birth, I put down Germany and he put down Reading, Pa."
} 
poderia ter. Eu não tinha liberdade. Eu não tinha nada. Com Hitler por aqui, talvez eu até conseguisse comer alguém de vez em quando e mais do que um dólar de mesada por semana. Até onde eu pudesse racionalizar, não havia nada para proteger. Também, tendo nascido na Alemanha, havia uma certa lealdade e eu não gostava de ver toda a nação alemã, as pessoas, sendo sempre retratadas como monstros e idiotas. ${ }^{27}$ (BUKOWSKI, 1982, p. 262)

A personagem incute que discursos pró-guerra e antifascismo são repetições acríticas oriundas de um sentimento nacionalista artificial. A disseminação de discurso nacionalista baseada na construção de um inimigo em comum não recebe afinidade alguma do protagonista. Como forma de demonstrar desapego à moda antinazista, Henry Junior começa a proferir discursos pró-nazista ao redor do campus da LA City College, chamando atenção de alguns transeuntes. Ele, porém, esclarece: "Eu evitava quaisquer referências a negros e judeus, que jamais haviam me dado problemas. Meus problemas vieram todos de gentios brancos." 28 (BUKOWSKI, 1982, p. 263). Seus discursos não eram exatamente uma aliança à ideologia de Hitler, mas sim uma forma proposital de se afastar das pessoas medianas com opiniões pré-moldadas que o discriminavam. Como ele mesmo afirma: "Eu não era nazista por temperamento ou escolha; os professores mais ou menos forçaram aquilo em mim por serem tão iguais e pensarem tão igual e com seu preconceito antialemão." ${ }^{\text {„29 }}$ (BUKOWSKI, 1982, p. 263). Como Russel Harrison analisa em Against the American Dream: Essays on Charles Bukowski (1994), Henry Junior consegue uma resposta positiva por parte de certos alunos, trazendo-o uma sensação rara de pertencimento, algo que busca e não consegue na infância.

Os discursos da personagem, somados à origem alemã, chamam a atenção do Partido Nazista de Los Angeles. Na realidade, mesmo com os horrores da guerra na Europa e o apoio aos aliados por parte dos EUA, o movimento nazista possui representação no território estadunidense: "Na realidade histórica, grandes parcelas da nação sempre mantiveram simpatias constantes ou flutuantes por um lado ou outro." (LUKÁCS, [1955] 2011, p. 54). Por exemplo, o German-American Bund, maior partido nazista dos EUA chega a ter vinte e cinco

\footnotetext{
27 "It was intellectually popular and proper to be for going to war with Germany, to stop the spread of fascism. As for me, I had no desire to go to war to protect the life I had or what future I might have. I had no Freedom. I had nothing. With Hitler around, maybe I'd even get a piece of ass now and then and more than a dollar a week allowance. As far as I could rationalize, I had nothing to protect. Also, having been born in Germany, there was a natural loyalty and I didn't like to see the whole German nation, the people, depicted everywhere as monsters and idiots."

28 "I avoided any direct reference to Jews and Blacks, who had never given me any trouble. All my troubles had come from white gentiles."

29 "I wasn't a nazi by temperament or choice; the teachers more or less forced it on me by being so much alike and thinking so much alike and with their anti-German prejudice."
} 
mil membros em seu auge (BONDI, 1996). Tal fato não escapa a Charles Bukowski. De volta ao romance, Henry Junior frequenta uma das reuniões do partido nazista a título de curiosidade, porém já no começo do evento, durante o juramento a bandeira americana ele pensa: "Meu deus, estou no lugar errado!"30 (BUKOWSKI, 1982, p. 266). A curiosidade da personagem não está ligada a movimento algum, mas sim motivada por uma vontade de entendimento da vida ou de participar de algo (HARRISON, 1994). Assim sendo, ao desprezar os pertencentes do movimento, descrevendo-os como "mental e fisicamente aleijados”31 (BUKOWSKI, 1982, p. 265), Henry Junior está definitivamente isolado, não encontrando pertencimento no país-hospedeiro, tampouco nos defensores do regime do país onde nascera.

O tema guerra, da forma como é tratado ao final de Ham on Rye, remete a Anderson (1991, p. 141), que assegura que não há nada mais nacionalista do que morrer pelo próprio país: "[N]ações inspiram amor, e frequentemente um amor de autossacrifício" tempo em que podem provocar medo e repúdio contra o 'outro'. Bukowski retrata um elemento contraditório dos EUA por meio de sua personagem. Os EUA são o país dos imigrantes e a 'terra da liberdade e da oportunidade' quando lhes convêm, como por exemplo, quando há guerra, momento no qual se faz necessária união em termos ideológicos, para apoio popular à guerra, e para obter recrutas para lutarem no front. Ora, uma vez que Henry Junior não é aceito como um membro da nação 'americana', e é até mesmo alvo de repúdio pelos 'americanos', o sentimento nacionalista não é inspirado nele, nem mesmo em um momento tão intenso como a guerra, que é capaz de despertar manifestações nacionalistas extremas.

Como consequências desse sentimento patriótico não desenvolvido, Henry Junior é excluído ao mesmo tempo em que adquire uma percepção mais ampliada. No capítulo final, os EUA finalmente entram na guerra após o porto de Pearl Harbor ser bombardeado (1941). No exato momento em que é anunciado nas rádios que os EUA estão em guerra, Henry Junior está em um bar com seu único amigo de faculdade, Becker, um soldado da marinha. Ele analisa a reação dos fregueses do bar: "Os outros poucos clientes estavam tagarelando loucamente sobre Pearl Harbor. Antes, não falariam uns com os outros. Agora estavam mobilizados. A Tribo estava em perigo."33 (BUKOWSKI, 1982, p. 314). Ao observar o uso da

\footnotetext{
30 "My god, I thought, I am in the wrong place!"

31 "mental e physical cripples."

32 "nations inspire love, and often profoundly self-sacrificing love."

33 "The other few customers were babbling wildly about Pearl Harbor. Before, they wouldn't speak to each other. Now they were mobilized. The Tribe was in danger."
} 
palavra "tribo", é conveniente citar mais uma vez Hall (1999, p. 49): "A lealdade e a identificação que, numa era pré-moderna ou em sociedades mais tradicionais, eram dadas à tribo, ao povo, à religião e a região, foram transferidas, gradualmente, nas sociedades ocidentais, à cultura nacional.” A lealdade e a identificação mencionadas por Hall são incitadas por um grave bombardeio. Porém, Henry Junior, já consciente sobre a questão do nacionalismo, percebe que a identificação dos indivíduos com a nação é frágil, superficial e, de certo modo, inventada, induzida pela criação de um inimigo externo comum. Vale salientar que tanto os EUA quanto seus rivais socialistas russos e a inimiga Alemanha nazista se utilizam igualmente das propagandas de guerra como forma de impelir e manipular a consciência nacionalista (BONDI, 1996) nos indivíduos. Logo, a guerra articula o nacionalismo de maneira eficiente seja em quaisquer nações sob quaisquer regimes políticos.

Destarte, é possível observar que Henry Junior apresenta uma identidade nacional fragmentada e conflitante ao longo da narrativa. O país de nascimento é apenas um dos vários fatores que estão emaranhados na constituição da identidade nacional e cultural de um indivíduo, e a personagem em questão se encontra em um embate entre sua origem e a nação onde vive, provocando um displaçamento social. Ainda referente à identidade, Brah (1996, p. 195) pondera que "identidade é sempre plural e em processo, mesmo quando parece ser construída ou representada como fixa [...] ${ }^{, 34}$. Os EUA configuram, portanto, um espaço onde pertencimento e exclusão são contestados (BRAH, 1996) e neste contexto, Henry Junior juntamente com os outros alemães e respectivos descendentes, mesmo constituindo a maioria dos estadunidenses, num contexto de guerra, passam a ser categorizados como 'estranhos' e tratados como 'minoria' por não atenderem ao modelo dominante.

Nesta contraposição entre o individual e a coletividade em Ham on Rye, é possível enxergar uma inicial visão nietzschiana sobre a articulação do estado a fim de controlar os sujeitos: “[A] nacionalidade é frequentemente apenas a consequência de medidas rígidas pelas quais os homens são governados, quer dizer, encerrados numa classe, vigiados, postos no bom caminho, com a obrigação de se casar, falar e viver juntos." (NIETZSCHE, 2015, p. 153). A comunhão fraternal entre os integrantes da nação e desejada por esta, discutida por Anderson, assim como a lealdade citada por Hall, não são sentidas por Henry Junior, pois ele é o 'outro', é a fonte de contaminação da pureza de uma nação. Essa condição displaçada, acentuada pela hostilidade sofrida pela sua origem e à estranheza que isto causa nos indivíduos, faz com que a personagem repudie ser encerrado pelo nacionalismo americano,

\footnotetext{
34 "identity is always plural and in process, even when it might be constructed or represented as fixed."
} 
ignorando seus valores, afastando-se dos ideais da nação onde vive, e, consequentemente, de seus cidadãos.

\subsection{Esportes como símbolos na construção do nacionalismo estadunidense}

Se para a manutenção da nação o nacionalismo é primordial, para que este exista, uma série de fatores, sentimentos e símbolos devem ser alimentados nos indivíduos para se alcançar a coletividade fraternal que a nação deseja. Conforme visto acima, a propaganda de guerra é uma das estratégias da nação que visa mobilizar os indivíduos em prol da coletividade. E nesta seção trabalho com outro apelo simbólico comum entre às nações, o esporte nacional.

Assim como a religião se baseia num sistema abstrato e simbólico, a sua sucessora, o nacionalismo, possui um complexo e organizado sistema de símbolos, uma 'mitologia' própria que fornece uma "representação da natureza, significado do mundo e o lugar de um indivíduo no mesmo [...]”35 (ZELINSKY, 1988, p. 14). Segundo o teórico político Michael Walzer (WALZER apud ZELINSKY, 1988 p. 15): “[O] Estado é invisível; tem de ser personificado antes de ser visto, simbolizado antes de poder ser amado, imaginado antes de poder ser concebido. ${ }^{36}$ Deparamos-nos mais uma vez com o imaginário sendo utilizado como articulação de poder.

Parte do sistema de símbolos do nacionalismo, os esportes são estratégicos para situar o sujeito na sociedade estadunidense, seja como praticante ou como espectador. Analisando o caso dos EUA, Richard G. Powers (1988, p. 217) pondera: "Esportes são um espelho da vida americana [...] Eles podem ser vistos como um esforço da cultura americana em construir uma alternativa imaginativa à realidade consciente [...]"37 e continua em seguida: "[C]ultura de esportes tem um mecanismo para ajudar indivíduos a se identificarem com o grupo, substituindo sua solidão por uma segurança de pertencimento."38 (POWERS, 1988, p. 217). Portanto, pode-se dizer que o esporte moderno é uma atividade social que gera uma força

\footnotetext{
35 "depiction of the nature and meaning of the world and one's place in it".

36 "the state is invisible; it must be personified before it can be seen, symbolized before it can be loved, imagined before it can be conceived."

37 "Sports are a mirror of American life [...] They can be viewed as American culture's effort to construct an imaginative alternative to conscious reality."

38 "sports culture has its mechanism for helping individuals identify with the group, for replacing their loneliness with security of belonging."
} 
integradora e fraternal dentro da comunidade. Têm-se os esportistas, substitutos modernos de um exército (ZELINSKY, 1988), e também há os espectadores, em uma comunhão quase que religiosa, a torcer pelos times.

Ao discorrer sobre esportes na modernidade, sua relação com a política e a formação da identidade cultural nos EUA, é impossível não falar de beisebol e futebol americano, os dois esportes mais cultuados, lucrativos e emblemáticos do país. Apesar de terem antecedentes britânicos, ambos são considerados esportes nacionais e estão ligados à ideia de 'americanidade', sendo praticados por pessoas de todas as idades e com notórios campeonatos profissionais. Enquanto a popularidade do beisebol tem ligação cerebral com o crescimento urbano nos EUA e o seu racionalismo (ZELINSKY, 1988), o futebol americano é o esporte mais tribal (POWERS, 1988) e tem ligação com a "alma nacional, talvez por causa de sua combinação de agressividade, territorialidade, e interação fluída entre comunidade e individualidade." ${ }^{\text {"39 }}$ (ZELINSKY, 1988, p. 111). Tendo em vista a popularidade e a relevância de tais esportes nos EUA, eles estão presentes em Ham on Rye e se relacionam com a construção de identidade de Henry Junior.

Ainda criança, o protagonista se vê proibido pelo pai de jogar beisebol com as crianças da rua, e na escola, ele é também, a princípio, rejeitado. O mesmo acontece com futebol americano em uma das primeiras tentativas de jogar o esporte. Nunca tendo praticado, ele não sabe jogar: é expulso após uma falta e transferido para o time de voleibol. Henry Junior então reflete: “[...] os outros estavam jogando futebol. Eu queria jogar futebol. Tudo que eu precisava era um pouco de prática. Voleibol era vergonhoso." ${ }^{40}$ (BUKOWSKI, 1982, p. 28). Verifica-se uma vontade de pertencimento ao grupo dos outros rapazes, motivada pelo esporte nacional. Considero que Bukowski quer representar a constituição de grupos como instrumento de inclusão e pertencimento no imaginário infantil. O que o protagonista inicialmente quer é não ser o 'outro', e para isso aceita o que lhe é imposto socialmente: que voleibol era de alguma forma uma atividade para os meninos excluídos. Fazer parte da turma dos 'valentões' e fortes de certa forma o faria ser como eles: forte.

Henry Junior sofre frequentemente a ausência de vínculos com os seus pares via esportes, como por exemplo, na passagem em que em uma das primeiras vezes que tenta jogar beisebol com os colegas da escola, o próprio juiz não o aceita no jogo e o expulsa mesmo a

\footnotetext{
39 "national soul, perhaps because of its combination of aggressiveness, territoriality, and fluid interplay between community and individualism."

40 "the others were playing football. I wanted to play football. All I needed was a little practice. Volleyball was shameful."
} 
personagem tendo feito uma jogada legal: “'VOCÊ ESTÁ FORA!’ gritou o árbitro. Daí eu sabia que eu não era aceito. David e eu não éramos aceitos. Os outros me queriam fora porque eu deveria estar 'fora'."41 (BUKOWSKI, 1982, p. 27). Henry Junior culpa seu amigo David por ser expulso do jogo: "Eles sabiam que David e eu erámos amigos. Foi por causa de David que eu não era bem quisto." 42 (BUKOWSKI, 1982, p. 27). Nota-se que a personagem tenta se incluir socialmente por meio de um esporte nacional e há uma fratura quando nem colegas nem juiz o aceitam. Sem conseguir lidar com esta situação, Henry Junior projeta a própria exclusão e faz justamente o que é feito com ele: exclui o seu amigo. A formação de grupos por meio do esporte na cultura dos EUA é representada no romance como um jogo de poder entre ditos 'fortes' e 'fracos'. Os garotos se dividem entre fortes e fracos, e somente aos fortes é permitida a prática do esporte nacional, e metonimicamente, de fazerem parte da nação.

Nos capítulos que descrevem os primeiros anos escolares, apesar de Henry Junior ser sempre rejeitado, ele sistematicamente tenta se inserir, configurando um conflito interno na personagem; faz referências orgulhosas aos times da escola utilizando "nós" diversas vezes; somente no capítulo 21 do livro, quando um campeonato interescolar acontece, mesmo Henry Junior sendo apenas um espectador, ele se refere ao time da escola como "nós" por dezoito vezes (BUKOWSKI, 1982) evidenciando uma vontade inconsciente de inclusão. Apesar de toda a perseguição sofrida pela personagem e o resultante sentimento de displaçamento, ela ainda deseja fazer parte e interagir com o grupo.

Devido ao esporte, ironicamente, a personagem consegue um dos primeiros amigos de sua vida, um vizinho sem braço e por isso também discriminado, e concomitantemente uma das primeiras oportunidades de praticar futebol: "Tudo que um cara precisava era uma chance. Alguém estava sempre controlando quem tinha chance e quem não tinha." (BUKOWSKI, 1982, p. 61). Por causa de sua nova atividade esportiva, ele finalmente alcança alguma prática e com isto, mais autoconfiança. Ele até se sente forte o bastante para junto com Red afugentar um bando de garotos que os assediam.

Sentindo-se mais seguro de si, Henry Junior finalmente interage com os outros meninos da rua, alcançando um inicial senso de pertencimento. Porém, o pai o proíbe de jogar futebol na rua aos sábados, interrompendo sua atividade esportiva e sua interação social tão duramente conquistada. Mais adiante, a própria personagem se distancia das pessoas e

\footnotetext{
41 “'YOU'RE OUT!' the umpire screamed. Then I knew that I was not accepted. David and I were not accepted. The others wanted me 'out' because I was supposed to be 'out'."

42 "They knew David and I were friends. It was because of David that I wasn't wanted."

43 "All a guy needed was a chance. Somebody was always controlling who got a chance and who didn't."
} 
interrompe a prática de educação física por causa de sua acne, impedindo-o de vez de jogar futebol americano por todo o ensino médio. Essa autoexclusão do futebol faz com que seja tido como covarde pelos seus colegas (BUKOWSKI, 1982). Mais do que nunca, Henry Junior está displaçado, excluído simbolicamente da nação por não poder tomar parte de um esporte emblema da 'americanidade'.

Mais tarde, quando o futebol americano aparece pela última vez na narrativa, Henry Junior já está na universidade, com uma noção de pertencimento mais desenvolvida; e sua vontade de fazer do grupo já não existe. Ele entra numa partida somente para enfrentar o 'valentão' do jogo e extravasar uma agressividade contida, o que o faz. Ao fim da agressão, o resto do time o convida a continuar jogando, quando ele responde: “"Foda-se' [...] 'Eu odeio esportes'."44 (BUKOWSKI, 1982, p. 306). Privado de jogar e de pertencer a grupos esportivos ao longo de sua juventude, Henry Junior opta por não querer mais participar dos esportes nacionais, e simbólica e metonimicamente, da própria nação. Não obstante, Henry Junior será execrado não somente pela sua origem e por esportes.

\subsection{Contra o sonho americano}

Para iniciar essa seção, que trata de um tema mítico nos EUA, recorro à Ham on Rye. Já sabemos que os EUA atraíram e atraem imigrantes em busca de oportunidades e melhoria de vida. Tal busca por parte dos alemães é revelada pelo narrador em visita ao avô Leonard: "Ele fora um oficial do exército na Alemanha e viera para a América quando ouviu que as ruas eram asfaltadas com ouro. Elas não eram, então ele se tornou chefe de uma empresa de construção.”45 (BUKOWSKI, 1982, p. 3). Portanto, desde a infância, Henry Junior começa a se conscientizar do papel que a busca de dinheiro tem na vida de sua família e da sociedade de seu 'país-hospedeiro'. As 'ruas de ouro' obviamente não existem, mas constituem uma metáfora emblemática do que é o 'sonho americano'. O avô de Henry Junior com a família representam os imigrantes que vão para os EUA, além dos próprios estadunidenses, em busca do sonho.

\footnotetext{
44 "“Fuck it, [...] I hate sports."”

45 "He had been an army officer in Germany and had come to America when he heard that the streets were paved with gold. They weren't, so he became the head of a construction firm."
} 
Tal termo, talvez não coincidentemente, é enfatizado no período entre guerras. Ele tem sua definição constantemente revisitada por acadêmicos. Um deles, Lawrence R. Samuel (2012), em The American Dream: a Cultural History, afirma que o 'sonho americano' nasce antes da nação, e que é uma vitória da meritocracia do Novo Mundo sobre a aristocracia do Velho. Segundo Edward Pessen (1988, p. 270), a "maioria dos americanos parece convencida de que o Novo Mundo é [...] mais inocente e igualitário que o Velho [...]”46. Entretanto, em Ham on Rye, essa visão inocente de ausência de status social não é compartilhada e sentida por Henry Junior. Em uma sociedade, como a dos EUA, na qual o sucesso financeiro é altamente valorizado, os indivíduos que não o possuem estão fadados a viver às margens. Consequentemente, esses sujeitos estão predestinados a não realizar o ‘sonho americano'.

O crítico Russel Harrison (1994) que avalia a questão da classe social nas obras de Charles Bukowski, lembra-nos que o 'sonho americano' foi definido classicamente por Benjamin Franklin em sua autobiografia. Possuir um pedaço de terra, anseio de mobilidade social, independência e estabilidade financeira, alcançar uma agradável aposentadoria e autorrealização são aspectos que compõem a definição clássica e otimista do 'sonho'. Nota-se que esse termo mítico carrega alto teor materialista, que molda a cultura estadunidense e a formação do Estado-nação, tanto positiva quanto negativamente.

Desde o fim do século XIX até os meados do século passado, os EUA vêm se afirmando como potência capitalista mundial. Numa era pós-Belle Époque, os EUA são protagonistas planetários capazes de ajudar na reconstrução da Europa no pós-I Grande Guerra e de fazer frente aos comunistas no pós-Revolução Russa (1917). Junto a isso, somase o desenvolvimento técnico estabelecido na Segunda Revolução Industrial (1850-1939), claramente demonstrado pela expansão da eletricidade e da comunicação nos centros urbanos, e também pela ampliação da indústria automotiva e da de aviões (TINDALL, 1984). Além disso, nessa época, os EUA estão passando por uma intensa transformação sociocultural. Devido à opulência e a crescente urbanização, os chamados The Roaring Twenties e a Jazz. Age mudam a forma do estadunidense encarar tabus e produzem uma onda de inovações, influenciando a música, a literatura e o cinema.

Em Ham on Rye é possível perceber como uma época próspera num país novo influencia o imaginário infantil. O Ford Modelo T, o primeiro automóvel a ter produção em massa na história, considerado um dos símbolos do 'fordismo' e da indústria norte-americana, é mencionado onze vezes por Henry Junior nos quatro primeiro capítulos da narrativa

\footnotetext{
46 "most Americans seem convinced that the New World is $[. .$.$] more innocent and egalitarian than the Old."$
} 
(BUKOWSKI, 1982), momento em que a personagem é apenas um pequeno garoto imigrante recém-chegado aos EUA. Dentro de um então revolucionário e acessível modelo T, a classe média estadunidense pode pela primeira vez viajar facilmente, privilégio para poucos antes. Essa mudança é evidenciada pelo narrador quando a avó alemã os visita: "Ela nos visitava frequentemente depois que viemos para a América, pegando o bonde vermelho de Pasadena para Los Angeles. Nós só a visitávamos de vez em quando, dirigindo o Ford Modelo T."47 (BUKOWSKI, 1982, p. 2). A produção em massa é o advento que permite incrementar o acesso ao consumo. A posse de bens materiais, especialmente o automóvel, e os supostos benefícios desta posse tornam-se um ícone do imaginário de 'ser americano', promovendo a vontade de acumulação.

Henry Junior detecta, em seu pai, características de pessoas ambiciosas que querem realizar o 'sonho americano'. Isto aparece na obsessão em ser rico e bem-sucedido, mesmo que isso signifique mentir para si mesmo, roubar ou fingir para os outros. Um exemplo dessa percepção é na ocasião em que a personagem, ainda muito criança, encontra-se sem amigos porque os pais o proíbem de se misturar com os outros: “"Elas são crianças más,' disse meu pai, 'os pais delas são pobres.' 'Sim' concordou minha mãe. Meus pais queriam ser ricos então eles se imaginavam ricos."48 (BUKOWSKI, 1982, p. 21). O pai, um entregador de leite morando num bairro de classe-média baixa, projeta-se superior aos seus pares, mesmo não o sendo, e a mãe passiva, aceita.

Harrison (1994) faz uma leitura histórica interessante do início do romance, no trecho em que o pai de Henry Junior rouba laranjas dos laranjais californianos (BUKOWSKI, 1982): os laranjais representam uma aristocracia rural-urbana da Califórnia no começo do século passado. O pai de Henry Junior, rancoroso por não ser rico, rouba laranjas como forma de redistribuir a renda (HARRISON, 1994) para si mesmo. Quando confrontado pelo dono da fazenda, o pai de Henry tenta se justificar: "Estou pegando laranjas. Há muitas laranjas. [...] Você não sentirá falta de algumas malditas laranjas. [...] Você não precisa de tantas laranjas"49 (BUKOWSKI, 1982, p. 7), para logo depois sentenciar: "Caras como você deveriam ser enforcados!" 50 (BUKOWSKI, 1982, p. 7). Tentando convencer a si mesmo, o

\footnotetext{
47 "She visited us often after we came to America, taking the red trolley in from Pasadena to Los Angeles. We only went to see her occasionally, driving out in the Model-T Ford."

48 “'They are bad children,' said my father, 'their parents are poor.' 'Yes,' agreed my mother. My parents wanted to be rich so they imagined themselves rich."

49 “"I'm picking oranges. There are plenty of oranges. [...] You're not going to miss a few god-damned oranges. $[\ldots]$ You don't need all these oranges."

50 "'Guys like you ought to be hung!"”
} 
pai do protagonista, vítima da imobilidade social provocada pelo 'sonho americano', tenta fazer justiça com as próprias mãos e alcançar de qualquer maneira o 'sonho'.

Voltando ao contexto histórico explorado pela narrativa, embora o princípio do século XX seja de grande prosperidade para os EUA, ao fim da década de 1920, dá-se uma das maiores crises capitalistas da história, afetando diretamente o mercado de trabalho, as finanças públicas e o poder de compra do cidadão estadunidense. Consequentemente, a realização do 'sonho' fica comprometida: o pai de Henry Junior, juntamente com os pais dos colegas da escola, perde o emprego.

Mesmo desempregado após a crise de 1929, o pai de Henry Junior não para de perseguir o 'sonho' de forma ilusória, fantasiando ser superior aos demais: "Minha mãe ia para o seu emprego de baixa remuneração toda manhã e meu pai, que não tinha emprego, saía toda manhã também. Apesar de a maioria dos vizinhos serem desempregados, ele não queria que pensassem que ele não tinha emprego."51 (BUKOWSKI, 1982, p. 120). Harrison (1994) afirma que esta faz parte de uma demonstração de não aceitação por parte do pai de Henry Junior de ser integrante da classe de trabalhadores. Apesar de sempre qualificar Leonard e seus irmãos como perdedores, o pai do protagonista não possui nada a mais que eles, colocando-o no mesmo patamar dos familiares pobres e, conforme citado, dos vizinhos também desempregados. O pai de Henry Junior não somente perde o seu emprego de baixa qualificação, como também se autopromove em sua imaginação: “'Sou um engenheiro,' ele dizia às pessoas. Ele sempre quisera ser um engenheiro."52 (BUKOWSKI, 1982, p. 138). Essa entrega à sua persona inventada faz com que o pai do protagonista se torne um escravo da ambição de ser rico.

Para auxiliar as vítimas da depressão, como é o caso da família Chinaski em Ham on Rye, e também como forma de ajudar na reconstrução do país, o governo do então presidente Franklin D. Roosevelt (1933-1945) cria diversos planos de assistência, sendo um deles distribuição gratuita de comida (TINDALL, 1984). Na narrativa, os pais de Henry Junior, para não serem vistos como necessitados de tal subsídio, buscam seus mantimentos num bairro afastado de onde moram para que os vizinhos não os vejam:

Então eles andavam duas milhas pela Washington Boulevard, até uma loja alguns quarteirões depois de Crenshaw. Era uma longa caminhada. Eles caminhavam as duas milhas de volta, suando, carregando as sacolas de compra cheias de latas de hash, batatas, mortadela e cenouras. Meu pai não

\footnotetext{
51 "My mother went to her low-paying job each morning and my father, who didn't have a job, left each morning too. Although most of the neighbors were unemployed he didn't want them to think he was jobless."

52 "'I'm an engineer,' he told people. He had always wanted to be an engineer."
} 
dirigia porque ele queria economizar gasolina. Ele precisava da gasolina para dirigir para o seu emprego invisível. ${ }^{53}$ (BUKOWSKI, 1982, p. 149)

Esse constante devaneio envolvendo 'ser e ter' do pai, afeta diretamente a educação formal de Henry Junior. Ao terminar o ensino fundamental, ele precisa ir para o ensino médio. Há uma escola perto de casa, contudo, seu pai persiste em colocá-lo numa escola que fica muito mais longe: “"Você vai fazer o que eu mandar. Vai se matricular na Chelsey High.' Eu sabia porque ele me queria na Chelsey. Os garotos ricos estavam lá. Meu pai estava louco. Ele ainda pensava em ser rico." ${ }^{54}$ (BUKOWSKI, 1982, p. 135).

Sendo pobre num colégio de ricos, o conflito de classes e o displaçamento social são mais exacerbados, especialmente no contexto da Grande Depressão. No primeiro dia de aula, Henry Junior e seu amigo Baldy chegam à escola de bicicleta e se sentem totalmente deslocados: "Era uma sensação terrível. A maioria daqueles garotos, pelo menos os mais

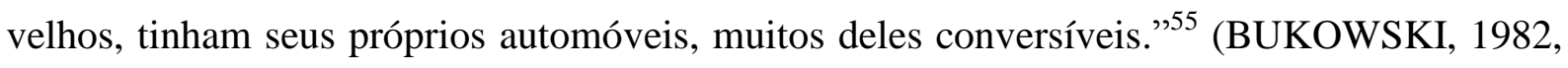
p. 135). Alijado da possibilidade de possuir um automóvel, a personagem começa a sentir que o ‘sonho americano’ não é para todos. Mesmo a aparência dos garotos ricos é diferente:

Todos estavam bem vestidos, os meninos e as meninas, eles tinham suéteres, relógios de pulso e sapatos da moda, eles pareciam bem adultos, serenos e superiores. E lá eu estava com minha camisa feita em casa, calças esfarrapadas, meus sapatos arruinados [...]. ${ }^{56}$ (BUKOWSKI, 1982, p. 136)

A sensação de inferioridade perante os estudantes ricos durante a vida escolar de Henry Junior e a falsidade de seus pais para parecerem ricos presenciada em casa gera uma reação a qual Harrison (1994) chama de "autoridade incomum" na personagem. O consumo e acumulação, pilares da sociedade estadunidense e suportada ideologicamente pela busca do 'sonho americano', começam a não fazer parte do projeto de vida de Henry Junior (HARRISON, 1994). Tal rejeição ao elemento materialista do sonho americano funciona como uma forma da personagem buscar sua própria individualidade. De certa forma, Henry Junior passa a desconstruir o 'sonho americano', fazendo uma oposição a seus pares

\footnotetext{
53 "So they walked two miles down Washington Boulevard, to a store a couple of blocks past Crenshaw. It was a long walk. They walked the two miles back, sweating, carrying their shopping bags full of canned hash and potatoes and bologna and carrots. My father didn't drive because he wanted to save gas. He needed the gas to drive to and from his invisible job."

54 “'You'll do as I tell you. You'll register at Chelsey High.' I knew why he wanted me to go to Chelsey. The rich kids went there. My father was crazy. He still thought about being rich."

55 "It was a terrible feeling. Most of those kids, at least all the older ones, had their own automobiles, many of them new convertibles."

56 "Everybody was nicely dressed, the guys and the girls, they had pullover sweaters, wrist watches and the latest in shoes, They seemed very adult and poised and superior. And there I was in my homemade shirt, my one ragged pair of pants, my rundown shoes [...]"
} 
consumistas, que o desprezam ao longo da narrativa, e a seu pai, um sujeito obcecado e frustrado por ter sido enganado pela busca do 'sonho'.

No entanto, o estabelecimento desta individualidade não está isento de conflitos. Ao questionar-se o quão amaldiçoado é por ter nascido na sua família e quão enfadonha a lógica da acumulação de capital ensinada por seu pai é, ele entende a mobilidade social estadunidense como ilusória: “[...] aprendi que os pobres normalmente continuam pobres [...] não havia nenhum talvez. Riqueza significava vitória e vitória era a única realidade., 57 (BUKOWSKI, 1982, p. 214). Ainda que entenda a lógica capitalista e rejeite o 'sonho americano' de buscar fortuna, tornando-se assim um pouco mais livre, Henry Junior compreende que seu percurso não será fácil numa sociedade tão cruel que estabelece sucesso e vitória de acordo com posses.

Mesmo o primeiro emprego não o instiga. Depois de anos ouvindo o pai discutindo "o emprego" na mesa de jantar, quando chega a hora de celebrar o seu primeiro trabalho, Henry Junior não demonstra nenhum contentamento. O pai sempre dorme cedo para chegar ao trabalho renovado. Henry Junior pondera: "Mas isso não fizera muito bem pra ele. Eu decidi que talvez eu devesse reverter o processo" "58 (BUKOWSKI, 1982, p. 232) e sabe que aquela vida monetariamente fetichista que seu pai prega não funciona para ele:

\begin{abstract}
Agora, eu pensei, empurrando meu carrinho, eu tenho esse emprego. Vai ser isso, então? Não surpreendia que homens roubassem bancos. Havia muitos trabalhos degradantes. Por que diabos eu não era um juiz da corte superior ou um pianista concertista? Porque era necessário treinamento e treinamento custava dinheiro. Mas eu não queria ser nada de qualquer forma. E eu estava certamente tendo sucesso. ${ }^{59}$ (BUKOWSKI, 1982, p. 233)
\end{abstract}

Ironicamente, Henry Junior se considera um sucesso em ser um perdedor, contrastando a concepção aceita de sucesso ligada à quantidade de bens materiais. Dentro da loja onde trabalha, ao ser confrontado e intimidado por ex-colegas ricos do colégio pelo fato de ele ter sempre uma atitude superior e ao mesmo tempo por ser covarde por não ter participado do time de futebol americano, ele pensa consigo: "Eles eram lindos nadas. Eles me davam nojo. Eu os odiava. Eles eram parte do pesadelo que sempre me assombrou de uma

\footnotetext{
57 “[...] I learned that the poor usually stay poor [...] there weren't any maybes. Wealth meant victory and victory was the only reality."

58 "I decided that I might try to reverse the process."

59 "Now, I thought, pushing my cart along, I have this job. Is this to be it? No wonder men robbed banks. There were too many demeaning jobs. Why the hell wasn't I a superior court judge or a concert pianist? Because it took training and training cost money. But I didn't want to be anything anyhow. And I was certainly succeeding."
} 
forma ou de outra." ${ }^{60}$ (BUKOWSKI, 1982, p. 236). Percebe-se que os garotos ricos, portanto bem sucedidos, são classificados como pesadelo para Henry Junior, contestando a noção de sonho.

Ao contrapor a busca do 'sonho americano' com as consequências de tal busca, a personagem expõe ao longo da narrativa as contradições de uma sociedade composta por indivíduos medíocres, ora pobres, como seu pai, ou mesmo ricos, como os colegas de escola, desmistificando e desconstruindo o 'sonho americano'. Finalmente, para Henry Junior, o ‘sonho' almejado pelo estadunidense médio é um sonho falso a não ser seguido, a ser evitado para que não o transforme em uma pessoa comum e mesquinha.

\subsection{O lar}

Discuti até agora como a nação e respectivas articulações influenciam a formação da identidade nacional e cultural da personagem Henry Junior. Cabe agora debater outro fator que possui profunda significância no desenvolvimento da personalidade e da identidade de um indivíduo: o lar. Este termo apresenta-se como semanticamente problemático, principalmente se considerarmos o equivalente inglês home, o qual possui diferentes significados: morada ou terra natal (homeland ou home-country) de um indivíduo. Contudo, mesmo sendo de difícil definição, ao analisarmos Ham on Rye, a variedade de possibilidades de uso da palavra lar é revertida ao nosso favor. Devido à grande importância dada por Bukowski a esse tema na obra, são possíveis diferentes abordagens para se explicar o displaçamento social da personagem representada pelo escritor no que concerne lar e a interação desta com outras esferas.

Preliminarmente, acredito que o filósofo francês Gaston Bachelard em A poética do espaço ([1957] 1978) pode nos dar um belo exemplo de como o lar é, ou era, entendido por parte dos acadêmicos. Com sua abordagem fenomenológica, o lar é para Bachelar ([1957] 1978, p. 200-201) o "nosso primeiro universo [...] o primeiro mundo do homem [...] a vida começa bem; começa fechada, protegida, agasalhada no seio da casa.” A casa como lar pode estar em relação metonímica com o indivíduo, é um abrigo que o protege contra o externo. Portanto, é nítido que Charles Bukowski contesta essa concepção.

\footnotetext{
60 "They were beautiful nothings. They made me sick. I hated them. They were part of the nightmare that always haunted me in one form or another."
} 
Ulteriormente, a professora Sara Ahmed (2000, p. 77) argumenta: “[L]ar é aqui, não um lugar particular que alguém simplesmente habita, porém mais que um lugar."61 Levandose em conta lar como uma noção de terra natal, o protagonista de Ham on Rye não o tem, está longe dele e não possui vínculos concretos com o mesmo. De acordo com a teoria de Ahmed, posso considerar que Henry Junior é um "hóspede, que depende da hospitalidade dos outros" 62 (AHMED, 2000, p. 77), porém quase nunca a encontra. "[A] escrita da história da nação, na qual o sujeito se permite encaixar"63 (AHMED, 2000, p. 77) é uma forma de memória coletiva na qual Henry Junior não está inserido. Conforme visto, a personagem possui, em certo ponto da narrativa, uma vontade de pertencer à nação. No entanto, a rejeição sofrida faz com que homeland se torne um fetiche para ela.

O lar é um fetiche para quem não o tem, é algum lugar a que se está indo e nunca chegando. O lar, portanto, é um destino, um futuro (AHMED, 2000). No contexto em que vivemos num sistema de Estados-nação, há o que Ahmed chama de "relação entre identidade, pertencimento e lar" ${ }^{\prime 64}$ (AHMED, 2000, p. 78) e não é diferente em Ham on Rye. A condição de estranhamento de Henry Junior, considerando a argumentação de Ahmed (2000, p. 78), é "determinada pelo evento de deixar o lar [...]"65. Deste modo, a personagem é um sujeito que não faz parte da memória coletiva de construção de nação, vagando em direção a um desconhecido destino e que não pertence ao 'grande lar' Estados Unidos da América. Esse deslocamento migratório produz um sentimento de perda e de displaçamento social na personagem.

A origem e a condição social, por conseguinte, pesam na representação da personagem. Henry Junior é um sujeito socialmente displaçado e considerado "estranho" pelos estadunidenses 'originais', levando-o derradeiramente a negar os valores impostos pelo país-hospedeiro e a isolar-se dos cidadãos dos EUA. Uma possível saída ou alívio para essa condição de estranhamento seria se refugiar no próprio lar, considerando a própria morada como ambiente familiar confortável, o que é uma tendência de povos diaspóricos, exilados, ou mesmo famílias de imigrantes: unirem-se para se proteger (CLIFFORD, 1997) das intempéries do país-hospedeiro. Possibilidade que Henry Junior não encontra.

Para explicar como essa impossibilidade é articulada na narrativa é necessário um aprofundamento teórico sobre o tema. Rosemary Marangoly George é outra estudiosa

\footnotetext{
61 "home is here, not a particular place that one simply inhabits, but more than one place."

62 "guest, relying on the hospitability of others."

63 "[T] "

64 "relationship between identity, belonging and home."

65 "determined by the event of leaving home."
} 
interessada em lar. Em Politics of Home (1996), a autora argumenta que lar pertence à esfera privada, mas também representa, em termos mais amplos, um "maior espaço geográfico a onde alguém pertence: país, cidade, vilarejo, comunidade."66 (GEORGE, 1996, p. 11). Enquanto isso, o país, ou mesmo a comunidade seria relativo à esfera pública. George problematiza a questão do lar inquirindo quando o privado influencia o público e vice-versa (GEORGE, 1996). Assim como religião, nação, raça ou classe são comunidades imaginadas, o mesmo se pode dizer de lar. George (1996, p. 11) afirma que a "ficcionalização é um atributo intrínseco do lar" ${ }^{\circ 7}$, levando-nos novamente à política dos jogos de poder e expandindo as possibilidades de aplicação de do termo.

Ao estudar tal tema, George (1996) se utiliza do trabalho de Edward Said para diferenciar dois tipos de afinidade cultural que um sujeito possui com lugares e pessoas. Temos "filiação" como sendo a ligação biológica, geográfica e cultural natal; e "afiliação" como ligação forjada a outras criações sociais, tais como instituições e associações (GEORGE, 1996). Há um movimento de filiação em direção à afiliação ao longo da vida de um indivíduo, denotando uma circulação entre natureza e cultura.

O que é interessante na proposta de definir lar para minha dissertação é a crítica que George (1996) faz ao afirmar que tanto filiação quanto afiliação são criadas e aprendidas, e assim sendo, nenhuma poderia ser considerada natural. Henry Junior, nos primeiros sete capítulos da narrativa, é uma criança tentando entender o mundo ao seu redor. Quando ele recebe injustamente uma advertência escolar por culpa de colegas que o maltratam, seu pai o surra violentamente sem justificativa pela primeira vez: "Essa seria a primeira de muitas surras, que ocorreriam mais e mais frequentemente. Sempre, eu sentia, sem motivo real." (BUKOWSKI, 1982, p. 34). A partir de então, Henry Junior nunca mais usa a palavra "lar" em sua narração, sua residência passa a ser "a casa do meu pai”, "casa dele”, "casa dos meus pais", "lugar onde eu vivia" ou "a casa" (BUKOWSKI, 1982), evidenciando uma ruptura com sua filiação familiar.

Logo após a primeira sova, Henry Junior pondera: "Eu senti que até o sol pertencia ao meu pai, que eu não tinha direito a ele porque estava brilhando sobre a casa de meu pai. Eu era como suas rosas, algo que pertencia a ele e não a mim." ${ }^{\text {"69 }}$ (BUKOWSKI, 1982, p. 35). A

\footnotetext{
66 "larger geographic place where one belongs: country, city, village, community."

67 "fictionality is an intrinsic attribute of home."

68 "It was going to be the first of many such beatings, which would recur more and more often. Always, I felt, without real reason."

69 "I felt that even the sun belonged to my father, that I had no right to it because it was shining upon my father's house. I was like his roses, something that belonged to him and not to me."
} 
personagem usa a expressão 'pertencer' com sentido de posse, como se fosse um objeto, não como significado de filiação à família. A suposta ligação mais natural que um sujeito pode ter, a família, está rompida: a personagem percebe que tal ligação é forjada, assim como George (1996) sugere. O sentimento de não pertencimento começa a influenciar a formação de identidade da personagem ainda criança e dentro do próprio lar.

Se o pai do protagonista é o menos afetuoso possível, Katherine, a mãe, é um símbolo de aceitação e submissão. Ao ser questionada por Henry Junior por que permite que o pai o agrida sem motivo, ela simplesmente responde: "O pai está sempre certo."70 (BUKOWSKI, 1982, p. 35). Mães, segundo a abordagem feminista de George (1996), são representações do pensamento machista de uma época, retratadas por meio de sujeitos incapacitados e fracos, pelo fato do feminino estar tradicionalmente e pejorativamente vinculado ao lar. Da filiação familiar, Henry Junior encontra submissão e conformismo por parte da mãe; e injustiça, machismo e brutalidade por parte do pai. À noite, horas depois da surra, Henry Junior faz uma avaliação de sua condição deslocada: “[E]ssas pessoas não são meus pais, eles devem ter me adotado e agora estão infelizes com o que me tornei." ${ }^{, 71}$ (BUKOWSKI, 1982, p. 37). Tal sentimento de desfiliação natural se junta ao sentimento de desfiliação cultural referente à comunidade imaginada dos EUA, complementando-se em um displaçamento social.

Assim como indica George (1996), ao controlar o espaço físico, controla-se o indivíduo. Lar é tanto um local de inclusão quanto de exclusão: “[...] 'lar' se torna um fundamento contestado em tempos de tumulto político tanto no nível [...] nacional [...] quanto no nível interpessoal familiar." ${ }^{, 2}$ (GEORGE, 1996, p. 18). As esferas públicas e privadas não são inorgânicas com respectivos desenvolvimentos separados uns dos outros. George (1996) diz que o público invade o privado e pode-se dizer que movimento inverso também ocorre.

O pai de Henry Junior é um patriarca sexista e mesquinho em busca do 'sonho americano', e apesar da descendência e da família alemãs, afilia-se à nação por meio da língua e de seus valores materialistas. É de se esperar que um indivíduo como esse não se oponha à assimilação cultural por parte de seu filho. Contudo, como já citado, ele não deixa Henry Junior brincar com as crianças do bairro por se imaginar melhor que os outros, alimentando certo paradoxo. Ora, ao se inserir na cultura estadunidense, por que não deixar o próprio filho

\footnotetext{
70 “"The father,' she said, 'is always right."”

71 "these people are not my parents, they must have adopted me and now they are unhappy with what I have become."

72 “"home' becomes contested ground in times of political tumult either on the level of [...] national [...] or the interpersonal familiar level."
} 
participar de esportes-símbolo do país onde vivem? Isso não seria uma forma de se afiliar mais profundamente à comunidade, facilitando a realização do 'sonho americano'?

Porém, o que pode ser visto é justamente o contrário. Henry Junior, em uma das únicas chances de jogar futebol americano na rua, é interrompido pelo pai para a limpeza do jardim (BUKOWSKI, 1982), impossibilitando a personagem de se inserir no grupo. Outro exemplo desse tipo de atitude é quando Henry Junior tem a tarefa de tomar notas do discurso do presidente Herbert Hoover (1929-1933) em Los Angeles para uma tarefa da escola. Além de assistir um discurso presidencial ser uma atitude estadunidense, interessantemente, Herbert Hoover é o primeiro presidente de descendência alemã a governar o país ${ }^{73}$ na história, algo que poderia ser fator de afiliação por parte do pai de Henry Junior. Mas o pai não o deixa ir, pois é sábado, dia de cortar a grama. A autoridade massacrante do pai deve ser exercida a qualquer custo, denotando que o privado é convenientemente mais importante que o público.

Outro claro exemplo da inter-relação público-privado influenciando a identidade da personagem está na passagem a seguir:

Mas eu continuei a ter problemas com os outros garotos na vizinhança. Meu pai não ajudava. Por exemplo, ele me comprou uma vestimenta de índio e arco e flecha enquanto todos os outros garotos tinham fantasia de cowboy. Era o mesmo que na escola - eles se juntavam contra mim. Eles me cercavam com suas roupas de cowboy e suas pistolas, mas quando a situação apertava eu colocava uma flecha no arco, puxava para trás e esperava. Isso sempre os afastava. Eu nunca vestia minha roupa de índio a não ser que me pai me fizesse vesti-la. ${ }^{74}$ (BUKOWSKI, 1982, p. 89)

Nos EUA, tanto na história oficial quanto na ficção, os índios são os inimigos selvagens a serem combatidos pelos bravos e aventureiros colonizadores brancos. Henry Junior, além de ser proibido de participar de atividades com outras crianças, quando finalmente o faz, é forçado pelo próprio pai a vestir a 'roupa do inimigo'. Isso não somente exacerba a condição displaçada do protagonista na narrativa, como também nos serve de importante símbolo para desvendar como Henry Junior se sente em casa e é visto pelo pai: um inimigo.

Faz-se necessário citar mais duas passagens. Henry Junior está sofrendo de um caso raro de acne e o pai exclama: "Por que eu tive que ter um filho assim?"75 (BUKOWSKI,

\footnotetext{
${ }^{73}$ Disponível em: <http://usa.usembassy.de/>. Acesso em: 03 de Julho de 2015.

74 "But I continued to have trouble with the other kids in the neighborhood. My father didn't help. For example, he bought me an Indian suit and a bow and arrow when all the other kids had cowboy outfits. It was the same then as in the schoolyard - I was ganged-up on. They'd circle me with their cowboy outfits and their guns, but when it got bad I'd just put an arrow into the bow, pull it back and wait. That always moved them off. I never wore that Indian suit unless my father made me put it on."

75 "Why did I have to have a son like this?"
} 
1982, p. 137). Mais adiante, os pais de Henry Junior estão a compará-lo a outro garoto mais estudioso, quando o pai profere: “Às vezes eu não posso acreditar que ele é meu filho.,"76 (BUKOWSKI, 1982, p. 197). Percebe-se que constantemente Henry Junior vive sendo literalmente desfiliado de seu meio natural. A derradeira desfiliação familiar ocorre quando o pai descobre que Henry Junior escreve contos. Isso é inconcebível para aquele, o que resulta na expulsão do protagonista de casa. Henry Junior está empiricamente desfiliado.

A esfera privada sobrepõe a pública para o pai da personagem. Viver nos EUA, a terra de oportunidades e de possibilidade de riqueza, é interessante. Todavia, o pluralismo cultural e interação social propostos pela comunidade são rejeitados desde o início da narrativa. Não há a afiliação completa, e isso não ocorre por percepção do todo, mas sim por causa de medo, rancor, ignorância e preconceito por parte do pai. Já para Henry Junior, isso se circunstancia em mais uma forma de recusar laços, pelo fato de os mesmos serem imaginários; enquanto que a ligação forjada da natureza foi descoberta por meio de abandono e sofrimento dentro do próprio lar. Já no fim do romance, Henry Junior sai da casa dos pais e está pronto para descobrir a vida sem as amarras da filiação forçada.

Minha interpretação é que Charles Bukwoski problematiza a noção de lar com a sua personagem Henry Junior. Os valores de proteção, abrigo e filiação que o lar deve proporcionar, Henry Junior não os sente. O benefício mais precioso da casa para Bachelard ([1957] 1978) é a permissão de sonhar em paz, é o abrigo do devaneio. Já para o protagonista de Ham on Rye, é justamente o contrário. Fora do lar, um sujeito experimentaria pela primeira vez a hostilidade dos homens, já Henry Junior tem contato com ela dentro da própria casa. $\mathrm{O}$ universo de Henry Junior passa a ser construído por ele mesmo. Ora se tranca no seu quarto, ora devaneia com uma caverna. O mundo externo, a sociedade, que também pode ser chamado de lar, também não o aceita. Henry Junior é então um sujeito displaçado socialmente: desafiliado da nação e desfiliado do próprio lar. Todavia, por finalmente perceber forçosamente que ambas as ligações são inventadas, ele está mais preparado para enfrentar a "hostilidade do universo". Ele não se sente necessariamente mal, mas perdido, porém livre.

\footnotetext{
76 "Sometimes I can’t believe he's my son."
} 


\subsection{Identidade diaspórica e mobilidade como elementos do displaçamento social em Ham on Rye}

Para concluir esta primeira parte do trabalho sobre displaçamento social e para estabelecer uma ponte para a próxima seção, que também trata de displaçamento, emprego conceitos de identidade diaspórica e de mobilidade. Estes elementos se encontram representados por intermédio da protagonista Henry Junior e trazem uma possibilidade de se analisar as identificações culturais de um indivíduo em relação à sociedade.

Diáspora, tradicionalmente, é um termo de origem grega e que se refere a uma violenta dispersão coletiva com desejo de retorno à terra natal, tendo como exemplo ideal os judeus expulsos da Palestina. Contudo, tal noção tem sido expandida, ampliada e revisada pela comunidade acadêmica, sendo extensamente empregada nas últimas décadas, em estudos sociais e literários, adquirindo significados mais abstratos e se relacionando a diversos povos, e tendo às vezes, alguns teóricos utilizando o termo com foco em indivíduos. Apesar dos questionamentos sobre definição, com teóricos a favor e outros contra a expansão do uso do vocábulo, alguns aspectos teóricos da diáspora são úteis para analisar Henry Junior.

James Clifford (1997) parece ter encontrado uma forma perspicaz de abordar a diáspora voltada para os tempos modernos. Como forma de evitar conflitos com tradicionalistas, ele frequentemente trabalha com "elementos diaspóricos" em seu livro Routes (1997). Em Ham on Rye, parece-nos óbvio que Henry Junior não se encontra em diáspora segundo o seu significado clássico, porém pode-se dizer que, na construção de identidade da personagem, há a presença de “dimensões diaspóricas". Henry Junior não está exilado geograficamente, mas sim social e culturalmente. Ele não possui uma intenção derradeira de retorno à Alemanha, mas sente-se discriminado e excluído na nação em que vive, assim como sujeitos diaspóricos muitas vezes se sentem ao longo da história humana.

No romance, há contato entre culturas e nações, alemã e estadunidense, o que configura uma característica diaspórica. Outros aspectos diaspóricos como resistência à assimilação e uma "contínua história de displaçamento, sofrimento, adaptação ou resistência",77 (CLIFFORD, 1997, p. 250) são claramente representados por meio da personagem. Portanto, se usarmos os conceitos de Clifford acima, conclui-se que a personagem apresenta dimensões diaspóricas em sua caracterização.

\footnotetext{
77 “ongoing history of displacement, suffering, adaptation or resistance".
} 
Outra teórica da Sociologia que estuda diáspora é Avtar Brah. Em Diaspora, Border and Transnational Identities (1996), ela sugere que nem todos os discursos de diáspora sustentam uma ideologia de retorno, corroborando novos usos de diáspora. Também, segundo ela, a identidade de uma comunidade diaspórica não é fixa, em vista disso tampouco seria a identidade de um indivíduo pertencente a ela (BRAH, 1996). Portanto, apesar de Henry Junior poder ser entendido como um sujeito diaspórico, ele não deseja ou sequer pensa em retornar à nação alemã, mas às vezes pondera que talvez a Alemanha seja melhor para ele, mesmo ele não a conhecendo. Todavia, a identidade fragmentada da personagem, moldada ao longo da narrativa, é resultado de uma condição diaspórica.

Até agora, parece-me óbvio que o escritor Charles Bukowski representa em sua narrativa, por meio da personagem Henry Junior, consequências do displaçamento social em um indivíduo. O protagonista não se sente pertencente a quaisquer comunidades imaginadas presente na sociedade estadunidense, produzindo o que o geógrafo Tim Cresswell (2006) chama de movimentos de transgressão, bem como fixidez de resistência.

Cresswell, autor de On the Move: Mobility in the Modern Western World (2006) faz um aprofundado estudo de mobilidade e respectivas implicações, interações e articulações nas sociedades e indivíduos. Apesar de afirmar que "transgressão envolve displaçamento",78 (CRESSWELL, 2006, p. ix), ele também pondera que há "resistências que envolvem não se mover, ficar imóvel, resistindo a fluxos e movimentos dominantes [...]"79 (CRESSWELL, 2006, p. ix). Mobilidade é, simplificando, um movimento socialmente produzido. O que no Feudalismo é visto como transgressão, coisa de vagabundos, hoje pode ser enxergado como ausência de impedimento. Portanto, vemo-nos diante de movimentos físico-empíricos e também metafóricos sendo articulados politicamente entre sociedades e os indivíduos pertencentes a ela.

Inicialmente, Henry Junior desloca-se geograficamente da Alemanha para os EUA, imigrando junto com os pais em busca de oportunidades de prosperidade, configurando uma realidade empírica. Os dois locais possuem carga de significação na narrativa: Alemanha é o então inimigo da nação estadunidense e local de nascimento da personagem, contudo ela não possui nenhuma ligação fraternal com a mesma, por ter se mudado quando muito criança; os EUA são o novo lar de Henry Junior, onde tenta se inserir e onde não é bem-vindo. Está constituído então um paradoxal jogo de poder.

\footnotetext{
78 "transgression involves displacement."

79 "resistances that involve not moving, staying put, resisting dominant flows and motions [...]"
} 
Apesar do empirismo de seu movimento migratório, uma vez nos EUA, ele é apenas uma criança indefesa à mercê dos pais e da nação, e inicialmente não há para onde ir ou o que fazer, ainda mais se considerarmos o contexto de depressão econômica da época. Como então resistir ao status quo sem a prerrogativa da mobilidade? Como escapar das amarras de uma família bruta não sendo autossuficiente? E como transgredir um fetichismo monetário posto e tão intensamente imposto na sociedade em que a personagem vive? Ora, se não há perspectiva de mobilidade como forma de resistir, só lhe resta a fixidez, pelo menos por hora. E dentro de sua fixidez, será produzida resistência. Henry decide não praticar nenhum esporte, não trabalhar, largar a escola e não ir à guerra. Todas essas atitudes de 'não-movimento' se configuram como resistência aos valores pregados pela família e pela nação.

Cresswell (2006), para melhor contrapor mobilidade e fixidez, trabalha com duas metafísicas que influenciam o pensamento e ação dos homens: Metafísica do Sedentarismo e a Metafísica do Nomadismo, ambas aplicáveis para se analisar Henry Junior. Seguindo o conceito de Metafísica do Sedentarismo, a personagem é um outsider que não interessa para a nação. Ao controlar a mobilidade de um indivíduo, a nação controla quem são os nativos e qual é a cultura 'natural' de uma terra. A nação estadunidense, ao territorializar identidades, desterritorializa a identidade (CRESSWELL, 2006) do sujeito que é considerado não pertencente a ela, como por exemplo, dos descendentes e imigrantes alemães no entre guerras. A mobilidade, nesta metafísica, implica ausência de compromisso, envolvimento e significância. Basicamente, o outsider é visto como uma ameaça.

Paralelamente, tem-se a Metafísica do Nomadismo, em que a mobilidade está ligada a liberdade, mudança e progresso (CRESSWELL, 2006). Enquanto raízes e território implicam permanência, mobilidade representa uma quebra do sedentarismo. As experiências migratórias se encaixam na Metafísica do Nomadismo e dela surge o termo "pensamento nômade". Henry Junior, pode-se dizer, é um sujeito com "pensamento nômade" com uma "vida nômade", considerando um conceito pós-moderno do termo. Cresswell, ao citar Steven Best, explica que "vida nômade é um experimento em criatividade e em tornar-se, e é antitradicional e anticonformista em caráter. O Nômade pós-moderno tenta se livrar de todas as raízes, vínculos e identidades, e portanto resiste ao Estado e todos os poderes normalizadores." ${ }^{\prime 80}$ (CRESSWELL, 2006, p. 50). Aplicando este conceito de "pensamento

\footnotetext{
80 "Nomad life is an experiment in creativity and becoming, and is anti-traditional and anti-conformist in character. The postmodern nomad attempts to free itself of all roots, bonds and identities, and thereby resist the state and all normalizing powers."
} 
nômade", pode-se chegar a uma conclusão sobre a representação social do protagonista de Ham on Rye.

$\mathrm{Na}$ discussão sobre nacionalismo, Henry Junior desenvolve uma identidade nacional fragmentada; e na discussão sobre lar, chego ao entendimento de que Henry está desfiliado da família ao fim do romance. Ao ponderar sob a ótica do "pensamento nômade", fragmentação e desfiliação não são fundamentalmente negativas. Stuart Hall argumenta que: "A identidade é formada na interação entre o eu e a sociedade" (HALL, 1999, p.11), e conclui: "A identidade, então, costura o sujeito à estrutura [...]" (HALL, 1999, p.12). Henry percebe-se, ainda criança, não ser um sujeito autossuficiente, mas ao tentar preencher o seu eu fragmentado com o externo, entra em conflito com uma sociedade que não o aceita. Dessa forma, a identidade da personagem apresenta-se contraditória e em constante deslocamento. Concomitantemente, a sociedade "está constantemente sendo descentrada ou deslocada por forças fora de si mesma" (HALL, 1999, p.17), forças tais que na realidade objetiva são exemplificadas pela Grande Depressão e pela guerra vindoura, e as mesmas, sendo devidamente representadas na narrativa, influenciam a sociedade estadunidense, mas que não possuem tanta preponderância para a personagem displaçada. Esse contínuo confronto entre eu, sociedade e família faz com que Henry se fortaleça para resistir à fixidez reacionária dos que o rejeitam, resultando, na conclusão de Cresswell (2006) de que "displaçamento para de ser uma ameaça para ser uma virtude" ${ }^{\nexists 1}$, tal virtude o isola, mas também o ajuda a se defender dos que o subjugam.

Isto posto, será preciso retomar o pensamento nômade, de resistência, em uma abordagem mais interna, ou psicanalítica, no próximo capítulo.

\footnotetext{
81 "Displacement ceases to be a threat and becomes a virtue."
} 


\section{CONTRA SI MESMO}

The life of the sane, average man was dull, worse than death.

(Henry Junior)

\subsection{Civilização, uma fonte de hostilidade}

Não seguindo uma cronologia, mas a necessidade de atrelar este capítulo com o anterior, começo com Sigmund Freud. O livro O mal-estar na civilização (FREUD, [1929] 1997), não coincidentemente escrito no período entre guerras do século passado, mostra o médico austríaco preocupado com a saúde psíquica da civilização ocidental, inclusive citando a sociedade dos EUA como exemplo de uma coletividade que se desenvolve economicamente e tecnologicamente, mas que concomitantemente, prejudica o indivíduo. Para Freud ([1929] 1997), as forças da natureza e a decadência do corpo são fontes de desgosto contra as quais os seres humanos não podem lutar. Nossa atenção então se volta a uma terceira luta vã: a relação com outros humanos, constituindo-se esta como principal razão de sofrimento para um sujeito que vive em uma sociedade contemporânea. $\mathrm{O}$ indivíduo que sente e percebe que a civilização é causa de desgraças tentará escapar dela de diferentes maneiras, às vezes se utilizando contraditoriamente de coisas provenientes dessa mesma civilização.

Henry Junior, quando está a empurrar seu carrinho em seu primeiro emprego, devaneia: "O que eu queria era uma caverna no Colorado com três anos de mantimentos e bebidas." 82 (BUKOWSKI, 1982, p. 234). A personagem quer se isolar da sociedade, mas levando consigo suprimentos produzidos por ela. Esta passagem é um dos muitos exemplos de Henry Junior em conflito dialético com a civilização e, por consequência, consigo mesmo: ora deseja fazer parte dela, ora quer escapar da mesma. Um pouco antes na narrativa, ainda no colégio, a personagem pondera: "Nunca haveria um meio para eu viver confortavelmente com pessoas." ${ }^{83}$ (BUKOWSKI, 1982, p. 182). Henry Junior estabelece constantemente o externo como fonte de tormento, representado por família, escola e nação. Os conflitos que tem com

\footnotetext{
82 "What I wanted was a cave in Colorado with three-years' worth of foodstuffs and drink."

83 "There would never be a way for me to live comfortably with people."
} 
elas, que por vezes o faz questionar se ele mesmo não é a causa deles, se configuram, sob a ótica da psicanálise, como a construção de identidade frente à autoridade e repressão social.

\subsection{Henry versus Henry}

Um tema caríssimo para a psicanálise é o relacionamento do indivíduo na sua infância com os pais e as consequências desta relação na saúde psíquica do sujeito. Tanto para freudianos, lacanianos ou junguianos, é na infância e no lar que se dão os principais traumas e a primeira fragmentação do 'eu'. Freud, em seu trabalho maior, A Interpretação dos sonhos ([1899] 1987), utiliza-se de duas obras literárias clássicas, Édipo Rei e Hamlet, para ilustrar e respaldar uma contundente teoria: o ser humano sente vontade de matar o próprio pai. É o famoso Complexo de Édipo freudiano. Em Ham on Rye quando Henry Junior é achincalhado pelo pai à mesa de jantar logo após ter perdido o emprego, questiona-se: "Quem não quer matar o pai?" ${ }^{\prime 4}$ (BUKOWSKI, 1982, p. 242), remetendo a outra inspiração para Freud: o escritor russo Fyodor Dostoiévski, que influenciou o médico austríaco a elaborar a teoria do parricídio juntamente com os clássicos acima citados.

Se para Carl Gustav Jung ([1954] 1988) o Complexo é apenas uma figura de linguagem reducionista que exprime um sintoma e não uma causa, por outro lado, para Terry Eagleton ([1983] 1996, p. 136), ele é mais do que consequência de uma preliminar disputa por afeição da mãe, é "o começo da moral, consciência, lei e todas as formas de autoridade social e religiosa" ${ }^{\sharp 5}$. Esse encontro inicial da criança com o poder castrador do pai marca o nascimento do superego, a parte moral e repressora da mente humana que assimila o externo. Ainda na infância, a pessoa começa a desenvolver uma identidade individual, representada na mente humana pelo ego, que a faz se encaixar, moldar-se e adaptar-se à sociedade (EAGLETON, [1983] 1996). O inconsciente primitivo da mente humana, chamado de id, desconhece a moral, as leis e age por puro instinto, entrando em conflito com o superego. Inicialmente, segundo Freud, o humano, quando bebê, é guiado pelo princípio de prazer (EAGLETON, [1983] 1996) em uma busca anárquica por satisfação. Em contato com a autoridade paterna, há a formação do ego, quando os desejos da criança são inibidos e esta se ajusta resignadamente ao princípio da realidade.

\footnotetext{
84 "Who doesn't want to kill the father?"

85 "the beginnings of morality, conscience, law and all forms of social and religious authority."
} 
Conforme Eagleton ([1983] 1996), essa passagem denota uma transição da família para a sociedade, ou de natureza para cultura. Com isso, voltamos ao que Rosemary Marangoly George (1996) afirma sobre o movimento da filiação em direção à afiliação. Portanto, a autoridade personificada pelo pai encontrada na infância, reaparece na vida adulta via leis impostas pela sociedade, novamente inibindo desejos do sujeito. Todavia, os desejos, tanto da infância quanto da vida adulta, não deixam de existir, eles são apenas reprimidos e esse represamento não é a prova de falhas. Para Freud ([1913] 2012, p. 25): “[A] inibição [...] produz uma necessidade de descarga", ou seja, o desejo reprimido, eventualmente volta, mesmo que inconscientemente.

A principal forma de se acessar o inconsciente é por meio dos sonhos, e de acordo com Freud, neles os desejos reprimidos podem ser realizados: "[S]onhos para Freud são essencialmente concretizações simbólicas de desejos inconscientes [...] que precisam ser decifrados." ${ }^{86}$ (EAGLETON, [1983] 1996, p. 136). O inconsciente comunica o que quer dizer por meio de imagens que devemos de alguma forma traduzi-las para a nossa linguagem 'consciente': “[O] sonho é uma imagem simbolizada [...]” (LACAN, 2005, p. 40). Já de acordo com Jung ([1954] 1988, p. 54), apesar de caótico, o sonho possui uma organização interna e "se acha ligado a todas as tendências da personalidade do modo mais íntimo possível" tendo como uma das funções retratar tais tendências. Em parte, o autor suíço discorda de Freud. Para Jung, o sonho não é realização de desejos, mas sim uma compensação: "eles contém aquelas imagens, aqueles sentimentos, aqueles pensamentos, cuja ausência produz na consciência um vazio que é preenchido pelo medo, em lugar de ser substituído pela compreensão.” (JUNG, [1954] 1988, p. 92). Ainda segundo Jung ([1954] 1988, p. 93): “[O] significado e o conteúdo dos sonhos estão sempre em relação íntima com o estado ocasional da consciência" e isso não é diferente com Henry Junior.

Já citei e analisei passagens que mostram a personagem se sentindo deslocada dentro e fora de casa. Quando leva surras, o protagonista se sente um mero objeto pertencente ao pai. Ele acha que atrai amigos fracos. Ele não tem dinheiro e nem chance com as mulheres. Uma horrível acne aparece em seu corpo. Henry Junior, desiludido com sua vida, resolve então desafiar Deus:

Tudo bem Deus, digamos que Você esteja realmente aí. Você me colocou nessa. Você quer me testar. E se eu testar Você? E se eu disser que Você não está aí? Você me deu um teste supremo com meus pais e essas espinhas. Eu

\footnotetext{
86 "[D]reams for Freud are essentially symbolic fulfillments of unconscious wishes $[\ldots]$ which need to be deciphered."
} 
acho que passei no Seu teste. Sou mais valente que Você. Se Você descer aqui agora, cuspirei na sua cara, caso Você tenha uma cara. E você caga? O padre nunca respondeu essa questão. Ele nos disse para nunca duvidar. Duvidar do que? Eu acho que Você tem pegado muito no meu pé então estou pedindo para Você descer aqui para que Te teste! ${ }^{87}$ (BUKOWSKI, 1982, p. 153)

Logo após intimar Deus, Henry Junior cai no sono. Ele então sonha com uma figura fantasmagórica que não compreende bem. Em seguida, Henry Junior abre uma caixinha que sua avó lhe dera com pequenos papéis com dizeres da Bíblia. Ele retira um com a seguinte sentença: "DEUS TE ABANDONOU." 88 (BUKOWSKI, 1982, p. 155). Tentando decifrar o único sonho que aparece em Ham on Rye, ou como diz Eagleton ([1983] 1996), reorganizando o sonho para torná-lo compreensível, há uma possível interpretação: Henry Junior deseja ser abandonado por Deus.

Freud ([1913] 2013, p. 153), ao falar de sociedades patriarcais, alega: "[P]ara cada pessoa o Deus é modelado no pai, que a relação pessoal com Deus depende de sua relação com o pai carnal." Ora, uma vez que Deus, representando oniricamente a autoridade, deixa Henry Junior à mercê do universo, a culpa das agruras que o protagonista sofre não há de ser dele mesmo. Ainda assim, se de acordo com Freud o protagonista deseja ser abandonado por Deus, para Jung, o abandono de Deus é uma compensação para o estado consciente comodista de Henry Junior: “[O] sonho procura assustá-lo para que saia desse estado [...].” (JUNG, [1954] 1988, p. 96). Com essa interpretação dos sonhos, que o autor suíço chama de “construtiva”, a personagem está errada ao achar que está sendo testada por Deus na vida real. Ser abandonado por Deus oniricamente simboliza então o desejo de liberdade inconsciente se manifestando em Henry Junior. Deste modo, o abandono de Deus, representação maior da autoridade, é uma compensação a Henry Junior, pois se a autoridade o deixou, não há necessidade de obedecê-la. Sem a presença da autoridade, ele pode ser livre e independente.

\footnotetext{
87 "All right, God, say that You are really there. You have put me in this fix. You want to test me. Suppose I test You? Suppose I say that You are not there? You've given me a supreme test with my parents and with these boils. I think that I have passed Your test. I am tougher than You. If You will come down here right now, I will spit into Your face, if You have a face. And do You shit? The priest never answered that question. He told us not to doubt. Doubt what? I think that You have been picking on me too much so 1 am asking You to come down here so I can put You to the test!"

88 "GOD HAS FORESAKEN YOU."
} 


\subsection{O inconsciente coletivo e os arquétipos de Jung em Ham on Rye}

C. G. Jung, um dos maiores autores da psicanálise mundial e que inicialmente trabalha com Freud, apreendeu e aprendeu os conhecimentos freudianos, desenvolvendo-os e levandoos a outro patamar. Que há um inconsciente agindo de formas inesperadas e às vezes inexplicáveis, os dois pensadores não discordam. A diferença entre eles se dá na constituição do mesmo. Jung ([1976] 2002, p. 15) afirma que para Freud o inconsciente "é de natureza exclusivamente pessoal", ao passo que aquele afirma que há dentro do inconsciente uma natureza universal. Jung não nega a existência da natureza pessoal do inconsciente: conteúdos reprimidos, esquecidos e outrora conscientes encontram-se represados na psique e cedo ou tarde se manifestam na vida de um indivíduo. O autor suíço, porém, afirma que o caráter pessoal do inconsciente é apenas uma casca, uma camada superficial e finita que encobre uma natureza universal e infinita da psique humana. O humano recém-nascido possui uma psique pré-consciente, não há um vazio, e sim disposições vivas inconscientes.

O inconsciente coletivo é uma camada profunda idêntica em todos os seres humanos segundo Jung ([1976] 2002), é uma herança mítica de nossos antepassados, assim como são os elementos morfológicos do corpo humano. Enquanto que o inconsciente pessoal se constitui de emoções, "os conteúdos do inconsciente coletivo, por outro lado, são chamados de arquétipos [...]" (JUNG, [1976] 2002, p. 16). Arquétipos são imagens universais de origem remota e que acompanham os humanos por toda a história. Porém, essas imagens não são conteúdo, e sim forma. Elas se tornam conteúdo quando preenchidas por experiências individuais, tornando-se assim conscientes. Não há descrição do arquétipo, mas sim uma circunscrição, uma aproximação de seu significado inconsciente. Portanto, ele pode ser somente interpretado. Jung ([1976] 2002) pondera que quaisquer tentativas de explicar um arquétipo são traduções de uma linguagem metafórica que devem levar em conta o seu sentido funcional. Dá-se continuidade ao mito em uma forma moderna. A cada nova geração, novas interpretações para o mito são encontradas a fim de conectar o passado com o presente.

Essas imagens arquetípicas são símbolos do drama humano. Somente para o homem as coisas precisam ser explicadas, na natureza sem o homem não há incompreensão. Jung ([1976] 2002) alega que os pensamentos simplesmente acontecem para o homem primitivo, enquanto na civilização moderna, os sentidos e a consciência progrediram, complexificando a psique humana. Ao tentar interpretar, a natureza é mitologizada pelos homens primitivos como forma de projetar o drama do inconsciente humano em fenômenos naturais. Com o 
progresso científico e da razão, há a separação do mito e do objeto, fruto de um longo processo histórico. Jung ([1976] 2002) pondera que até hoje essas representações coletivas mitológicas estão presentes na sociedade moderna, ora como forma de superstição, ora como as próprias religiões.

Jung, em sua coletânea de ensaios Os arquétipos e o inconsciente coletivo ([1976] 2002), faz um vasto e esmiuçado comentário sobre arquétipos existentes na cultura humana e como são utilizados pela religião como forma de criar muros contra o inconsciente, chamados por ele de dogmas. Todavia, com o desenvolvimento da ciência e filosofia, a razão faz o homem sentir que imagens religiosas são precárias. E, corroborando Benedict Anderson (1983), os males que a religião remediava continuam existindo mesmo sem ela.

O que é preponderante para esta pesquisa, no que se refere a Jung, são os mecanismos utilizados pelos humanos para fugirem de si mesmos, e como os arquétipos presentes no nosso cotidiano nos constituem, nos afetam, ditam atitudes e influenciam valores pessoais. $\mathrm{O}$ indivíduo é formado pelo inconsciente e consciente e se ambos não constituem uma totalidade harmônica, um prejudicará o outro. Jung afirma: “[D]evemos saber quem somos” ([1976] 2002, p. 31) e aceitar que temos problemas é uma forma de sermos honestos e encontrarmos um equilíbrio psíquico. O homem que não quer ou então tem medo de se conhecer faz com que a repressão cresça, dando mais espaço para o inconsciente, prejudicando tanto o consciente quanto a saúde psíquica como um todo provocado pelo desequilíbrio entre id e superego.

Henry Junior tenta, à sua maneira, transformar-se e encontrar a si mesmo em face de vários arquétipos ao longo da narrativa, diferentemente de seu pai. A análise dessas duas personagens, pai e filho, buscando como se dá o encontro e o relacionamento de ambas com os arquétipos, complementa o foco na noção de displaçamento desta pesquisa.

\subsection{Arquétipos e o processo de individuação de Henry Junior}

Em Ham on Rye, Charles Bukowski expõe o tema criança como representação de fragmentação de personalidade ao longo da narrativa. Henry Junior não consegue experimentar a totalidade de sua personalidade, encontrar o "si-mesmo" no âmbito da família tampouco no da nação. No contexto da teoria junguiana, é possível afirmar que Henry Junior se aproxima do conceito de “criança-herói”. De acordo com Jung ([1976] 2002), criança-herói 
é um indivíduo de personalidade fragmentada que enfrenta dificuldades em direção a sua completude. O herói junguiano não é necessariamente definido por grandes feitos, busca por tesouros ou enfrentamentos com ameaças míticas, mas sim por assimilação de conteúdos inconscientes (SHARP, 1991) a fim de trazer a individualidade do sujeito à tona. A personagem enfrenta abandono e perseguições no decurso da infância e da juventude. No caminho em direção a autorrealização, o ambiente externo, representado por comunidades imaginadas, coloca "os maiores e mais diversos obstáculos, dificultando o caminho da individuação" (JUNG, [1976] 2002, p. 167). Segundo Jung ([1976] 2002), o processo de individuação é a maturação da personalidade, um desenvolvimento da psique que se dá ao longo da vida de um indivíduo, estabelecendo um equilíbrio no conflito entre consciência e inconsciência e entre coletividade e individual.

Há vários símbolos representando este confronto em Henry Junior. "O símbolo é a antecipação de um estado nascente de consciência" sustenta Jung ([1976] 2002, p. 169). Para o médico, claridade, luz e dia simbolizam a consciência, enquanto escuridão simboliza o inconsciente. Em Ham on Rye, pode-se ver como se articula tal confronto. Ainda muito pequeno, no jardim de infância, Henry Junior percebe-se rodeado de um ar branco: "Eu sempre sentia como se fosse me enjoar, vomitar, e o ar parecia estranhamente parado e branco [...] Jardim de infância foi no geral ar branco." ${ }^{89}$ (BUKOWSKI, 1982, p. 21). Bukowski se utiliza da cor branca várias vezes na narrativa, constituindo a cor mais vista e citada ao longo do romance. Para falar dos cabelos do avô Leonard: "O cabelo dele era branco puro e longo e sua barba era branca pura e longa" ${ }^{90}$ (BUKOWSKI, 1982, p. 3); para descrever o diretor da escolar quando leva bronca: "Ele era um homem muito digno com uma massa de cabelos brancos"91 (BUKOWSKI, 1982, p. 30); e, quando na sequência é surrado pelo pai por causa da bronca na escola, Henry Junior descreve as paredes brancas do banheiro. Apesar de branco remeter a luz, na infância de Henry Junior esta cor simboliza uma consciência embaçada, ainda não formada, uma luz por vir.

Outros importantes símbolos arquetípicos encontrados na trajetória de Henry Junior são animais, e que, em alguns momentos, conectam-se com a cor branca. Na passagem abaixo, a personagem encontra seus colegas da rua incitando um cachorro a matar um pequeno filhote de gato branco:

\footnotetext{
89 "I always felt as if I was going to be sick, to vomit, and the air seemed strangely still and white [...] Kindergarten was mostly white air."

90 "His hair was pure white and long and his beard was pure white and long."

91 "He was a very dignified man with a mass of white hair."
} 
'VEJAM! ELE CERCOU O GATO! VAI MATÁ-LO!' Havia um pequeno gato branco cercado num canto da parede [...] e o buldogue do Chuck, Barney, estava rosnando e chegando cada vez mais perto. Eu tive a sensação que o gato foi colocado lá pelos caras e que o buldogue foi trazido por eles. [...] Eu pensei em correr, pegar o gato e fugir, mas eu não tinha coragem. Eu estava com medo do buldogue me atacar. Saber que eu não tinha bravura para fazer o que era necessário me fez sentir péssimo. [...] Eu não pude assistir a morte. Senti uma grande culpa em deixar o gato daquele jeito. Havia sempre uma chance de que o gato pudesse escapar, mas eu sabia que eles preveniriam isso. $\mathrm{O}$ gato não estava somente enfrentando o buldogue, estava enfrentando a Humanidade. ${ }^{92}$ (BUKOWSKI, 1982, p. 92-94)

Henry Junior, quando se encontra com a cor branca, uma cor que simboliza a consciência, ele se vê num processo de maturação de personalidade. Um movimento nem sempre claro, porém que ao longo do romance o faz, raramente sem dor, perceber um caminho em direção à sua totalidade. Leonard, o avô de Henry Junior, é visto como um homem bonito e bondoso, ao contrário do que prega o pai. Sr. Knox, o diretor da escola, a princípio classificado como aparentemente um cavalheiro digno, trata Henry Junior da mesma forma que os valentões desonestos da escola. O gato branco, um ser indefeso, é assassinado por puro entretenimento da "Humanidade", sendo que a personagem sente-se triste por estar com medo e sem poder de ação quanto ao destino do gato. Mais uma vez, a personagem está isolada. Mas agora sob uma visão psicanalítica junguiana, o estar sozinho no mundo é equivalente à consciência mais elevada.

$\mathrm{O}$ arquétipo teriomórfico, i.e., em forma de animal, é explicado por Jung da seguinte maneira:

$\mathrm{O}$ arquétipo do espírito sob a forma [...] de animal manifesta-se sempre em situações nas quais seriam necessárias intuição, compreensão, bom conselho, tomada de decisão, plano, etc., que, no entanto não podem ser produzidos pela própria pessoa. O arquétipo compensa este estado espiritual de carência através de conteúdos que preenchem a falta. (JUNG, [1976] 2002, p. 213)

Apesar de espírito ter diferentes definições, Jung trata do termo espírito como uma "antítese entre a vida e a morte" relacionando-o com a psique humana, não totalmente imaterial, mas fisiológico. $\mathrm{O}$ inconsciente chega à consciência por meio de símbolos

\footnotetext{
92 “'LOOK! HE'S GOT THE CAT CORNERED! HE'S GOING TO KILL IT!' There was a small white cat backed into a corner of the wall [...] and Chuck's bulldog, Barney, was growling and moving closer and closer. I got the feeling that the cat had been put there by the guys and then the bulldog had been brought in. [...] I thought of rushing in, grabbing the cat and running, but I didn't have the nerve. I was afraid that the bulldog would attack me. The knowledge that I didn't have the courage to do what was necessary made me feel terrible. [...] The bulldog moved closer. I couldn't watch the kill. I felt a great shame at leaving the cat like that. There was always the chance that the cat might try to escape, but I knew that they would prevent it. That cat wasn't only facing the bulldog, it was facing Humanity."
} 
arquétipos. Um arquétipo teriomórfico significativo para Henry Junior é o cachorro vira-latas. Primeiramente, ele compara o seu colega Baldy, que é rejeitado por todos: "Ele era como um cachorro vira-latas, esfomeado e desprezado. Mesmo assim, não me sentia bem ao lado dele. Mas já que eu conhecia aquele sentimento de cachorro vira-latas, eu o deixei ficar por perto."93 (BUKWOSKI, 1982, p. 99). O fato de ele mesmo se sentir rejeitado faz com que Henry Junior sinta empatia pelo garoto que se parece com um cachorro vira-latas. Posteriormente, a caminho do primeiro dia no primeiro emprego, Henry Junior sente que não está só:

Eu percebi um cachorro vira-latas faminto me seguindo. A pobre criatura era terrivelmente magra; pude ver suas costelas espetando na pele. Maior parte do pelo tinha caído. Restavam pedaços secos e revirados. O cachorro estava espancado, assustado, abandonado, espantado, uma vítima do Homo sapiens. ${ }^{94}$ (BUKWOSKI, 1982, p. 223)

Previamente com um filhote de gato indefeso e depois com um cachorro vira-latas esfarrapado, a personagem observa símbolos teriomórficos como metáforas dele mesmo. Ambos os animais são considerados vítimas dos homens ("Humanity" e "Homo sapiens") pela personagem, assim como ela mesmo se sente em sua vida, uma vítima. Apesar da triste situação dos animais, há indicação de que a culpa da circunstância em que Henry Junior se encontra não é dele mesmo, mas sim do externo, dos homens.

Contudo, ao final do romance, bêbado em seu apartamento, Henry Junior banca o valentão e insulta um casal de idosos. Arrepende-se quase que imediatamente e, neste momento um pequeno gato aparece em sua porta: "Os olhos iluminados pela lua: vermelho puro como fogo." 95 (BUKOWSKI, 1982, p. 309). O diretor da escola, o pai e as crianças da vizinhança sempre bancam os valentões com Henry Junior. A personagem, apesar de condenar tal atitude, vê-se ocasionalmente tendo a mesma reação. Na passagem acima, ao perceber que age como as pessoas que ele maldiz, arrepende-se e se encontra com um arquétipo teriomórfico, simbolizando a vinda de compreensão daquele momento: ao agir irrefletidamente como a coletividade humana, não há equilíbrio.

Desta forma, Henry Junior se depara constantemente com símbolos arquetípicos teriomórficos, imagens míticas que aparecem espontaneamente em sua vida para guiá-lo em

\footnotetext{
93 "He was like a mongrel dog, starved and kicked. Yet it didn't make me feel good going around with him. But since I knew that mongrel dog feeling, I let him hang around."

94 "I noticed a starving mongrel dog following me. The poor creature was terribly thin; I could see his ribs poking through his skin. Most of his fur had fallen off. What remained clung in dry, twisted patches. The dog was beaten, cowed, deserted, frightened, a victim of Homo sapiens."

95 "The eyes were lit by the moon: pure red like fire."
} 
direção a sua totalidade. O confronto junguiano entre a inércia estática da morte e o espírito alado e inspirador está em Ham on Rye. Há, por todo o romance, uma contraposição entre moscas e aranhas, denotando o estado espiritual e psíquico de Henry Junior. Enquanto o pai vocifera denegrindo o próprio irmão John na frente da família, uma mosca entra na casa e perturba a todos. Katherine consegue pegá-la com a mão, para a incredulidade do marido:

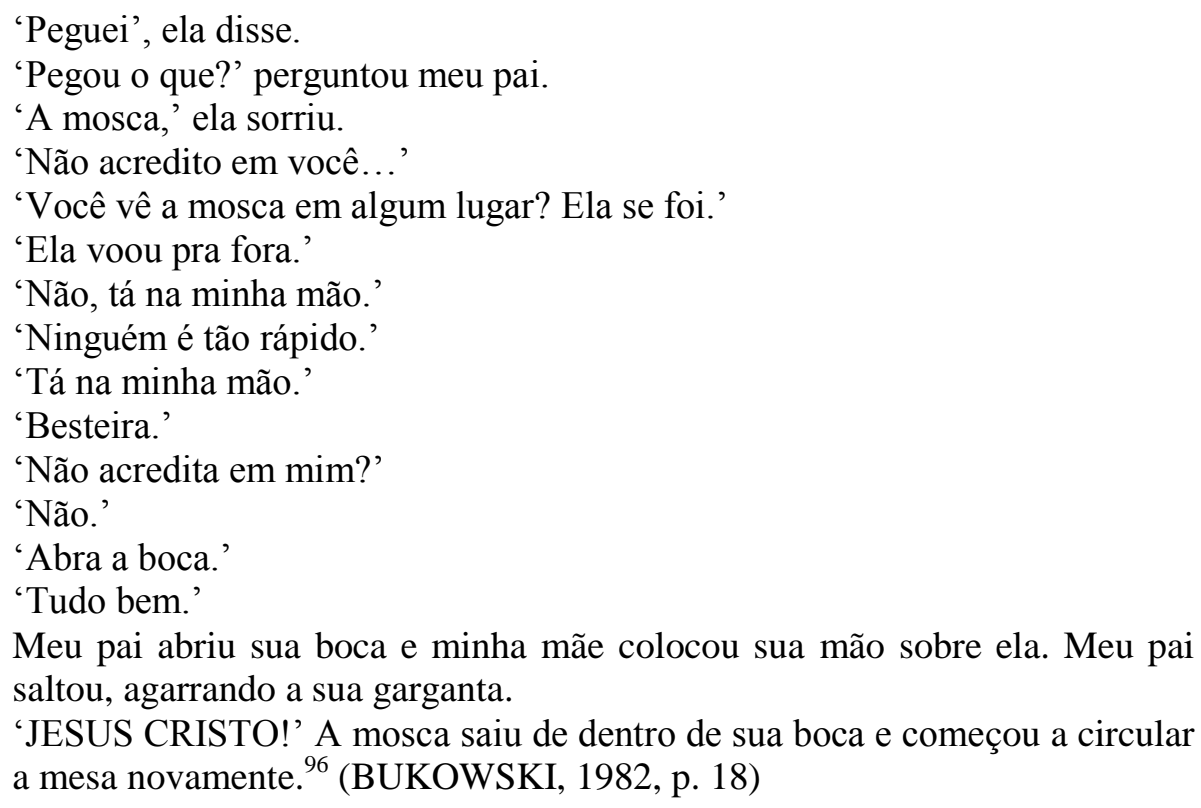

O pai, símbolo primevo de autoridade, está com a dignidade ferida. É a primeira vez na vida que Henry Junior percebe que a autoridade pode ser questionada, confrontada ou mesmo derrotada. E este entendimento é trazido para a personagem por meio do arquétipo do ser alado, no romance representado pelas moscas. Continuemos com estas. Como assinalado, Henry Junior é levado à diretoria injustamente por causa de uma briga na escola. Enquanto Sr. Knox esmaga a mão de Henry Junior como forma de amedrontá-lo e subjugá-lo, este percebe uma mosca voando na sala do diretor e reflete: "[N]ão é tão ruim ser uma mosca."97 (BUKOWSKI, 1982, p. 32). Ao encontrar a injustiça, o arquétipo alado da mosca simbolizando a liberdade aparece para a personagem. Até um inseto tido como desprezível como a mosca tem mais liberdade que Henry Junior. A personagem sente-se como uma mosca presa pela teia da opressão, aprisionada pela inércia.

\footnotetext{
96 “'I got him,' she said. 'Got what?' asked my father. 'The fly,' she smiled. 'I don't believe you ...' 'You see the fly anywhere? The fly is gone.' 'It flew off.' 'No, I have it in my hand.' 'Nobody is that quick.' 'I have it in my hand.' 'Bullshit.' 'You don't believe me?' 'No.' 'Open your mouth.' 'All right.' My father opened his mouth and my mother cupped her hand over it. My father leaped up, grabbing at his throat.

'JESUS CHRIST!' The fly came out of his mouth and began circling the table again."

97 "[I]t's not so bad to be a fly."
} 
Em uma próxima passagem (BUKOWSKI, 1982, p. 90), há o 'embate entre dois arquétipos': os colegas da rua de Henry Junior avistam uma aranha pronta para comer uma mosca, todos estão ansiosos para o momento do abate, quando Henry Junior chuta a teia e estraga tudo para descontentamento geral da turma, que corre atrás dele para surrá-lo. Não coincidentemente, é o mesmo capítulo em que o buldogue mata o filhote de gato. A aranha é um arquétipo teriomórfico que remete à estabilidade e inércia. Como Henry Junior se sente constantemente preso, tal arquétipo causa repulsa por fazê-lo lembrar de como ele mesmo se sente: preso em uma teia. Outro exemplo ocorre na primeira experiência com a bebida alcoólica no porão escuro da casa do amigo Baldy, Henry Junior questiona: "Tem alguma aranha por aqui?" 98 (BUKOWSKI, 1982, p. 100). Como afirma Jung, o escuro representa o inconsciente, e ao descer a um porão escuro, portanto, de encontro ao inconsciente, Henry Junior sente receio de reencontrar o seu arquétipo mais temido.

Ainda tratando de aranhas, outro exemplo é quando adolescente, Henry Junior passa a desenvolver um caso crônico de acne, a ponto de ser hospitalizado. Ao chegar ao hospital público, onde percebe como as pessoas são tratadas com desrespeito e após horas aguardando sem ser atendido, ele analisa a sala de espera: "Havia um buraco negro dividido em duas seções, e parecia que uma aranha havia estado por lá e feito uma teia." ${ }^{99}$ (BUKOWSKI, 1982, p. 139). Ou seja, as aranhas, que são arquétipos de inércia para Henry Junior, aparecem quando há revelações em sua vida, quando há encontros com o inconsciente e quando ele se vê de frente a situações de opressão. A aranha, um símbolo de fixidez e inércia para o protagonista, vai de encontro com a vontade dele de se libertar. E a teia representa a sua condição de subjugado ao passo que moscas representam sua vontade de se desvencilhar da sujeição.

Finalmente, há um embate decisivo com o arquétipo da aranha na narrativa. $O$ protagonista está estudando na faculdade e desgostando da mesma, ele caminha em direção da casa dos pais e se encontra com duas aranhas no caminho e as mata. Sobre sua vida naquelas redondezas, ele pondera:

E ao descer da colina eu trombei com uma teia de aranha gigante. Eu estava sempre fazendo isso. Eu fiquei lá tirando a teia grudenta de mim e procurando pela aranha [...] Eu aprendera a odiar aranhas. [...] Toda a minha vida, naquela vizinhança, eu caminhara em direção a teias de aranha, sendo

\footnotetext{
98 "Are there any spider around here?"

99 "There was a black hole divided into little sections, and it looked like a spider had gone in there and made a spider web."
} 
atacado por gralhas, havia vivido com meu pai. ${ }^{100}$ (BUKOWSKI, 1982, p. 271)

Para Henry Junior, a aranha de fato está na mesma categoria do pai, ambos são opressores. Ao matar as últimas aranhas e se desprender da teia, há uma revelação destes símbolos logo a seguir: o pai Henry Junior descobre que o filho está escrevendo e o expulsa de casa. Fora do mesmo teto do pai, da autoridade, Henry Junior experimenta um pouco de liberdade e o que é estar 'livre de uma teia de aranha' pela primeira vez.

De acordo com Jung ([1976] 2002), as imagens individuais precisam de um contexto. O símbolo arquetípico da aranha e sua teia possuem ligação direta com a figura do pai nas próprias palavras da personagem. $\mathrm{O}$ aracnídeo que vive em lugares escuros em situação inercial, capturando seres alados por meio de teias grudentas, simboliza o pai de Henry Junior o prendendo, impedindo-o de 'voar', de ser livre e de encontrar o equilíbrio entre inconsciente e consciente. E a única forma de se individuar e de alcançar a totalidade é conhecendo a si mesmo, algo que Henry Junior conquista com a ajuda de arquétipos, ora confrontando-os, fugindo deles, admirando-os ou interpretando-os.

\subsection{Projeções e persona}

Diz Jung ([1976] 2002, p. 72): “[P]rojeção é um processo inconsciente automático, através do qual um conteúdo inconsciente para o sujeito é transferido para um objeto, fazendo com que este conteúdo pareça pertencer ao objeto.” Freud ([1913] 2012, p. 62) complementa afirmando que a projeção para o externo ajuda o indivíduo a configurar o mundo externo com elementos do mundo interno, podendo servir "para resolver um conflito emocional [...]". Já persona é um termo muito utilizado por Jung ([1976] 2002) para tratar de uma adaptação ao mundo; a coletividade espera um determinado comportamento de um indivíduo, que por sua vez tenta corresponder ao mesmo. Não é o que a pessoa é, mas sim o que os outros pensam que ela é e, de quando em quando, o que ela pensa que ela é. Esses dois conceitos da psicanálise são encontrados na construção das personagens em Ham on Rye.

\footnotetext{
100 "And as I was coming down the hill I ran into a giant spider web. I was always doing that. I stood there pulling the sticky web from myself and looking for the spider [...] I had learned to hate spiders [...] All my life, in that neighborhood, I had been walking into spider webs, had been attacked by blackbirds, I had lived with my father."
} 
No início do romance, a família Chinaski está a visitar alguns tios de Henry Junior. Ben, que está morrendo de tuberculose, é criticado pelo pai de Henry Junior por seu envolvimento com prostitutas e apostas. John é chamado de desqualificado e sem ambição. Nem o próprio pai, Leonard, escapa das agressões verbais. O pai do protagonista, ao lembrarse da infância, chama aquele de "o homem mais malvado do mundo [...]"101 (BUKOWSKI, 1982, p. 10). Harrison (1994) considera que tal rancor com os irmãos e pai se deve ao fato de terem gasto o dinheiro da família, representando a sua iminente e futura pobreza, uma vez que não há herança a receber. Contudo, parece-me que há mais para se analisar nas atitudes do pai de Henry Junior. Ele desaprova a forma como seus irmãos tratam mulheres e como seu pai era violento com crianças. Porém, conforme mencionado, ele surra brutalmente Henry Junior constantemente e sem razão, repetindo o comportamento que ele mesmo critica. Em certo momento, ele se envolve com uma amante (BUKOWSKI, 1982) e quando Katherine descobre, ainda apanha violentamente sob os ouvidos atentos do filho. Também cabe lembrar como o pai de Henry Junior se julga melhor que os vizinhos e faz de tudo para viver de aparências.

Esta personagem, em termos psicanalíticos, projeta suas deficiências para o externo: critica a violência paterna e bate no filho, chama os irmãos de perdedores ao mesmo tempo em que ele mesmo é um marginalizado social sem chances de alcançar o 'sonho americano'. Há aqui um conflito entre o que o pai de Henry Junior é e o que ele quer e acredita ser. Henry pai se imagina rico, quer passar a imagem de um trabalhador competente e ser respeitado pelos outros. Ele veste a persona do 'americano ideal', representando suas morais e valores. A persona do pai de Henry Junior, ou seja, a de um estadunidense trabalhador, ambicioso e bemsucedido, aparenta ser melhor do que ele realmente é. Portanto, ele se torna obcecado pela sua própria persona, ao mesmo tempo em que projeta suas 'falhas' nos que vivem ao seu redor.

O pai de Henry Junior sempre quis ser engenheiro e finge ser um. Já sabendo que nunca o será realmente, projeta esse desejo no filho, quem nunca teve tal ambição: "Eu arrisco minha vida todos os dias. Por que você deveria ficar de bunda sentada, resmungando? Eu quero que você seja um engenheiro, como diabos você será um engenheiro?" 102 (BUKOWSKI, 1982, p. 163). De acordo com Jung ([1954] 1988, p. 122) ao estudar educação familiar: "[Q]uantas vezes [...] os pais pretendem impor ao filho as próprias ilusões e ambições não realizadas, forçando-o a representar na vida um papel que pode ser

\footnotetext{
101 "the meanest man in the world [...]"

102 "I risk my life every day. Why should you sit around on your ass, moping? I want you to be an engineer. How the hell you gonna be an engineer?"
} 
absolutamente contrário ao desejo dele.” Dessa forma, além de ser um péssimo educador com maus exemplos, o pai de Henry Junior não aceita a própria sombra, ou seja, o lado que não é atrativo em uma pessoa. Sombra para Jung ([1976] 2002, p. 31) é "uma parte viva da personalidade e por isso quer comparecer de alguma forma." Isso acontece no pai da personagem em forma de projeção e obsessão pela própria persona. Henry Junior, ao longo de sua juventude, depois de tanta convivência, sabe quem é o verdadeiro pai, sem as vestes da persona, e isso o fará renunciar a se adaptar ao mundo da forma que o pai faz e recusar ser quem ele não é realmente.

\subsection{A pele como espelho da psique}

O relacionamento dos pais entre eles e a relação deles com os filhos influem diretamente na psique da criança, porém não somente nesta. Ao estudar crianças e o relacionamento com os pais Jung admite que "a criança faz de tal modo parte da atmosfera psíquica dos pais que a dificuldades ocultas aí existentes e ainda não resolvidas podem influir consideravelmente na saúde dela.” ([1954] 1988, p. 115). Ao voltarmos a atenção para Ham on Rye, é importante notar que, além de ser rejeitado pela nação, amigos e família, gerando um imenso senso de não pertencimento, Henry Junior passa a desenvolver um caso crônico de acne quando está no último ano do ensino fundamental: "Muitos dos caras tinham, mas não como a minha. A minha era realmente terrível. Eu era o pior caso na cidade [...] Aconteceu bem quando eu estava começando a ser aceito."103 (BUKOWSKI, 1982, p. 131). A personagem, já marginalizada, sente-se agora um completo pária: "Eu sempre tive problemas com as garotas, mas agora com acne seria impossível." "104 (BUKOWSKI, 1982, p. 131).

Sentindo-se deformado, Henry Junior desiste da prática de educação física no ano seguinte, no ensino médio, por não querer tirar a roupa na frente dos colegas (BUKOWSKI, 1982), isolando-se ainda mais, conforme analisado no capítulo anterior. Henry Junior é frequentemente encarado pelas pessoas por causa de sua acne e ele mesmo concorda com elas: "[...] eu sabia o quão difícil era para as outras pessoas olharem pra mim."105

\footnotetext{
103 "Many of the guys had it but not like mine. Mine was really terrible. I was the worst case in town [...] It happened just as I was beginning to be accepted [...]."

104 "I'd always had trouble with the girls but with acne it was impossible."

105 " [...] I knew how hard it was for other people to look at me."
} 
(BUKWOSKI, 1982, p. 137). Sua situação chega a um ponto em que ele tem que se retirar da escola para um tratamento dermatológico. Depois de ser uma cobaia em um novo procedimento contra acne no hospital onde vai, sua pele não melhora e ele analisa sua própria situação: "Eu frequentemente ficava de frente ao espelho sozinho, perguntando-me o quão feio alguém poderia ser [...] Eu estava horrorizado [...] Eu me senti escolhido, como se eu tivesse sido selecionado para ser daquele jeito."106 (BUKOWSKI, 1982, p. 149).

Acne é conhecidamente um problema de pele que surge na adolescência. Contudo, o caso de Henry Junior parece ser uma exceção. No livro Emotional Disorders in Children and Adolescents: Medical and Psychological Approaches to Treatment (1980) os autores concordam que acne é uma desordem dermatológica "apta a ter mais contribuições hormonais do que psicológicas [...], mas que podem certamente ser afetadas por estas." ${ }^{107}$ (SHOLEVAR et al, 1980, p. 337). Em uma pesquisa feita pela Stanford University em 2003, foi detectada uma piora na acne dos alunos na época de provas, quando eles estavam passando por estresse $^{108}$.

Portanto, para o campo da dermatologia e da psiquiatria, é evidente que a condição emocional do paciente influencia a saúde de sua pele, corroborando a tese de que a personagem Henry Junior tem a sua pele arruinada pelo caos emocional em que vive na narrativa Ham on Rye. O externo, representado pela sociedade e família, repele Henry Junior, afeta o interno, representado pela personalidade do protagonista. Esse conflito gera uma não aceitação por parte de Henry Junior com ele mesmo. Ele é um outsider para os outros, e com o tempo ele concorda com os outros: acha que os pais o adotaram e não o querem mais; acredita que somente os fracos se aproximam dele na escola e na rua. Essa condição de automarginalização social repercute empiricamente no estado físico de Henry Junior e a acne surge como uma materialização da rejeição que ele sofre, aumentando ainda mais o estado de displaçamento da personagem.

\footnotetext{
106 "I often stood in front of the mirror alone, wondering how ugly a person could get [...] I was horrified [...] I felt singled out, as if I had been selected to be this way."

107 "apt to have more hormonal than psychologic contributions [...], but certainly can be affected by them."

${ }^{108}$ Disponível em: <http://www.ncbi.nlm.nih.gov/pubmed/12873885>. Acesso em 15 de fevereiro de 2016.
} 


\subsection{O álcool como remédio}

Bukowski prefigura a futura tendência de Henry Junior ao álcool já no início do romance. Enquanto o pai desdenha dos familiares por serem 'bêbados', Henry Junior discorda, mesmo que de forma inconsciente. Ele descreve o avô, com quem o pai não conversa mais, como "o homem mais bonito que já tinha visto na minha vida."109 (BUKOWSKI, 1982, p. 4). A seguir, a família Chinaski visita Ben, tio paterno de Henry Junior, que está morrendo de tuberculose numa clínica. Mais uma vez, o pai de Henry Junior difama o familiar por causa da bebedeira, porém, ao entrar no quarto, o protagonista se refere a Ben como sendo "um homem muito bonito." o pai dá uma opinião derradeira sobre bêbados: "Eu odeio bêbados! Meu pai era um bêbado. Meus irmãos são bêbados. Bêbados são fracos. Bêbados são covardes."111 (BUKOWSKI, 1982, p. 57). E é em um bêbado que Henry Junior se transforma, denotando uma reação de contraposição ao pai opressor.

Já analisei como o lar se configura como uma dimensão importante na formação da personalidade do protagonista de Ham on Rye. A relação com o pai é preponderante para Henry Junior no que concerne ao estabelecimento de opiniões e do modo de enxergar a vida. Por desenvolver repulsa ao pai, o protagonista frequentemente faz o contrário que o pai faz, tanto como forma de confrontá-lo, como uma maneira de se diferenciar daquele. E em relação ao álcool não é diferente.

O primeiro contato de Henry Junior com o álcool se dá por influência do amigo Baldy. Conforme analisado anteriormente, o porão onde os barris de vinho se encontram é escuro e simboliza o encontro com o arquétipo do inconsciente e a princípio, a personagem se sente receosa. Contudo, após experimentar bebida alcoólica, Henry Junior tem uma revelação: "Nunca me sentira tão bem. [...] Era mágico. Por que ninguém me disse? Com isso, a vida era ótima, o homem era perfeito, nada podia tocá-lo [...] agora eu havia encontrado algo, encontrei algo que vai me ajudar por muito, muito tempo." ${ }^{\prime 12}$ (BUKOWSKI, 1982, p. 101). Posteriormente, quando a bebida já é parte de sua rotina, Henry Junior faz uma análise de

\footnotetext{
109 "the most beautiful man that I had ever seen."

110 "a very handsome man."

111 "I hate drunks! My father was a drunk. My brothers are drunks. Drunks are weak. Drunks are cowards."

112 "Never had I felt so good. [...] It was magic. Why hadn't someone told me? With this, life was great, a man was perfect, nothing could touch him [...] now I have found something, I have found something that is going to help me, for a long long time to come."
} 
como o álcool o ajuda a confrontar o descontentamento com a mesmice: "Eu decidi que eu sempre gostaria de ficar bêbado. Isto eliminava o óbvio e se você conseguisse ficar longe do óbvio o bastante, você mesmo não se tornaria óbvio."113 (BUKOWSKI, 1982, p. 209).

Desta maneira, além de fazer algo que confronta os ideais do pai, Henry Junior encontra um escape para a vida comezinha. Sobre fugir da vida, Freud ([1930] 1997, p. 22) propõe: “A vida, tal como a encontramos, é árdua demais para nós; proporciona-nos muitos sofrimentos, decepções e tarefas impossíveis. A fim de suportá-la, não podemos dispensar medidas paliativas", sendo uma dessas medidas o uso de substâncias entorpecentes. Continua: "[C]om o auxílio desse amortecedor de preocupações, é possível, em qualquer ocasião, afastar-se da pressão da realidade e encontrar, refúgio num mundo próprio.” (FREUD, [1930] 1997, p.26). E isso é claramente o que Henry Junior vislumbra ao experimentar álcool.

\subsection{O desenvolvimento da personalidade de Henry Junior}

Em O desenvolvimento da personalidade ([1954] 1988), Jung continua a análise da psique do ser humano, desta vez com um enfoque maior na infância e na relação da criança e do adolescente com o ambiente familiar e educação escolar, e como tal se articula para influenciar o desenvolvimento da personalidade do indivíduo. Segundo o autor suíço ([1954] 1988), a criança, assim como depende fisicamente dos pais, também depende deles psiquicamente. Portanto, o relacionamento dos e com os pais pode atuar benéfica ou prejudicialmente na formação da personalidade dos filhos. Personalidade, para Jung ([1954] 1988, p. 153), é “afirmação absoluta do ser individual" com "liberdade de decisão própria”, é uma totalidade inatingível do ser humano que "se desenvolve no decorrer da vida" e "somente pela nossa ação é que se torna manifesto quem somos de verdade". O fato de ser inatingível não deve impedir o indivíduo de buscá-la.

Jung ainda afirma ([1954] 1988, p. 46): “[A] consciência se desenvolve a partir de certos começos [...] e não como algo de completo e acabado [e é] na criança que se dá esse desenvolvimento da consciência." O bebê humano possui um estado psíquico animal e começa a ganhar consciência quando percebe o "eu"; na criança "a consciência se vai formando por um agrupamento gradual de fragmentos" (JUNG, [1954] 1988, p. 47) e dessa

\footnotetext{
113 "I decided that I would always like getting drunk. It took away the obvious and maybe if you could get away from the obvious often enough, you wouldn't become obvious yourself."
} 
maneira Jung afirma que os adultos auxiliam a formação da consciência na criança por meio da educação. Entretanto, educação para a liberdade humana é tarefa árdua na opinião do médico suíço: "[N]inguém pode educar para a personalidade se não tiver personalidade" (JUNG, [1954] 1988, p. 152) que parece ser exatamente o caso dos pais de Henry Junior. Dentro de casa, o pai do protagonista não tem uma atitude sincera diante dos problemas da vida, ‘envenenando' psicologicamente o primeiro contato do indivíduo com a coletividade, o ambiente familiar.

Primeiramente na figura dos pais e posteriormente por meio da escola, a criança obtém educação e, nesta passagem, ela pode transferir a imagem dos pais para os professores como símbolo de autoridade. Uma criança que apresenta dificuldade de sociabilidade ao entrar na escola é, de acordo com Jung ([1954] 1988, p. 137), por culpa do relacionamento dos pais, não por alguma característica individual da personalidade: “[A] criança adquiriu em casa certa atitude que a torna inaproveitável para a coletividade [pois] as primeiras impressões recebidas na vida são as mais fortes e as mais ricas em consequências.” No que concerne à escola, Jung ([1954] 1988, p. 51) sustenta que "o mais importante não é abarrotar de conhecimentos a cabeça das crianças, mas sim contribuir para que elas possam tornar-se adultos de verdade" e isso pode ser alcançado com pais psicologicamente preparados juntamente com educadores bem treinados. Em Ham on Rye, não é isso que acontece. Henry Junior, já consciente desta situação, no dia da graduação do ensino médio, reflete sobre a vida escolar até então:

Enfileiramos com nossas becas e chapéus para 'Pompa e Circunstância'. Eu suponho que nos nossos três anos devemos ter aprendido algo. Nossa habilidade para soletrar melhorou e crescemos em tamanho [...] Lá estava eu, Henry Chinaski, turma de 39, indo em direção a um futuro brilhante. Não, sendo conduzido. ${ }^{114}$ (BUKOWSKI, 1982, p. 217)

Se na família é onde alguém deveria encontrar suporte psíquico e afeto, e Henry Junior encontrar mentiras, violência e rejeição, o mesmo vale para a escola, que poderia ser o lugar para "libertar o jovem ser humano de sua identidade com a família e torná-lo consciente de si próprio" (JUNG, [1954] 1988, p. 51), e onde a personagem encontra somente mais 'uma armadilha' irônica da coletividade.

De acordo com Jung ([1954] 1988), as coletividades humanas produzem convenções sociais, que nada mais são do que "necessidades coletivas". O indivíduo que, como o pai de Henry Junior, se sujeita cegamente às convenções, acaba por negar a totalidade, tornando-se

\footnotetext{
114 "We filed in with our caps and gowns to Pomp and Circumstance. I suppose that in our three years we must have learned something. Our ability to spell had probably improved and we had grown in size [...] There I sat, Henry Chinaski, Class of Summer '39, driving into the bright future. No, being driven."
} 
um ser inconsciente e indeterminado, não desenvolvendo assim a sua personalidade: "[A] voz interior é substituída pela voz do grupo social e de suas convenções; em lugar da designação aparecem as necessidades da coletividade.” (JUNG, [1954] 1988, p. 158). Assim sendo, o desenvolvimento da personalidade se dá por meio da necessidade de desprendimento da massa e "fidelidade à sua própria lei". Henry Junior, coagido por diferentes acontecimentos de origem externa e coletiva em sua vida, sente a necessidade de seguir o próprio caminho, que seria diferente do imposto pelas convenções. O preço alto a ser pago é o isolamento.

\subsection{Esconder-se para se encontrar}

Conforme Jung ([1954] 1988), o indivíduo que busca ser livre das leis e métodos impostos pela coletividade humana é um sujeito com características heróico-demoníacas, pois confronta o status quo, gerando antipatia por parte da comunidade, fruto de "um muro de fortíssimos preconceitos a impedir a compreensão" (JUNG, [1954] 1988, p. 158), dado que a massa acredita que desenvolver a personalidade é "viver recolhido em si mesmo, à moda do eremita" (JUNG, [1954] 1988, p. 156), deste modo indo contra aos valores do grupo, gerando impopularidade.

Henry Junior, ao longo do romance, é marginalizado por todos, inclusive pela sua família, e finalmente por ele mesmo. Toda essa segregação constitui o processo junguiano de individuação descrito anteriormente. O protagonista, em conflito com o externo e seguindo a própria lei, sente-se continuamente fraco e desorientado, mas não a ponto de desistir e por exemplo, se matar. No decurso de Ham on Rye (BUKOWSKI, 1982, p. 90-175), há quatro suicídios: do pai do amigo Frank da sua rua; de Harry Walden, um colega bonito que Henry Junior invejava; de um velho doente do hospital que a personagem frequenta para tratar da acne; e do pai de Jimmy, colega da escola. Talvez essas mortes possam ser indicativos de uma possível solução para o displaçamento da personagem, uma vez que pessoas menos marginalizadas que ela não suportaram a vida em sociedade. Entretanto, no último capítulo da narrativa, bêbado, sem emprego e num quarto de pensão, Henry Junior conclui: "Sentado e bebendo lá, eu considerei suicídio, mas eu senti uma estranha afeição por meu corpo, minha 
vida. Desfigurados como eram, eles eram meus."115 (BUKOWSKI, 1982, p. 307). Freud ([1929] 1997) afirma que, assim como há o instinto de viver, há também, explicado pela ação concorrente, o "instinto de morte", originalmente voltado para o externo. Contudo, a civilização reprime a violência, fazendo com que a agressividade se volte para dentro, criando então a vontade de autodestruição, i.e., o desejo de suicídio. Isto posto, em termos freudianos, o suicida é um indivíduo que tem sua agressividade reprimida pela civilização. Já em termos formais do romance, György Lukács (2000) proclama que momentos de morte em uma narrativa são vislumbres do sentido da vida por parte do herói. A morte, representada pelos suicídios, funciona como quebras de monotonia, demonstrações dialéticas de que há saída para as convenções, ou repressões em psicanálise, impostas pela sociedade.

Henry Junior é inicialmente mais uma vítima de restrições impostas pela sociedade. Porém, com o passar do tempo, descrente e cansado das normas coletivas, descarta deslocar seu instinto de agressividade para dentro, rejeitando a solução de autodestruição. O que ocorre de fato é que Henry Junior se sente bem e a vontade quando exterioriza a sua agressividade e aprende que ser valente e feroz é forma de ganhar respeito dos outros. Quando um professor de educação física que desdenha dos alunos desafia um deles para uma luta de boxe e perde, Henry Junior avalia: “[F]oi um dia razoavelmente bom."116 (BUKOWSKI, 1982, p. 119). A agressividade nesta passagem serve como forma de confrontar a autoridade representada pelo professor. Em outro momento, Henry Junior está a praticar boxe com um menino muito mais velho, perde a luta e se machuca todo, no entanto, considera: “[F]oi finalmente um dia bem sucedido"117 (BUKOWSKI, 1982, p. 174) pelo fato de ter ganhado respeito dos que assistiam a luta e por ter conseguido exteriorizar sua agressividade. Esta manifestação de agressividade é uma maneira de ir contra aos preceitos da coletividade. No capítulo já mencionado, no qual os pais estão a compará-lo com um garoto estudioso chamado Mortenson, Henry Junior decide ir à casa dele convidá-lo para jogar beisebol. Durante o jogo, Henry Junior é propositalmente agressivo e por fim acaba quebrando o braço do garoto (BUKOWSKI, 1982). Portanto, a criança que na visão dos pais é um modelo a ser seguido, é atacada fisicamente pelo protagonista, caracterizando mais uma vez a intenção de Henry Junior de não obedecer ou mesmo aceitar as determinações dos pais e da sociedade.

\footnotetext{
115 "Sitting there drinking, I considered suicide, but I felt a strange fondness for my body, my life. Scarred as they were, they were mine."

116 "[I]t had been a fairly good day."

117 "[I]t had finally been a successful day."
} 
No capítulo seguinte ao sonho com Deus, em que 'descobre' que foi abandonado, Henry Junior encontra a vontade e o prazer em se esconder. Ele volta ao hospital para o tratamento de sua acne e os médicos decidem enfaixar a sua cara: "Eu estava escondido. Era maravilhoso. [...] Eu queria que eu pudesse ficar assim pra sempre." ${ }^{118}$ (BUKOWSKI, 1982, p. 157). No dia do baile de formatura, ele pensa consigo mesmo: "Eu não sabia o que eu queria. Sim, eu sabia. Eu queria algum lugar para me esconder, um lugar onde alguém não tivesse que fazer nada." ${ }^{\prime 19}$ (BUKOWSKI, 1982, p. 213). Analisando as possibilidades de vida no último capítulo: "Eu mesmo assim sabia, como eu soube quando criança, que havia algo estranho em mim. Eu sentia que estava destinado a ser um matador, um ladrão de banco, um santo, um estuprador, um monge, um eremita. Eu precisava de um lugar isolado para me esconder." ${ }^{120}$ (BUKOWSKI, 1982, p. 307). Segundo Freud ([1929] 1997, p. 26-30): “[C]ontra o sofrimento que pode advir dos relacionamentos humanos, a defesa mais imediata é o isolamento [...] o eremita rejeita o mundo e não quer saber de tratar com ele." Quaisquer caminhos que pessoas pertencentes à coletividade escolham são sumariamente refutados por Henry Junior, seja ter emprego e acumular como o pai quer, seja se suicidar como outros decidiram ou então viajar para ter novas ideias como o único amigo sugere. Ele se sente diferente e passa a aceitar a sua condição, resolve seguir a sua designação e a sua própria lei, estabelecendo a resistência pela fixidez, desenvolvendo assim a sua personalidade.

O objeto, ou seja, o externo representado pelas diversas esferas da coletividade humana, não é claro para Henry Junior. A princípio ele enxerga uma neblina o cercando na infância. A iluminação que eventualmente o leva mais perto de sua totalidade é alcançada por constantes conflitos com o ambiente. Esse conhecimento de conteúdo universal tem relação dialética com o individual, ambos se influenciando mutuamente. As convenções vindas do externo tornam-se algo que Henry Junior não aceita, daí a fonte da "necessidade" junguiana. No caso da personagem, necessidade de não seguir tais convenções. O sonho com Deus o abandonando é uma manifestação da voz interior de Henry Junior. Segundo Jung ([1954] 1988, p. 165): “[A] voz interior é a voz de uma vida mais plena e de uma consciência mais ampla e abrangente" sendo que "o homem deformado pela cultura é de todo incapaz de perceber essa voz.” (JUNG, [1954] 1988, p. 164). O abandono de Deus, assimilado

\footnotetext{
118 "I was hidden. It was wonderful. [...] I hoped I could stay this way forever."

119 "I didn't know what I wanted. Yes, I did. I wanted someplace to hide out, someplace where one didn't have to do anything."

120 "I still knew, as I had as a child, that there was something strange about myself. I felt as if I were destined to be a murderer, a bank robber, a saint, a rapist, a monk, a hermit. I needed an isolated place to hide."
} 
conscientemente por Henry Junior, significa liberdade da rotina, da cultura e das leis da coletividade.

\subsection{A arte como sublimação contra o displaçamento}

Em concordância com o que Freud ([1929] 1997) afirma sobre a relação dos indivíduos com a sociedade, ainda há outra possível técnica para escapar do sofrimento provocado por tal relação: a sublimação. Esse mecanismo de defesa da mente humana se constitui em um deslocamento da libido: impulsos inconscientes são integrados na personalidade culminando em atitudes de valor socialmente aceitos, como por exemplo, atividades artísticas. A libido, representada na psique humana pelo id, devido ao seu caráter instintivo e inconsciente, busca incessantemente a satisfação. A organização coletiva dos humanos, em virtude do seu caráter repressivo, entra em conflito com os desejos individuais, coibindo-os, transformando a realidade em algo penoso.

Para Freud (1908), tanto as brincadeiras de criança, as fantasias, os sonhos quanto as obras de arte são formas de fugir da realidade desprazerosa. No começo, a criança fantasia e brinca, para depois quando adulto, sonhar e eventualmente criar arte. Henry Junior é rechaçado pelos colegas da prática de beisebol e futebol americano na escola, e no capítulo seguinte apanha pela primeira vez do pai. Sentindo-se excluído na escola e no lar, ele imediatamente começa a devanear:

Uma coisa que eu imaginava era que eu era um grande jogador de beisebol, tão bom que eu podia acertar a bola ou um home run quando eu quisesse [...] Era temporada de futebol americano e eu era - na minha imaginação - um ótimo quarterback. Toda hora que eu pegasse a bola eu corria até o touchdown. Como o público gritava! ${ }^{121}$ (BUKOWSKI, 1982, p. 38-40)

Para o protagonista, a imaginação não é só uma fuga do desprazer em termos freudianos, mas é nítida compensação junguiana. Displaçado na vida concreta, Henry Junior encontra reconhecimento e aceitação em seus devaneios.

Conforme assinalado anteriormente, o pai de Henry Junior o proíbe de assistir o discurso do presidente. Sendo obrigado a fazer o dever de casa, ele escreve um relatório

\footnotetext{
121 "One thing I imagined was that I was a great baseball player, so great that I could get a hit every time at bat, or a home run anytime I wanted to [...] It was football season and I was - in my imagination - a great quarterback. Every time I got the ball I ran all the way to a touchdown. How the crowd screamed!"
} 
fictício e a professora, mesmo sabendo da invenção, lhe dá nota máxima pelo fato da redação ser tão bem-feita. Ele então tem um insight: "Então, era isso que eles queriam: mentiras. Belas mentiras. Era o que eles precisavam. As pessoas eram tolas. Iria ser fácil pra mim [...] As coisas estavam melhorando." 122 (BUKOWSKI, 1982, p. 87). No primeiro contato com a ficção, Henry Junior descobre um caminho para a vida e conquistar alguma consideração das pessoas. No capítulo seguinte em que tem a cara enfaixada, ele reencontra a escrita. Começa a escrever sobre Barão Von Himmlen, um valente aviador alemão da Primeira Guerra, feio e bêbado, a quem todos temiam e respeitavam, mais uma clara demonstração de necessidade de compensação. Acerca de sua personagem e da ficção, Henry Junior pondera: "Me fazia bem escrever sobre o Barão. Um homem precisava de alguém. Não havia ninguém por perto, então você tinha que inventar alguém, inventá-lo do jeito que um homem deveria ser."123 (BUKOWSKI, 1982, p. 161). Segundo Freud (1908, p. 421), o escritor faz o mesmo que a criança: "[E]le cria um mundo de fantasia que ele leva muito a sério, no qual investe grande quantidade de emoção" ${ }^{\prime 24}$ e que tem ligação com uma experiência forte da vida real. O escritor supera o sentimento interno de repulsa por meio de fantasias. A repulsa que Henry Junior sente por si mesmo pelo fato de ser feio e marginalizado é aliviada pela personagem do Barão. Ou a criação do Barão compensa os sentimentos conscientes da personagem. Aqui também se pode observar um primeiro indício da presença da contraposição aristotélica entre história e ficção, no caso de Henry Junior, a ficção como uma forma de mudar a sua própria história.

O conforto contra a repressão provocado pelo contato com a obra literária não se dá somente pela produção, mas também pela leitura: “[N]ossa real apreciação por uma obra imaginativa vem de uma liberação de tensões em nossas mentes."125 (FREUD, 1908, p. 428). Após ter a cara enfaixada, Henry Junior tem o tratamento contra acne encerrado e é obrigado a voltar para a escola. Descobre então, mais um local onde pode sublimar seu displaçamento: uma biblioteca pública que passa a frequentar diariamente. Sobre os livros que lá encontra, pondera: "Palavras não eram embotadas, palavras eram coisas que poderiam fazer sua mente zumbir. Se você as lesse e se deixasse sentir a mágica, você poderia viver sem dor, com

\footnotetext{
122 "So, that's what they wanted: lies. Beautiful lies. That's what they needed. People were fools. It was going to be easy for me [...] Things were looking up."

123 "It made me feel good to write about the Baron. A man needed somebody. There wasn't anybody around, so you had to make up somebody, make him up to be like a man should be."

124 " $[\mathrm{H}] \mathrm{e}$ creates a world of phantasy which he takes very seriously, which he invests with large amounts of emotion."

125 "[O]ur actual enjoyment of an imaginative work proceeds from a liberation of tensions in our minds."
} 
esperança, não importando o que acontecesse contigo."126 (BUKOWSKI, 1982, p. 165). Com o apoio de seu novo hobby, de seu novo ofício literário e do álcool, Henry Junior encontra certo conforto contra o displaçamento exterior, interno e contra a solidão. Apesar do 'eu' fragmentado na infância e dos traumas sofridos, a intoxicação e a arte, representando respectivamente fuga e esperança, guiam a personagem em direção à totalidade e ao desenvolvimento de personalidade, ainda que de maneira atípica.

Terry Eagleton ([1983] 1996), ao problematizar o prazer e o gosto pessoal dentro da crítica literária, conclui que a análise psicanalítica da literatura trouxe tais questões para dentro da crítica pelo fato delas serem elementos complexos. Fuga da dor e busca do prazer, sob uma visão rasa, podem parecer simples hedonismo, mas são muitas vezes, uma questão de sobrevivência humana, constituindo-se então, um sentimento com dimensões ideológicas e políticas. Eagleton ([1983] 1996, p. 185) chama literatura de "sistema significante" que produz um efeito ideológico e atesta: "Você pode querer montar suas próprias práticas significantes para enriquecer, combater, modificar ou transformar os efeitos que as práticas dos outros produzem." ${ }^{127}$ Em Ham on Rye, Henry Junior sente muitos desprazeres em contato com a sociedade em que vive, sendo reprimido constantemente pelo externo. O prazer que a personagem encontra na arte literária, ora lendo, ora escrevendo, desvenda outro sistema significante que combate o que é posto pela sociedade estadunidense, mostrando-lhe um caminho em direção à completude perdida e ao desenvolvimento de sua personalidade, algo que qualquer médico psicanalista certamente afirmaria ser saudável para um indivíduo.

Henry Junior, portanto, é um sujeito que questiona a sociedade patriarcal e diferentes formas de autoridade repressora presente na civilização e que não enxerga nenhum futuro promissor no destino oferecido a todos por meio de emprego, religião e família. Ao conceber isolamento, intoxicação e arte como soluções plausíveis ao seu displaçamento, buscando uma psique saudável da sua maneira, Henry Junior nega as convenções coletivas, indo contra o que a ideologia dominante prega, levando-nos ao próximo capítulo.

\footnotetext{
126 "Words weren't dull, words were things that could make your mind hum. If you read them and let yourself feel the magic, you could live without pain, with hope, no matter what happened to you."

127 "You may want to stage your own signifying practices to enrich, combat, modify or transform the effects which others' practices produce."
} 


\section{UM CONTRA TODOS}

I didn't have a job, I didn't go to school. I didn't do anything. I wasn't going to suicide. I'd rather kill some of them.

(Henry Junior)

\subsection{Mapeando as aflições ${ }^{128}$ em Ham on Rye}

Tenho discutido como a coletividade, representada pela sociedade estadunidense em todas as suas dimensões, marginaliza a personagem Henry Junior por não se enquadrar nos padrões ditos aceitáveis. Tanto a nação como a família pregam e exigem determinado comportamento por parte de seus integrantes para que elas perdurem. Um indivíduo que aja de forma não condizente com as 'normas' coletivas tende a ser excluído, sofrendo um displaçamento, como é o caso do protagonista de Ham on Rye. De uma abordagem sociológica, no segundo capítulo, passo para uma psicanalítica no subsequente a fim de entender os efeitos negativos que a exclusão social provoca em Henry Junior, e como este absorve, tenta entender e finalmente, reage a eles.

Independentemente dos capítulos anteriores se valerem de abordagens teóricas distintas, algo os une: o atrito produzido pela dialética sujeito-objeto. A dialética pode ser definida como uma relação tensionada entre opostos, e há de se pensar tais partes em relação com o todo, e o todo em relação com as partes (CORRÊA; HESS, 2011). A comunidade imaginada nação e a família, esta a serviço da comunidade imaginada nacional, articulam ideologicamente o poder da união como forma de manter o status quo. Os integrantes que compactuam com a ideia de comunidade, ao julgarem alguém como não pertencente a ela, tentam excluí-lo, separando-o do todo, gerando uma tensão dialética entre coletividade e individual. Assim como nos capítulos anteriores, de abordagens sociológica e psicanalítica, neste capítulo também não é possível analisar sujeito e objeto separadamente.

Basicamente, a exclusão de um sujeito não afetará somente ele, mas também o objeto, e este, tendo mudado, voltará ao sujeito em um processo contínuo. Isso se dá em todas as

\footnotetext{
${ }^{128}$ Expressão cunhada pelo professor Hermenegildo Bastos (2011).
} 
dimensões já analisadas na narrativa: lar, escola, empresa e nação. O sujeito Henry Junior sofre diversas aflições durante sua vida: é pobre, feio, não tem namorada, possui poucos amigos, é carente de amor dos pais e é um imigrante marginalizado devido ao seu local de nascença. Tais aflições individuais serão agora analisadas dialeticamente em relação com a coletividade, juntamente com respectivas reverberações na vida da personagem de Ham on Rye, em sua família e na sociedade estadunidense.

\subsection{Conflito de classes em Ham on Rye}

Momentos históricos significativos como Revolução Francesa, Independência dos EUA, Grandes Guerras do século XX e a crise de 1929, bem como importantes fenômenos sociais como formação da nação, do nacionalismo e imigração respaldam esta dissertação e servem como arcabouço para que eu chegue a conclusões sobre o contexto social retratado por Ham on Rye. Sob a ótica histórico-materialista de Karl Marx, os eventos acima são de alguma forma frutos do conflito de classes, que se configura, de uma forma simplificada, em uma manifestação de antagonismos gerada pela posse e a não posse de bens materiais (ABBAGNANO, 2007; BOUDON, 1990). Dentre as diferentes formas de displaçamento social que um indivíduo pode sofrer, um modo intrínseco de uma sociedade capitalista e que é bastante evidente na narrativa estudada é a precariedade financeira. A classe social desfavorável de Henry Junior é invariavelmente uma fonte de discriminação, especialmente em uma sociedade fetichizada como a dos EUA.

A partir de entendimentos sobre o materialismo histórico, aplicá-los-ei na “identificação da estrutura da realidade" em Ham on Rye para que consigamos compreender melhor como as contradições de uma sociedade capitalista se articulam tanto no romance, quanto fora dele. Para tanto, Frederick Engels (1880) explica:

O conceito materialista de história começa com a premissa de que a produção dos meios para sustentar a vida humana e, ao lado da produção, a troca das coisas produzidas, é a base de toda a estrutura social; que em toda sociedade que apareceu na história, a maneira que a riqueza é distribuída e a sociedade é dividida em classes ou ordens é dependente do que é produzido, como é produzido, e como os produtos são trocados. Deste ponto de vista, as causas finais de todas as mudanças sociais e revoluções políticas devem ser procuradas, não na cabeça dos homens, não em melhores visões do homem 
sobre verdade eterna e justiça, mas em mudanças nos modos de produção e troca. $^{129}$

É sabido que o mundo objetivo existe independentemente da consciência humana e que a recíproca não é verdadeira. O homem, ao ganhar consciência de si, age sobre a natureza, não simplesmente se adaptando a ela, mas constituindo-a como objeto. Ao agir, ou melhor, ao trabalhar, os homens reduzem as barreiras naturais, ao mesmo tempo em que melhoram e aumentam os meios de produção, e assim evoluindo, porém, nunca retilineamente e sem contradições.

O homem trabalhando produz valor, e este é socializado. À medida que a sociabilidade cresce, há uma crescente necessidade de se controlar a propriedade e regular a apropriação de valores. É o embrião da divisão do trabalho. O Capitalismo, como forma política de governo, estabelece como parâmetros de sua existência a propriedade privada e a divisão do trabalho. $\mathrm{O}$ trabalho, que é inicialmente um provedor de liberdade, é apropriado e serve à produção em massa, na qual o homem cessa sua identificação com os objetos que produz (LUKÁCS, 2003). Com uma violenta produção de valor e ausência de identificação com o trabalho, há como resultado uma grande fonte de estranhamento. Aqui, há o que Marx (1844) preconiza como a evolução humana superando estranhamentos e produzindo outros.

O materialismo histórico marxista trata do Capitalismo e de suas consequências como uma fase da evolução humana a ser superada. Além do desenvolvimento técnico e produção de valor, no mundo moderno há um senso-comum, conforme Celso Frederico (2013), sobre o "positivismo", conceito que afirma que a "realidade se confunde com sua manifestação imediata". A dialética marxista nega a imediatez da mercadoria e de seu positivismo raso para concluir que ela é simplesmente um valor, algo produzido pelo homem. O fruto de intensa imediatez e dessa "evidência empírica" é uma realidade falsa, um "fetichismo da mercadoria". As mercadorias e as coisas parecem ser a realidade que aparenta ser regida por elas, bem como os indivíduos, que são qualificados de acordo com a quantidade de valor que eles conseguem produzir (LUKÁCS, 2009) ou meramente com a quantidade de mercadorias que possuem. Para Marx (1844), essa "representação caótica da realidade" esconde os "vestígios humanos da sociedade", fazendo com que os indivíduos se relacionem uns com os outros

\footnotetext{
129 "The materialist conception of history starts from the proposition that the production of the means to support human life and, next to production, the exchange of things produced, is the basis of all social structure; that in every society that has appeared in history, the manner in which wealth is distributed and society divided into classes or orders is dependent upon what is produced, how it is produced, and how the products are exchanged. From this point of view, the final causes of all social changes and political revolutions are to be sought, not in men's brains, not in men's better insights into eternal truth and justice, but in changes in the modes of production and exchange."
} 
como portadores de mercadoria, gerando uma sociedade 'reificada', ou 'coisificada', e consequentemente, desumanizada.

A sociedade burguesa, ao amadurecer, perde o seu caráter progressista que vem da Revolução Francesa (LUKÁCS, 2009) alienando por completo os trabalhadores; tudo se torna quantificável, inclusive as qualidades. O fetichismo, apesar de uma ilusão, é tido como real. Essa alienação, ou reificação, nas palavras de Lukács (2011, p. 96), é explicada da seguinte forma:

\begin{abstract}
A economia marxista, com efeito, faz com que as categorias do ser econômico (do ser que constitui o fundamento da vida social) sejam derivadas das manifestações de suas formas reais, isto é, como relações entre homens e homens e, por meio destas, como relação entre sociedade e natureza. Mas, ao mesmo tempo, Marx demonstra que, no Capitalismo, todas essas categorias aparecem necessariamente numa forma reificada; e por causa dessa forma reificada, ocultam a verdadeira essência, ou seja, a de relação entre os homens. Nessa inversão das categorias fundamentais do ser humano reside a fetichização inevitável que ocorre na sociedade capitalista. $\mathrm{Na}$ consciência humana, o mundo aparece completamente diverso daquilo que na realidade é: aparece deformado em sua própria estrutura, separado de suas efetivas conexões. Torna-se necessário um peculiar trabalho mental para que o homem do Capitalismo penetre nesta fetichização e descubra, por trás das categorias reificadas (mercadoria, dinheiro, preço, etc.) que determinam a vida cotidiana dos homens, a sua verdadeira essência, isto é, a de relações sociais entre os homens.
\end{abstract}

Terry Eagleton (1991) complementa a ideia acima ao dizer que a consciência está ligada à prática social, mas com a alienação provocada pelo Capitalismo, há uma cisão, as coisas materiais parecem ter vida própria e ser a fonte natural da história. O próprio Henry Junior padece de alienação. Quando entra no ensino médio, para o qual vai de bicicleta, a personagem percebe que muitos dos outros estudantes possuem carros, o que o faz sentir uma vergonha terrível a ponto de ele preferir ir a pé a mostrar aos outros que não possui um veículo automotor (BUKOWSKI, 1982). Neste ponto da narrativa, apesar do protagonista já deter certo conhecimento sobre os efeitos da reificação em um indivíduo, fruto da convivência com o pai, isso não o impede de sentir vergonha em não possuir um automóvel, simbolizando o conflito entre consciência e prática social e os efeitos desumanizadores da reificação. Ou seja, ele como não portador de mercadoria se sente um humano inferior, e isto o caracteriza como mais uma vítima da reificação.

No representativo e já analisado capítulo de Ham on Rye em que Henry Junior encontra o primeiro emprego como estoquista de uma loja de departamentos, há mais um exemplo dos efeitos da reificação no protagonista. Ao desgostar de como era tratado pelos seus superiores, a personagem caminha sozinha e recorre ao habitual monólogo interno: 
O sistema de castas era um fato aceito. Não havia um só vendedor que falasse com um estoquista a não ser por uma ou duas palavras superficiais. E isso me afetava. Eu pensava a respeito enquanto empurrava meu carrinho. Seria possível que os vendedores fossem mais inteligentes que os estoquistas? Eles certamente se vestiam melhor. Me incomodava que eles assumissem que o posto deles significava tanto. Talvez se eu fosse um vendedor, eu me sentiria da mesma forma. ${ }^{130}$ (BUKOWSKI, 1983, p. 233)

O fato dos vendedores receberem um salário maior que o de Henry Junior faz a personagem compreender que a atitude esnobe dos vendedores está ligada ao maior poder de compra e que esse componente material está de alguma forma ligada a uma maior inteligência, evidenciando o imediatismo na visão do protagonista. Assim como o pai e os pares do trabalho, Henry Junior se encontra mais uma vez ameaçado pela reificação. Desgosta do fato de não possuir bens materiais e de ser tratado da forma que é pelos que os têm. Contudo, quando tenta analisar mais profundamente do porque da atitude dos outros, ele chega à triste conclusão de que talvez ele repetisse tal atitude, salientando que todos estão à mercê da reificação, mesmo Henry Junior, um sujeito que busca escapar das convenções da sociedade.

Uma vez mais, articulações de poder estão sendo abordadas, e fatores histórico-sociais ajudarão a respaldar esta pesquisa. Em concordância com a minha análise, a narrativa se passa no entre guerras (1919-1939) nos Estados Unidos da América. Apesar da catástrofe humana que é a Primeira Grande Guerra, os EUA saem como grandes salvadores e vencedores, catapultando-os para o posto de país mais poderoso do globo. Essa ascensão é nítida na transformação do país (TINDALL, 1984) com energia elétrica ao alcance de todos, pleno emprego e produção em massa de carros baratos: os roaring twenties são um momento de afirmação dos EUA como locomotiva do Capitalismo mundial. Porém, como não pode deixar de ser sob o ponto de vista dialético, a evolução humana nunca é linear e a produção em massa estadunidense e a crescente acumulação de capital, bases do Capitalismo, são grandes fontes de estranhamento e acabam mal em 1929.

Ao citar novamente estranhamento, estou falando de reificação de Lukács ([1923] 2003), ou fetichismo para Marx (1844). Devido ao Capitalismo avançado no entre guerras, a sociedade estadunidense vive sob efeitos de extrema reificação. $O$ mesmo se sucede na década de 80, época em que Charles Bukwoski escreve Ham on Rye. A fragmentação da

\footnotetext{
130 "The caste system was an accepted fact. There wasn't a single salesclerk who spoke to a stock-clerk outside of a perfunctory word or two. And it affected me. I thought about it as I pushed my cart about. Was it possible that the salesclerks were more intelligent than the stockclerks? They certainly dressed better. It bothered me that they assumed that their station meant so much. Perhaps if I had been a salesclerk I would have felt the same way."
} 
experiência social provocada pela reificação desumaniza o proletariado, que não consegue enxergar mais a sociedade como um processo coletivo. Segundo Lukács ([1923] 2003), o proletariado precisa alcançar um conhecimento emancipador para poder mudar esta condição. Chegando-se mais perto da totalidade, será permitida uma restauração e uma transformação humanizante. Sob esse ponto de vista, Henry Junior é um proletário inicialmente perdido e desumanizado em busca do autoconhecimento que o ajudará no desenvolvimento de uma consciência política.

Se no capítulo anterior desta dissertação analiso a tentativa de Henry Junior alcançar a totalidade equilibrando as tensões entre o consciente e o inconsciente, neste, perante a dialética marxista, examino como ele procura abarcá-la por meio de uma práxis política, mesmo que não seja totalmente clara para ele. De acordo com Lukács ([1923] 2003) e Eagleton (1991), essa emancipação política pode se dar por meio da dialética. A ideologia capitalista reproduz uma visão imediatista e consequentemente limitada da realidade, e a dialética faz com que percebamos as contradições da história, permitindo-nos desvendar a verdade que está contida, porém escondida, no todo.

Henry Junior nasce um integrante da classe proletária, e ao longo de sua jornada em busca da totalidade, adquire uma consciência de classe, o que o faz perceber as relações reificadas entre os indivíduos, e como estes se relacionam como 'portadores de mercadoria'. A verdade não é alcançada por meio de contemplação, mas sim de maneira dialética (LUKÁCS, [1923] 2003). Nas próximas seções, veremos como a dialética de Henry Junior funciona e como ele adquire a sua consciência de classe, fazendo-o entender melhor a construção da história e a buscar uma saída plausível para o seu displaçamento.

\subsection{Ham on Rye como crítica a ideologia}

No livro Ideology (1991), Terry Eagleton faz um extenso estudo sobre como o termo ideologia tem diferentes definições e usos através da história. Explorando diversos autores de diferentes épocas, Eagleton elabora um mapa teórico-histórico sobre o tema, nunca deixando de expressar a sua vertente marxista. Interessa a esta dissertação o que o crítico conclui ao fim do livro: "Ideologia [...] representa os pontos onde poder impacta sobre certos enunciados e 
inscreve-se tacitamente dentro deles"131 (EAGLETON, 1991, p. 223), ou como atesta na conclusão de Literary Theory: "Certamente 'ideologia' pode ser tida para indicar não mais que essa conexão - a ligação ou nexo entre discursos e poder."132 (EAGLETON, [1983] 1996, p. 183). No caso de Ham on Rye, o poder é representado pelas dimensões da coletividade e pelos respectivos discursos em que Henry Junior se vê face a face ao longo da juventude.

Analisando ideologia em termos de discurso, Eagleton (1991) estabelece que enunciados podem ser empiricamente verdadeiros, porém há de se entender as circunstâncias em que tais enunciados foram pronunciados, pois o contexto, ou em termos marxistas, a base sócio-material, há de gerar implicações para quaisquer afirmações. Um exemplo preponderante disso a este estudo é quando Eagleton demonstra que uma obra literária possui declarações empíricas, mas o que importa é o efeito que a integração destes elementos produz: “[V]erdades empíricas são organizadas como componentes de uma retórica geral. Se essa retórica exigir, uma verdade empírica em particular pode ser moldada em falsidade."133 (EAGLETON, 1991, p. 22). A maneira que o conjunto dos elementos empíricos é organizado reflete a "visão de mundo" ou então o "estilo de percepção" de uma coletividade ou de um indivíduo. Dialeticamente, o discurso é uma prática social que não apenas reflete ou apresenta as relações sociais, mas também as constrói.

Transpondo essa ideia para Ham on Rye, tem-se no início do romance o pai de Henry Junior depreciando o irmão John: "Se este país estivesse cheio de homens como ele, os chinas assumiriam o comando e nós que conduziríamos as lavanderias [...]."134 (BUKOWSKI, 1982, p. 13). De acordo com a página eletrônica Immigration to the United States ${ }^{135}$, as lavanderias se tornaram a principal ocupação dos chineses nos EUA desde a primeira leva de imigração. Ou seja, o discurso do pai de Henry Junior contém um dado empírico. No entanto, ele se utiliza deste como forma de menosprezar a ocupação dos imigrantes chineses, sendo que a própria esposa é uma imigrante e ele mesmo é filho de um. A mensagem transmitida está em discrepância com o que é vivido e Eagleton (1991) chama isso de "contradição performática". A declaração do pai de Henry Junior, organizada com base em elementos empíricos, é clara: mesmo sendo imigrantes como os chineses, nós somos melhores que eles. Esta mensagem

\footnotetext{
131 "Ideology [...] represents the points where power impacts upon certain utterances and inscribes itself tacitly within them."

132 "Indeed 'ideology' can be taken to indicate no more than this connection - the link or nexus between discourses and power."

133 “[E]mpirical truths are organized as components of an overall rhetoric. If that rhetoric seems to demand it, a particular empirical truth may be bent into falsehood."

134 "If this country was full of men like him the Chinks would take over and we'd be running the laundries [...]."

${ }^{135}$ Disponível em: <http://immigrationtounitedstates.org/>. Acesso em 25 de julho de 2016.
} 
racista de brancos melhores que orientais remete à problematização de Avtar Brah (1996) de que minorias são constituídas e posicionadas em relação a outras minorias. Eagleton (1991, p. 51) afirma: "Interesses podem interferir no nosso conhecimento, no sentido, por exemplo, que explicar a situação verdadeiramente pode não ser do meu interesse." ${ }^{136}$ O pai de Henry Junior manipula dados empíricos motivado pelo interesse de ser, sentir-se e se mostrar superior. Este mesmo interesse o impede de ver uma realidade óbvia: de que ele e os chineses estão exatamente na mesma posição.

Se no capítulo passado, concluí que o pai de Henry Junior, em termos psicanalíticos, se torna obcecado pela sua própria persona por não aceitar ser quem é realmente, aplicando o estudo de ideologia, complemento ao afirmar que ele é uma vítima da legitimação da ideologia do sonho americano. Mas por ser uma vítima e não lutar contra isso, ele acaba por servir ao status quo e se torna um propagador desta mesma legitimação. Frederico (2013, p. 164-165) nos fornece uma valiosa contribuição analítica sobre como a legitimação no plano ideológico se articula:

Antes de expressar-se em esferas mais complexas (arte, direito, etc.), a ideologia brota na ontologia da vida cotidiana como uma reação do homem ao ambiente socioeconômico [...], significa uma resposta para os problemas imediatos postos pela realidade social. [...] Os germes dos conflitos entre a comunidade e os indivíduos foram-se explicitando pouco a pouco com o desenvolvimento social, e, concomitantemente, a tendência de impor o interesse particular como se fosse o universal - característica básica do fenômeno ideológico - foi-se articulando, com intensidade crescente, à dominação social.

O ‘sonho americano', um conceito ideológico da sociedade capitalista estadunidense, é legitimado, ou seja, naturalizado, tornando-se forçadamente um sonho de todos que queiram fazer parte da nação. O pai de Henry Junior, um indivíduo inserido e submisso à ideologia dominante, não enxerga os limites dela, passando a sempre acreditar em suas próprias ações, mesmo elas estando em contradição com sua situação real. Conforme dito, o 'sonho' é inalcançável para a maioria das pessoas, inclusive para a família Chinaski, mas o pai de Henry Junior, em vez de adquirir uma consciência de classe e tentar enxergar de alguma forma as contradições postas pela sociedade e quem sabe, tentar mudá-las, torna-se um indivíduo angustiado e sem atitude. Se, de acordo com Jung, o pai de Henry Junior é um indivíduo de personalidade não desenvolvida, para Friedrich Nietzsche (2015), pode-se chamá-lo de "personalidade fraca".

\footnotetext{
136 "Interests may interfere with our knowledge, in the sense, for example, that to understand the situation truly may not be in my interests."
} 
Ao analisar e criticar o filósofo Antonio Gramsci, Eagleton (1991) alega que a ideologia dominante, ou hegemônica, trabalha mais com consentimento do que com coerção e propõe a seguinte questão: “Como combater um poder que se tornou o 'senso comum' de toda uma ordem social [...]?"137 (EAGLETON, 1991, p. 114). Hegemonia, de acordo com Raymond Williams (1977), é a ideologia posta em prática, uma espécie de cultura, pois engloba todo o processo social, de visão de mundo às práticas sociais. De volta a Ham on Rye pode-se ver o produtivo poder invisível da ideologia abarcando o pai do protagonista e interferindo não somente no que ele pensa, mas no que faz, na sua "prática social”. O avô de Henry Junior não encontra as ruas pavimentadas de ouro quando emigra para os EUA, e ainda assim isso não faz com que o pai do protagonista questione o 'sonho americano': “[A] consciência do oprimido é normalmente uma amálgama contraditória de valores embebidos dos governantes com noções que vieram mais diretamente de suas experiências práticas."138 (EAGLETON, 1991, p. 36). Em um momento, quando descontente com o emprego que tem, o pai de Henry Junior fala para o próprio filho:

Você sabia que nos mares do sul os nativos moram em cabanas de capim? Eles se levantam de manhã e a comida cai das árvores no chão. Eles apenas pegam e comem, cocos e abacaxis. E os nativos pensam que os homens brancos são deuses! Eles pescam peixe e assam javalis, e as garotas dançam e vestem saias de capim e esfregam as orelhas dos seus homens. ${ }^{139}$ (BUKOWSKI, 1982, p. 58)

O avô de Henry Junior vem da Alemanha para os EUA acreditando em uma metáfora de oportunidade: as ruas de ouro. E agora o pai de Henry Junior cria a sua própria ilusão de paraíso como forma de projetar a sua frustração com o que a 'América' o oferece. De acordo com o que é analisado nos capítulos anteriores, o 'sonho americano' é ilusório e o pai de Henry o busca obcessivamente, e mesmo quando não há chance alguma, passa a mentir assim como na fala acima, quando inventa um lugar metafórico para compensar a realidade opressora, mas que ao mesmo tempo, a legitima. Ao consentir cegamente com a ideologia dominante, o pai de Henry Junior se encontra preso à sua ambição em ser rico. Longe de querer se conscientizar de sua reificação, o pai do protagonista age e reage hipocritamente, servindo como um sancionador do 'sonho americano', mesmo sem conseguir realizá-lo.

\footnotetext{
137 "How do we combat a power which has become the 'common sense' of a whole social order [...]?"

138 " [T] he consciousness of the oppressed is usually a contradictory amalgam of values imbibed from their rulers, and notions which spring more directly from their practical experience."

139 "Do you know that in the South Seas the natives live in grass shacks? They get up in the morning and the food falls from the trees to the ground. They just pick it up and eat it, coconuts and pineapple. And the natives think that white men are gods! They catch fish and roast boar, and their girls dance and wear grass skirts and rub their men behind the ears."
} 
O 'sonho' é componente da cultura estadunidense que ao longo do tempo obtém características naturais, processo primordial da legitimação ideológica. Quanto a isto, Eagleton (1991, p. 114) pondera: “O que precisa também ser contestado é toda a área da “cultura' [...] O poder da classe dominante é tanto espiritual quanto material"140 o que nos leva a um outro pensador interessado no tema ideologia. O filósofo francês Louis Althusser em Ideologia e aparelhos ideológicos do estado (1970) alega que ideologia é institucional. As empresas capitalistas precisam de força de trabalho para que elas continuem operando e não conseguem por si só reproduzi-la. Esta reprodução, essencial para o Capitalismo, se passa fora da empresa. A necessidade não é apenas numérica, mas também técnica (ALTHUSSER, 1970) e moral, daí o papel da escola como aparato ideológico. A escola ensina não somente técnica, mas também moral e bons costumes e, por conseguinte, a submissão às regras da ordem estabelecida, fundamentais para a perpetuação do Capitalismo. Althusser (1970) cunha então o termo Aparelho Ideológico do Estado, ou AIE.

O Estado, superestrutura do Capitalismo e representante das classes dominantes, detém o monopólio de coerção (EAGLETON, 1991), mas em concordância com Althusser (1970), não se pode governar somente por repressão, faz-se necessário ter a dispor o poder ideológico para que haja a manutenção da hegemonia por meio de consentimento, ou segundo Williams (1977), por meio de autoidentificação. Eagleton (1991, p. 83 e 85) afirma que superestrutura não é algo fixo, ela depende de perspectivas e, assim sendo, pode ser relativizada. Ao tratar a relação de uma instituição ou livro com a ideologia dominante, está se falando de superestrutura. O Capitalismo reificante transfere a ideologia da superestrutura para a base, desumanizando as relações sociais, dando certo caráter estático à sociedade. $\mathrm{O}$ Estado não pode controlar todos os indivíduos de uma sociedade. Portanto, o sujeito deve ser autogovernado, absorver as ideias da classe dominante para que haja continuidade (EAGLETON, 1991) do establishment, para que a sociedade permaneça estática, assim como o pai de Henry Junior o faz. Para Althusser (1970), o indivíduo é interpelado pela ideologia para se tornar sujeito, mas há uma proposital ambiguidade presente nisto que serve ao Capitalismo. A ideologia quer que o indivíduo acredite que ele é um sujeito livre "autor e responsável pelos seus atos” (ALTHUSSER, 1970, p. 113), ao passo que o sujeito na verdade é um indivíduo que se sujeita, portanto, não-livre, entregue à sujeição.

Em Ham on Rye, conforme visto no capítulo anterior, Henry Junior questiona o ensino médio como sendo uma forma de se sujeitar e ter o próprio futuro guiado pelo outros. Não

\footnotetext{
140 "What must also be contested is the whole area of 'culture'[...] The power of the ruling class is spiritual as well as material."
} 
obstante, ele entra na universidade como última tentativa de se enquadrar no sistema, para adiante chegar a seguinte avaliação: "Uma educação universitária poderia destruir um indivíduo para sempre. Livros podiam te fazer suave. Se você os largasse e realmente fosse lá fora, então você precisava saber o que eles nunca te contaram." ${ }^{\text {141 }}$ (BUKOWSKI, 1982, p. 299). Henry Junior, já de posse de algum grau de autoconhecimento e consciência de classe, consegue enxergar e questionar o processo de amolecimento e sujeição pelo qual pessoas passam dentro de uma universidade.

Segundo Althusser (1970), outra estratégia da ideologia capitalista dominante é ter a escola como se ela fosse um meio desprovido de ideologia, gerando uma falsa ideia de imparcialidade. Henry Junior desmascara essa incorreção: “A pouca educação que eu me permiti me fez ainda mais desconfiado. O que eram médicos, advogados, cientistas? Eles eram apenas homens que se permitiram ser privados de sua liberdade para pensar e agir como indivíduos."142 (BUKOWSKI, 1982, p. 307). Assim sendo, há uma contraposição entre indivíduo e liberdade por meio de Henry Junior quando este conclui que um indivíduo que é interpelado pela ideologia por meio de um AIE, neste caso a escola, sujeita-se ao poder dominante em troca de uma ilegítima sensação de individualidade.

Mais ao fim da narrativa, depois de abandonar a universidade, começa a frequentar sarjetas para se socializar com o seu provável futuro, somente para encontrar mais pessoas sujeitas ao sistema: “Aqueles homens e mulheres não tinham nenhuma ousadia especial ou brilho. Eles queriam o que todos os outros queriam."143 (BUKOWSKI, 1982, p. 307). Essa reflexão de Henry Junior evidencia a sua busca por conhecimento como possível saída contra a opressão. Assim como ele sente ser coagido a fazer coisas pelas quais não se interessa, ele igualmente vê essa coerção e consentimento por toda a sociedade. O fato dos pobres quererem o mesmo que os ricos faz com que a personagem perceba novamente uma das facetas da ideologia burguesa, ou seja, o bloqueio da autorreflexão por meio das instituições. Tanto a classe dominante quanto os desprovidos estão reificados e submissos, consentindo então com o que é pregado. E a personagem não é diferente, pois conforme visto, ela se encontra muitas vezes como sendo uma vítima da reificação.

\footnotetext{
141 "A college education could destroy an individual for life. Books could make you soft. When you put them down, and really went out there, then you needed to know what they never told you."

142 "The little education I had allowed myself had made me more suspicious. What were doctors, lawyers, scientists? They were just men who allowed themselves to be deprived of their freedom to think and act as individuals."

143 "Those men and women had no special daring or brilliance. They wanted what everybody else wanted."
} 
Deste modo, em termos ideológicos, concluo que na construção de Henry Junior há o que Lukács ([1955] 2011) chama de conversão psicológica da personagem. O sofrimento que aflige o protagonista por causa de sua classe social não é pretexto, e sim uma das formas de Henry Junior perceber que a ideologia do sistema capitalista é uma das fontes de tal sofrimento, fazendo-o querer se livrar desta situação, frequentemente fazendo-o ir contra as determinações das autoridades, sejam estas representadas pelo seu pai ou pela nação. Os conflitos sociais produzem transformações na consciência do protagonista gerando certa resistência política. Henry Junior resiste politicamente ao poder superestrutural do Estado depois dos conflitos o terem transformado. Com a ajuda da literatura, como veremos a frente, a personagem tenta se livrar das forças ideológicas que constantemente legitimam a sociedade estadunidense como hegemônica; constituem o Capitalismo como única saída; o 'sonho americano' como essencialmente positivo e natural; a guerra como forma de gerar um falso pertencimento; e finalmente, a família como AIE a ser venerado.

\subsection{O realismo de Lukács e a figuração do displaçamento}

Ora classificado como marxista ortodoxo, ora como exageradamente formalista, Lukács e sua obra não são unanimidades nem mesmo para o próprio autor. Os diferentes contextos históricos vividos pelo escritor podem explicar tanto a recepção, como as variações de opiniões da crítica e de Lukács quanto à arte e à sua própria teoria. Veremos que Ham on Rye muitas vezes contesta parte da teoria de Lukács. Contudo, uma vez que os assuntos totalidade e dialética sujeito-objeto constituem conceitos fundamentais para a análise da narrativa, cabe a essa dissertação analisar e utilizar conceitos do livro A teoria do romance (2000) de Lukács.

Em virtude da decadência do mundo antigo e a ascensão da burguesia, o sujeito adquire um caráter problemático ao se deparar com um mundo sem deuses. O trabalho alienado do Capitalismo fragmenta a união do indivíduo com a sociedade, e com isso, o sujeito perde o contato com a totalidade histórica. O mundo moderno supera o mundo primitivo em termos tecnológicos, porém há perdas como, conforme exposto, a totalidade imanente. Devido à fragmentação, a forma épica moderna romance se torna uma totalidade criada e conquista uma característica mais independente da realidade que à da épica grega (LUKÁCS, 2000). O herói do romance tenta reencontrar a totalidade perdida que outrora 
pertenceu aos heróis dos épicos antigos, e essa busca, esse retorno a ela, é impossível na sociedade atual. Porém, é exatamente essa busca irrealizável que caracteriza o herói problemático de Lukács (2000), pois a busca não é irreal e nem necessariamente infrutífera, já que ao longo desta, o herói adquire autoconhecimento: "Depois da conquista desse autoconhecimento, o ideal encontrado irradia-se como sentido vital da imanência da vida, mas [...] só é possível alcançar um máximo de aproximação, uma profunda e intensa iluminação do homem pelo sentido de sua vida.” (LUKÁCS, 2000, p. 82). Nesta busca de autoconhecimento, ou "peregrinação do indivíduo problemático rumo a si mesmo" (LUKÁCS, 2000, p. 82), o herói do romance chega a uma percepção de pertencimento ao gênero humano e consciência de sua própria finitude. Em Ham on Rye, Bukowski retrata a fragmentação da totalidade por meio da personagem Henry Junior entrando em conflito com diferentes aparatos ideológicos dos EUA, conflitos que representam, inicialmente, a coerção do estado, e em parte, o rompimento do protagonista com os valores da sociedade.

Assim como coloca Lukács (2000), a vida perde seu sentido imanente por não haver mais reciprocidade entre o sujeito e o objeto. Henry Junior, pode-se dizer, é um representante típico dessa ausência de equilíbrio entre a nação e o cidadão, ou entre o indivíduo e a coletividade. Tipicidade é a formação de tipos sociais que concentram tendências universais em individualidades singulares (FREDERICO, 2013, p. 49), é o espaço onde o singular se universaliza, e vice-versa, na história individual ou coletiva. O tipo é uma figura social que funciona como elo entre o indivíduo empírico e a sociedade: “[...] é na representação típica, na descoberta de caracteres e situações típicas, que as mais importantes tendências da evolução social conseguem uma expressão artística apropriada.” (LUKÁCS, 2009, p. 106). Já para Raymond Williams (1977), o típico revela elementos permanentes da condição humana. Por conseguinte, se na epopeia grega as tendências da sociedade eram retratadas, no romance as contradições é que são. De acordo com Lukács (2009), a sociedade capitalista provê mais que uma luta de indivíduos dentro do romance, há conflitos com a própria sociedade, e personagens típicas em situações típicas apresentam possibilidades dentro do cotidiano. Assim sendo, conforme visto nos capítulos anteriores da dissertação, o que em sociologia é uma tensão entre privado e público e em psicologia é o conflito entre ego, id e superego, neste capítulo, seguindo a teoria de Lukács, é o homem contra a degradação do homem.

Segundo Lukács (2009), para se chegar ao típico no romance há a necessidade de mediação, que para o crítico Raymond Williams (1977) é um processo ativo de interação entre forças separadas dentro de uma totalidade. Mediações em Ham on Rye aparecem como conflito de classes, nacionalismo, conflito familiar, crise do liberalismo e guerra. Lukács 
trabalha, assim, dialeticamente, em uma linha histórica: se na Grécia Antiga há conflitos externos, no romance moderno há conflitos internos, fruto da fragmentação causada pelo conflito de classes. O (re)encontro, síntese ou reconciliação entre individual e universal evidencia o típico do romance.

O romance como totalidade e a figuração de personagens típicos são elementos formais de um componente caro na crítica literária de Lukács, o realismo: "A representação da ação, ligando a subjetividade humana ao mundo objetivo, é o eixo básico da defesa lukácsiana do realismo, [neste] a criação de caracteres e situações típicas faz com que as grandes contradições do mundo burguês perpassem as personagens." (FREDERICO, 2013, p. 68-69). Realismo, portanto, em termos lukácsianos, não é escola literária, mas sim método de criação, uma tomada de posição perante a realidade: "Para ser realista, o autor não precisa partir de um modelo prévio, mas sim entregar-se ao objeto - a especificidade da vida social que ele pretende retratar.” (FREDERICO, 2013, p. 112). Sendo assim, por meio da sua personagem típica, Henry Junior, Bukowski escreve um romance realista contemporâneo como mimesis do sistema de ideias vigente no entre guerras nos EUA. Ao trabalhar com mimesis, cabe retornar a Aristóteles (Arte Poética, IX) que afirma que a imitação, ou neste caso, a representação, se realiza segundo os meios, os objetos e a maneira. Bem como a história narra os fatos, o escritor narra o porquê dos fatos ocorrerem e as causas dos mesmos. Assim sendo, a obra literária possui um caráter mais filosófico e Bukowski, por meio das mediações em sua narrativa, contrapõe os fatos históricos postos pelos EUA.

Como forma de articular essa representação, o autor de Ham on Rye usa extensamente uma figura de linguagem em sua obra poética e que é analisada por Russel Harrison (1994): a metonímia, um parente da metáfora de Aristóteles (XXI, p. 33), que a classifica como transposição. No tempo presente, há uma separação entre os dois, a metáfora como uma substituição de sentidos e a metonímia sendo uma associação de sentidos (EAGLETON, [1983] 1996) próprios da linguagem humana. Segundo Harrison (1994), na poesia de Bukowski, há uma forte e peculiar presença de metonímia em detrimento da metáfora, caracterizando a recusa do autor em aceitar uma unidade maior que o próprio indivíduo e essa forma de representação é também encontrada na prosa Ham on Rye. Ao fim da narrativa, quando os EUA entram em guerra com o Japão, Henry Junior verifica a conjuntura: “América estava em guerra. Olhei na minha carteira: Eu tinha um dólar. Contei minhas moedas: 67 centavos." ${ }^{144}$ (BUKWOSKI, 1982, p. 315). A nação está para entrar no maior conflito armado

\footnotetext{
144 "America was at war. I looked into my wallet: I had a dollar. I counted my change: 67cents."
} 
da história, mas o indivíduo Henry Junior associa a guerra a sua própria situação de desempregado e sem dinheiro, uma guerra individual mais importante que a guerra da coletividade EUA.

Ainda na narrativa, por muitas vezes Henry Junior descreve metonimicamente outras pessoas, e às vezes a si mesmo, como membros humanos. No capítulo em que a personagem tem a face enfaixada por causa da sua terrível acne, ele se sente bem pela primeira vez em tempos: "Nada podia ser visto a não ser meus olhos, minha boca e minha orelhas [...]."145 (BUKOWSKI, 1982, p. 157). A invisibilidade neste trecho funciona como uma trégua para o protagonista, que se sente temporariamente livre da opressão externa quando não pode ser visto pelos outros. Logo após ter a cara enfaixada, Henry Junior começa a escrever sobre o Barão Von Hilmmen, personagem que no capítulo anterior concluí como sendo uma compensação para desejos reprimidos e repulsa do protagonista a si mesmo. A metonímia está presente na criação de Henry Junior, quando este está somente com os olhos à mostra: "Ele era um homem feio com cicatrizes no rosto, mas ele era bonito se você o olhasse por algum tempo - estava em seus olhos, seu estilo, sua coragem, sua feroz solidão."146 (BUKOWSKI, 1982, p. 159). Além da ficção ser um componente inconsciente de compensação para o displaçamento da personagem Henry Junior, a ficção composta por metonímias por Bukowski também nos dá pistas sobre o método de composição realista do autor.

A metonímia também é utilizada de outras formas por Bukowski ao longo da narrativa. No momento em que alguns garotos da escola tentam provocar Henry Junior atirando propositalmente uma bola de futebol em sua cabeça, ele pensa: "Era como estar em uma gaiola. Eles estavam ao meu redor, faces, narizes, bocas e olhos." ${ }^{147}$ (BUKOWSKI, 1982, p. 29). A metonímia de Bukowski nesta passagem evidencia a redução dos opressores de Henry Junior. Os inquisidores sendo descritos como fragmentos representando a própria fragmentação dos garotos e a violência sem sentido por eles praticada. Sequencialmente à provocação, quando Henry Junior leva a primeira e injusta surra paterna de sua vida, há uma emblemática metonímia: “[...] a violência nele fazia todo o resto desaparecer totalmente. Ele era todo orelhas, nariz, boca, eu não conseguia olhar para os seus olhos [...]."148 (BUKOWSKI, 1982, p. 34). Quando o pai o obriga a parar o futebol americano com os

\footnotetext{
145 "Nothing could be seen but my eyes, my mouth and my ears [...]."

146 "He was an ugly man with scars on his face, but he was beautiful if you looked long enough - it was in the eyes, his style, his courage, his fierce aloneness."

147 "It was like being in a cage. They stood around me, faces, noses, mouths and eyes."

148 " [...] the violence of him made everything else utterly disappear. He was all ears, nose, mouth, I couldn't look at his eyes [...]."
} 
colegas para que ele corte a grama da casa, o protagonista volta a descrever o pai da mesma maneira: "[...] e como eu disse, ele parecia ser todo orelhas, boca e nariz quando estava bravo. Eu não conseguia olhar para os seus olhos." ${ }^{419}$ (BUKOWSKI, 1982, p. 67). Os olhos, símbolos junguianos de consciência e razão, não podem ser vistos no pai da personagem, que se encontra sob efeito da reificação e não consegue acessar sua consciência de classe. Portanto, o pai de Henry Junior sem os olhos é a metonímia da sujeição acrítica à coletividade e da negação da própria individualidade, da entrega cega ao sonho americano e da violência sem sentido. Em Ham on Rye, o indivíduo sem os olhos é o indivíduo não consciente.

Além disso, o pai do protagonista é frequentemente descrito pelo narrador por meio da boca, na maioria das vezes quando a família Chinaski se encontra na mesa de jantar. Os olhos e a boca evidenciam a dialética metonímica do autor entre superficialidade e profundidade, se os olhos são a consciência, a boca é a irracionalidade. Em diversas partes do romance, algumas destas analisadas acima, Henry Junior presta muita atenção nos olhos das pessoas, a parte do corpo mais mencionada na narrativa (BUKOWSKI, 1982), sendo estas pessoas boas ou más. Ele próprio quando consegue se esconder dos outros quando tem a cara enfaixada, tem os seus olhos descobertos, salientando que ele está se isolando da coletividade cega e possui consciência e individualidade, mantendo seus próprios olhos para continuar o processo de observação e entendimento do mundo.

Seguindo a dialética entre superficialidade e profundidade da metonímia comentada por Harrison (1994) presente na poesia de Bukowski, pode-se encontrar esta figura como forma de representação de uma negação dialética da personagem Henry Junior em Ham on Rye. O fato dela não querer mais participar de esportes é um dos exemplos de metonímia da negação dos valores dos EUA. Dentro de casa, o pai de Henry Junior, metonímia da repressão coletiva, critica o filho por ele ouvir sinfonia e não fazer uso disso, por ler literatura e finalmente por querer ser escritor (BUKOWSKI, 1982). O conflito entre o pai, representante da materialidade utilitarista dos EUA, e Henry Junior, representante da arte, é a metonímia do Capitalismo sendo hostil à arte, como atesta Marx (LUKÁCS, 2009), por mim observado em Ham on Rye. Em certo momento, pensando consigo mesmo, Henry Junior volta a avaliar o pai por meio de membros: "Eu olhei para o meu pai, para as suas mãos, sua face, suas sobrancelhas, e eu sabia que esse homem não tinha nada a ver comigo. Ele era um estranho."150 (BUKOWSKI, 1983, p. 214). O sujeito Henry Junior nega ser semelhante ao pai,

\footnotetext{
149 "[...] and like I said, he looked to be all ears, mouth and nose when angry. I couldn't look at his eyes."

150 "I looked at my father, at his hands, his face, his eyebrows, and I knew that this man had nothing to do with me. He was a stranger."
} 
um embate interno que nem sempre produz uma resposta verdadeira, pois a personagem age muitas vezes como o pai e, consequentemente, também como a coletividade, já que o pai se configura em um representante da aceitação da ideologia dominante. Portanto, nem sempre a negação de Henry Junior produz uma antítese.

Essa vontade de Henry Junior de se diferenciar do pai, e, por conseguinte, da coletividade, gera um conflito social, psicológico e dialético na personagem que perpassa os elementos formais de Ham on Rye. Metonímia é um elemento preponderante na poesia de Charles Bukowski presente também em Ham on Rye. Contudo, dialeticamente, dentro da narrativa, não há como substituir sem associar, e vice-versa. À vista disso, têm-se do mesmo modo a metáfora, figura de linguagem presente na narrativa também para descrever pessoas com quem seu herói se relaciona e às vezes consigo mesmo, já investigada nos arquétipos de Jung no capítulo anterior desta dissertação. Em concordância com o que foi analisado, Henry Junior não possui muitos amigos ao longo de sua juventude. Não obstante, mesmo se sentindo constantemente displaçado, a personagem convive com algumas pessoas, mesmo que contra sua vontade (BUKOWSKI, 1982). O primeiro colega da escola que se aproxima de Henry Junior é David, um menino vesgo que veste meias-calças quem a personagem culpa pelo fato dos colegas de escola não o quererem nos times de esporte. Na rua onde mora, aparece Red, o garoto sem um braço com quem Henry Junior tem a sua primeira prática de futebol americano. Já no colégio, é a vez de Baldy, um menino careca, se aproximar de Henry. Em sua única experiência de emprego como estoquista, ele começa a descrever os colegas: o chefe não tem uma orelha, há um corcunda, um homem que parece com pretzel e há um albino caolho (BUKOWSKI, 1982). Ao se indagar sobre a sua situação displaçada em certo momento no colégio, Henry Junior conclui:

Reunidos ao meu redor estavam os fracos ao invés dos fortes, os feios em vez dos bonitos, os perdedores ao invés dos vencedores. Parecia que era meu destino viajar em companhia deles pela vida. Isso não me incomodava tanto quanto o fato de que eu parecia irresistível para esses idiotas estúpidos. Eu era um cocô que atraía moscas ao invés de uma flor que borboletas e abelhas desejavam. Eu queria viver sozinho, eu me sentia melhor sozinho, mais limpo, porém eu não era esperto o suficiente para me livrar deles. Talvez eles fossem meus mestres. Pais em uma outra forma. ${ }^{151}$ (BUKOWSKI, 1983, p. 169)

\footnotetext{
151 "Gathered around me were the weak instead of the strong, the ugly instead of the beautiful, the losers instead of the winners. It looked like it was my destiny to travel in their company through life. That didn't bother me so much as the fact that I seemed irresistible to these dull idiot fellows. I was like a turd that drew flies instead of like a flower that butterflies and bees desired. I wanted to live alone, I felt best being alone, cleaner, yet I was not clever enough to rid myself of them. Maybe they were my masters: fathers in another form."
} 
Isso tudo em comparação aos outros meninos ricos da escola e aos vendedores da loja onde trabalha, frequentemente descritos de forma aparentemente positiva. Como forma de recusar ser como os fracos que buscam a sua presença, Henry Junior projeta as suas falhas ao descrever os outros, comportamento semelhante ao do pai. Essa atitude, de alta carga ideológica, é uma constatação da característica problemática do herói Henry Junior, que mesmo encontrando conhecimento na busca por emancipação, age como os seus pares reificados. Ao responsabilizar o externo pelas suas imperfeições, Henry Junior demonstra ser tão frágil à sujeição quanto os indivíduos que convive e critica.

Outro elemento formal encontrado em Ham on Rye que nos possibilita analisar o encontro sujeito-objeto é o fluxo de consciência. Henry Junior vive a dialogar consigo mesmo, fazendo com que somente os leitores do romance percebam contradições entre o discurso e as atitudes do protagonista, ou entre consciência e prática social. Ao ir à praia com o seu colega Jim, ele sente vergonha de seu corpo cheio de espinhas e também inveja das pessoas ao redor:

Tentei fazer o Jim pegar um lugar na praia onde não tivessem muitas pessoas. Eu me sentia normal ali com a minha camisa, mas quando me despia eu estava exposto. Eu odiava os outros banhistas com seus corpos intocados. Eu odiava todas as malditas pessoas que estavam tomando sol, ou na água, ou comendo, ou dormindo, ou falando, ou jogando vôlei de praia. Eu odiava suas costas e suas faces e seus cotovelos e seus cabelos e seus olhos e seus umbigos e seus trajes de banho. ${ }^{152}$ (BUKOWSKI, 1983, p. 181)

Desta vez, insatisfeito com a própria situação, Henry Junior projeta o seu descontentamento em pessoas descritas positivamente como forma de culpá-las pelos seus defeitos, assim, novamente, como o pai. Portanto, ora os deformados como ele são culpados por seu displaçamento, ora as pessoas sem problema algum também o são.

Henry Junior quer demonstrar valentia e muitas vezes o faz. Mas em outras ele apenas finge ser valente, uma falsidade covarde característica de seu pai. Ademais, Henry Junior manifesta indiferença com as garotas em sua atitude, mas no fundo pensa nelas e as quer: "As garotas estavam impossivelmente fora do meu alcance e então eu fingia que elas não existiam."153 (BUKWOSKI, 1982, p. 175). Ou na ocasião em que, conforme comentado, ele quer se esconder da civilização levando mantimentos produzidos por ela. Essa contradição

\footnotetext{
152 "I tried to get Jim to pick a spot on the beach where there weren't too many people. I felt normal standing there in my shirt but when I undressed I was exposed. I hated the other bathers for their unmarred bodies. I hated all the god-damned people who were sunbathing or in the water or eating or sleeping or talking or throwing beachballs. I hated their behinds and their faces and their elbows and their hair and their eyes and their bellybuttons and their bathing suits."

153 "The girls were impossibly out of reach for me and so I pretended that they didn't exist."
} 
performática explicitada pelo fluxo de consciência é mais uma metonímia de Bukwoski como forma de usar a sua personagem como representação das contradições da sociedade mercantil estadunidense e os efeitos delas no indivíduo. As contradições internas do herói do romance adquirem um caráter reflexivo da realidade concreta, ou seja, o sujeito à mercê da marginalização social e dos efeitos do Capitalismo há de entrar em conflito não somente contra a coletividade, mas também consigo mesmo.

Do mesmo modo que os arquétipos de Jung no capítulo anterior da dissertação são forma e precisam de experiências individuais para se tornar conteúdo, a forma romanesca tem significado quando a realidade nela se revela. A forma precisa da realidade para existir. A obra literária é um mundo em si, mas não nega o mundo exterior (LUKÁCS, 2000). A realidade entra na obra e se torna forma. Desse modo, a metonímia e a metáfora como figuras de linguagem na composição de Ham on Rye são parte da forma, que, tornam-se conteúdo uma vez em contato com a realidade:

Esse entrecruzamento entre os destinos individuais e as possibilidades concretas postas pelo desenvolvimento social é a chave do romance realista. Se o homem é um ser social, a verdade do indivíduo é a verdade das possibilidades postas pelo próprio desenvolvimento da realidade social. (FREDERICO, 2013, p. 109)

À vista disso, têm-se um encontro entre arte e realidade. O realismo lukácsiano presente em Ham on Rye possibilita ao leitor perceber as contradições da sociedade estadunidense por meio da universalização dos conflitos individuais de Henry Junior. Contudo, o que fazer com tal percepção? Pode a criação utópica artística se converter em ações? Bukowski responde sim a essa pergunta. Há ações providas e motivadas pela arte. A arte, conforme visto, é uma fonte de esperança para o protagonista, e este de posse de tal, aceita o seu destino como pária social, não se importa em ser desempregado e tampouco quer participar da guerra. Essa indiferença é uma forma de ativismo contra os preceitos do Capitalismo e contra a comunidade imaginada dos EUA se mobilizando para a guerra.

Assim sendo, Henry Junior não é um indivíduo contemplativo como personagens do Romantismo do século XIX que Lukács tanto critica. Inclusive, corroborando a crítica de Lukács, Henry Junior, já decidido a ser escritor, conversa com seu único amigo Becker sobre as revistas estadunidenses que publicam literatura: "Isso aqui é 1940. Eles ainda estão publicando coisas do século passado, pesadas, elaboradas, pretensiosas. Você ou fica com dor 
de cabeça lendo ou cai no sono."154 (BUKOWSKI, 1982, p. 288). Esta postura da personagem denota uma posição crítica quanto à sociedade da época e à literatura produzida por esta. Se a arte é reflexo da realidade, então a arte do entre guerras é o reflexo do que a sociedade representa para Henry Junior: pretensiosa e reacionária.

No decurso de sua juventude, o protagonista de Ham on Rye, na sua busca de autoconhecimento, está a lapidar-se, em um "processo educativo", característica do que Lukács (2000) chama de romance de educação, remetendo a outro termo da crítica literária, o romance de formação. Henry Junior quer intervir no mundo e as maneiras que encontra são a desobediência civil, fixidez frente ao movimento da coletividade, consumo de literatura e posteriormente a produção de sua própria arte, esta se apresenta como uma forma de Henry Junior realizar a sua interioridade no externo, uma forma de agir no mundo, questionando as limitações impostas pela história, tornando-se um homem de ação de Nietzsche (2015).

Ao falar de homem de ação e retomando Cresswell (2006), estamos de novo de frente a uma resistência de Henry Junior por meio da fixidez. Lukács (2000) afirma que a incongruência entre interioridade e o mundo convencional leva à negação do mundo. Porém, a negação do mundo da personagem retorna ao mundo exterior como uma maneira de Henry Junior questionar a realidade em que vive, especialmente quando ele passa a ler e seguidamente escrever, levando-o ao autoconhecimento. O mesmo processo que pode acontecer com quaisquer leitores de um romance realista não é um processo tão idealista quanto Lukács prega para Bukowski: a sua personagem percebe, de fato, as contradições do Capitalismo e obtém conhecimento por meio da arte a ponto de querer ser um artista e lutar contra convenções da coletividade. Porém, o processo não se dá por encerrado na narrativa, pois Henry, apesar de tudo, é também uma vítima dos preceitos de comunidades imaginadas e da família, e, por muitas vezes, conforme analisado, comporta-se de uma maneira que a ideologia dominante apreciaria, ora sendo um bully, ora querendo possuir bens materiais. Portanto, há a busca por autoconhecimento por parte do protagonista e ela é positiva, mas a “intensa iluminação" pretendida por Lukács não necessariamente acontece com Henry Junior.

Às vezes com elementos de romance de desilusão, ora com de romance de formação, outras com configurações de romance de educação, com um herói problemático de atitudes difusas, que se utiliza da passividade como ação, Ham on Rye é um exemplo contemporâneo de uma obra realista com alguns moldes lukácsianos e com algumas críticas à estes que

\footnotetext{
154 "This is 1940. They're still publishing 19th Century stuff, heavy, labored, pretentious. You either get a headache reading the stuff or you fall asleep."
} 
merecem uma abordagem mais profunda sobre a sua forma, em outra interpelação preponderante por meio da obra de György Lukács: o romance histórico.

\subsection{A história em Ham on Rye}

Dentro de Ham on Rye, há a presença decisiva de fatos históricos que influenciam e se entrelaçam com a vida da personagem fictícia Henry Junior. Ao considerar uma obra literária como ficção histórica, ou como romance histórico do ponto de vista de Lukács, faz-se necessário retomar algumas de suas alegações sobre tal categoria do gênero romance e, ao mesmo tempo, não separá-la do grande gênero narrativo. Ainda, também é preciso contextualizações históricas não somente do período retratado pelo romance, mas também do período em que foi escrito, pois a importância que é dada ao processo histórico no entrelaçamento entre obra de arte e realidade por Lukács nos motiva a esse tipo de abordagem. Ademais, pelo fato de Charles Bukowski por meio de Henry Junior nem sempre concordar com Lukács, faz-se necessário a aplicação de outros teóricos interessados na relação entre história e arte que também por vezes discordam ou complementam a teoria lukácsiana. Por fim, cabe-nos a pergunta: qual seria a intenção de Charles Bukowski em escrever um romance histórico na década de 1980 ?

O que é preponderante na obra de Lukács e para esse capítulo é a concepção da totalidade do processo histórico e seus desdobramentos, tanto na vida concreta, quanto na obra de arte. Para a estudiosa de Lukács, Arlenice Almeida da Silva (2011, p. 10), na introdução de $O$ romance histórico, "a questão da totalidade impõe-se como pressuposto da análise" de uma obra. A “totalidade histórica em devir", proposta por Lukács, nos leva ao conceito de passado não divorciado do presente. Ao falar do passado, o romance histórico está na verdade fazendo uma reflexão sobre o presente, ou como diz a professora estudiosa de Lukács, Regina Zilberman (2003, p. 130) o romance histórico “[p]ode ajudar a entender a atualidade, mas na perspectiva da formação da sociedade que conhecemos no presente." Desta forma, há uma figuração do passado para explicar o presente (LUKÁCS, [1955] 2011) fazendo com que o passado esteja no presente e influencie o futuro. No romance histórico de Lukács, assim como na vida concreta, o presente deve ser compreendido como história em movimento contrapondo uma noção de sociedade estática. Se há movimento, há possibilidade de mudança. 
A maneira histórico-dialética lukácsiana de enxergar a evolução humana nos permite entender melhor a intercalação dos processos envolvidos em cada momento histórico. Tal articulação, segundo o filósofo húngaro, é uma forma de se adquirir consciência que leva o indivíduo a problematizar as mudanças que ocorrem na história, conectando-as ao passado (LUKÁCS, [1955] 2011), fazendo-o entender o presente, e ulteriormente, buscar um futuro diferente. A "história como processo" e "história como precondição do presente" (LUKÁCS, [1955] 2011, p. 36) são alguns dos conceitos chave que permeiam o livro $O$ romance histórico e nos ajudam na análise de Ham on Rye, possibilitando-nos o entendimento das "grandes convulsões históricas" presentes na narrativa tais como a crise de 29 e a eclosão da II Grande Guerra. Ao mesmo tempo, transpondo tais entendimentos para a realidade objetiva, configurando assim o entre guerras nos EUA como pré-história do tempo presente da escrita do romance, há de se chegar à conclusão de que Bukowski, escrevendo sobre os anos 30, está também fazendo um comentário sobre os anos 80 .

Se Henry Junior é uma criança-herói usando a teoria de Jung, e se na seção anterior desta dissertação ele é o herói problemático do romance realista de Lukács, aqui, analiso o protagonista pelas características do que Lukács em $O$ romance histórico chama de herói mediano. Em Ham on Rye, o herói mediano é o pobre imigrante alemão Henry Junior, um ator histórico que, ao conquistar certa consciência histórico-social, evidencia as disputas de poder, problematizando a iniquidade da busca do 'sonho americano' e a ininterrupta legitimação ideológica das classes dominantes. Lukács ([1955] 2011, p. 161) caracteriza este tipo de personagem da seguinte forma:

O que qualifica essas figuras a ocupar o centro composicional dos romances históricos são justamente aqueles traços sociais e humanos que banem tais figuras ou fazem-nas desempenhar um papel subordinado e episódico. Pois a falta de clareza dos contornos de seu caráter, a ausência de grandes paixões que conduzam a tomadas de posição resolutas e unilaterais, o contato com os dois campos inimigos em luta etc., tudo isso torna essas personagens aptas a expressar adequadamente, em seu próprio destino, a complexa capilaridade dos acontecimentos romanceados.

Cabe aqui complementar a definição de herói mediano com uma análise de uma famosa discípula de Lukács, Agnes Heller (1991). Para a estudiosa, além da definição do filósofo húngaro para o herói mediano ser um tanto quanto vaga, o herói mediano não necessariamente é medíocre. Para Heller (1991), o fato de ele ser 'mediano' denota sua função de 'mediar' conflitos históricos representativos. A percepção relativamente ampliada dada a Henry Junior por Charles Bukowski, portanto, é um dos atributos do herói mediano de Lukács. A personagem é um indivíduo aparentemente comum e como forma de construção de 
um romance histórico, Charles Bukowski aumenta a percepção das transformações sociais nela: "O destino que cabe ao herói mediano, que na grande crise de seu tempo não se alia a nenhuma das partes em conflito, pode fornecer [...] esse elo" (LUKÁCS, [1955] 2011a, p. 53) entre os dois lados do conflito. Conforme analisado, Henry Junior questiona e não compactua com a ideologia capitalista estadunidense, tampouco se alia aos nazistas, estabelecendo-se, portanto, como ligação entre as duas forças históricas que se digladiam naquele momento.

A consciência alcançada por Henry Junior nos remete ao "anacronismo necessário" de Lukács quando analisa o romance histórico de Walter Scott. Do mesmo modo que a Revolução Francesa é "essa convulsão do ser e da consciência dos homens em toda a Europa [que] formam as bases econômicas e ideológicas para o surgimento do romance histórico de Walter Scott” (LUKÁCS, [1955] 2011, p. 47), a crise do liberalismo econômico dos anos 1980 engendra as bases ideológicas do romance histórico sobre os anos 1930 de Charles Bukowski. Assim como o escritor escocês faz, Bukowski confere à personagem Henry Junior "uma expressão nítida de sentimentos e pensamentos sobre contextos históricos reais" (LUKÁCS, [1955] 2011, p. 84) que um adolescente dos anos 1930 não pode alcançar. O plano público, representado pela nação em guerra e a sociedade em crise, invade o privado, representado no romance pela personagem Henry Junior, um herói que busca o seu caminho, um indivíduo que sai do extrato médio da sociedade e que se vê constantemente tragado pelo sistema, tendo então que tomar partido e agir.

Por ser um romance que se utiliza da história, Ham on Rye apresenta crises históricas factuais em sua composição. As crises históricas são momentos decisivos da narrativa em que o herói mediano Henry Junior incorpora a história (LUKÁCS, [1955] 2011). Assim como afirma Lukács (2011 [1955], p. 91): “[A] história é muito mais que roupagem e decoração; é ela que determina de fato a vida, o pensamento, o modo de sentir e agir das personagens." Ao analisar Hitler, Henry Junior pondera: "Hitler era apenas outro ditador para mim, só que em vez de me repreender na mesa de jantar, ele provavelmente estouraria meus miolos ou minhas bolas se eu fosse à guerra tentar pará-lo." ${ }^{155}$ (BUKOWSKI, 1982, p. 262). Em certo momento, um pouco antes dos EUA entrarem na guerra, Henry Junior examina o então presidente estadunidense Franklin D. Roosevelt:

Eu gostava de Franky por causa de seus programas para os pobres durante a Depressão. Ele tinha estilo também. Eu não achava que ele dava a mínima para os pobres, mas ele era um grande ator, grande voz, e ele tinha um ótimo escritor de discursos. Mas ele nos queria na guerra. Isso o colocaria nos

\footnotetext{
155 "Hitler was just another dictator to me, only instead of lecturing me at the dinner table he'd probably blow my brains out or my balls off if I went to war to stop him."
} 
livros de história. Presidentes de Guerra tinham mais poder e, mais tarde, mais páginas [...] Pobre Franky não tinha pernas, mas ele tinha um cérebro maravilhoso. Em algum outro país ele teria sido um ditador poderoso. ${ }^{156}$ (BUKOWKSI, 1982, p. 298)

Hitler e Roosevelt, quando aparecem em Ham on Rye, são "marionetes ridículas e prejudiciais" (LUKÁCS, [1955] 2011a) da história do ponto de vista de Henry Junior. Hitler, um dos maiores e mais cruéis ditadores do mundo, é equiparado ao pai perdedor, por este ser um símbolo de repressão para o protagonista. Já Franklin D. Roosevelt, um presidente mítico na história dos EUA, considerado por muitos um herói durante a Grande Depressão e a II Grande Guerra, dentro de Ham on Rye é uma figura histórica egoísta, desligada da experiência das massas e que surge "a partir do ser da época, jamais explicando a época." (LUKÁCS, [1955] 2011a, p. 56). Ainda de acordo com Lukács ([1955] 2011, p. 62), “o que importa para o romance histórico é evidenciar, por meios ficcionais, a existência, o serprecisamente-assim das circunstâncias e das personagens históricas.” Após o crash de 29, a maior crise do liberalismo até então (HOBSBAWN, 1995), partidos comunistas e de ultradireita se espalham na Europa e há a necessidade de um líder na maior nação capitalista que combata o 'perigo vermelho' ao mesmo tempo em que faça frente ao avanço do fascismo europeu. Portanto, de acordo com Lukács, e conforme se comprova na ficção de Bukowski, o contexto histórico é que determina a existência de Hitler e Franklin D. Roosevelt, sendo que, caso este, segundo as palavras de Henry Junior, nascesse em outra época e local, não seria um presidente de uma democracia liberal, mas um ditador. E ambos parecem estar mais interessados em imprimirem os próprios nomes nos livros de história ao invés de se preocuparem com justiça ou a sociedade. Dadas às circunstâncias, a esfera privada novamente sobrepõe a esfera pública. Assim como o pai de Henry Junior se preocupa mais com seu jardim do que com a comunidade, os líderes dos países em guerra se preocupam mais com o status que com o bem-estar da população.

Esta visão ampliada de Henry Junior faz com que ele funcione como um ponto de conexão entre o liberalismo estadunidense, na qualidade de grande causador da Grande Depressão, e o fenômeno parecido que ocorre em meados dos anos 80, momento em que acontece outra grande crise do Capitalismo. A crise de 29 é a pré-história da crise dos anos 80

\footnotetext{
156 "I liked Franky because of his programs for the poor during the Depression. He had style too. I didn't think he really gave a damn about the poor but he was a great actor, great voice, and he had a great speech writer. But he wanted us in the war. It would put him into the history books. War presidents got more power and, later, more pages [...] Poor Franky didn't have any legs but he had a wonderful brain. In some other country he would have made a powerful dictator."
} 
denotando a característica cíclica da história e, principalmente, do Capitalismo. De acordo com o historiador Eric Hobsbawm (1995) o Fordismo que acelera a economia dos EUA no início do século XX é um modelo que é ampliado para conjuntos habitacionais e redes de fast food nos anos pós-guerra. Juntando-se este cenário com o contínuo avanço tecnológico, o que se tem nos EUA é um aumento do consumismo. A crise de 29, que quase põe em cheque a existência do Capitalismo, serve como forma de reestruturá-lo, transformando cada vez mais os bens de consumo, inclusive outrora de luxo, em itens necessários, isso só sendo possível pela "democratização do mercado" e pela política de pleno emprego do início do século e agora no pós-guerra. Porém, quando os anos 1980 se veem face a face com uma eminente crise econômica de grandes proporções, há, segundo Hobsbawm (1995) um não reconhecimento do problema pelo fato do termo 'depressão' ter se tornado uma tabu no ocidente. O sistema capitalista, portanto, manipula mais uma vez os dados empíricos como forma de legitimação ideológica.

Novamente, uma crise econômica faz com que a distância entre ricos e pobres aumente. Os mendigos dos anos 80 presentes nas ruas descritas por Hobsbawm (1995) se assemelham às representações literárias de 50 anos antes que aparecem nas praças e sarjetas de Ham on Rye que Henry Junior visita para vislumbrar seu possível futuro (BUKOWSKI, 1982). Apesar de tanto desemprego e pobreza durante a Grande Depressão, Henry Junior percebe a existência no colégio e posteriormente na universidade de vários estudantes ricos com uma vida abastada e consumista. No capítulo da narrativa analisado anteriormente, em que Henry Junior se indaga sobre suas chances na sociedade estadunidense, ele reflete: "Os jovens ricos sentem o fedor dos pobres e aprendem a achá-lo um pouco divertido. Eles têm que rir, senão seria aterrador. Eles aprenderam aquilo com o passar dos séculos."157 (BUKOWSKI, 1982, p. 214). E não obstante, os próprios pobres, inclusive Henry Junior, compactuam com a situação. Seu pai, que lutou na I Guerra, busca o 'sonho americano' e acredita na estrutura familiar, ambos componentes ideológicos do Capitalismo estadunidense. Henry Junior, contudo, enxerga o consentimento e a ganância cega do pai como historicamente cíclicos, e que não permitem o entendimento da realidade:

Olhando para o meu pai eu via nada além de uma estupidez indecente. Pior, ele tinha mais medo de falhar que os outros. Séculos de sangue camponês e treinamento camponês. A linhagem dos Chinaski tinha sido diluída por uma

\footnotetext{
157 "The young rich smell the stink of the poor and learn to find it a bit amusing. They had to laugh, otherwise it would be too terrifying. They'd learned that, through the centuries."
} 
série de serviçais camponeses que tinham rendido suas verdadeiras vidas por ganhos parciais e ilusórios. ${ }^{158}$ (BUKOWSKI, 1983, p. 214)

Em Ham on Rye verifica-se o que Lukács (2011) classifica como conteúdos psicológicos que se entrelaçam com o destino da nação estadunidense e de seu povo. Henry Junior percebe a história se repetindo por meio do conflito de classes exposto pela crise do Capitalismo. Apesar de crises mundiais, os donos do capital continuam a viver abastadamente e até a se divertir com a existência dos pobres enquanto os governantes planejam entrar em guerra para benefício próprio. E o pai de Henry Junior é a metonímia representando os indivíduos das classes mais baixas que consentem e se sujeitam constantemente ao longo da história aos preceitos impostos pela ideologia dominante.

Ressalto novamente que o romance histórico lukácsiano se trata do destino do povo e de como crises afetam a vida privada. Aplicando isto à Ham on Rye, observa-se como a crise de 29 e a Grande Depressão transformam o exterior da vida e alteram o comportamento sócio moral da sociedade estadunidense. Ham on Rye "se desenrola no nível do povo" (LUKÁCS, 2011, p. 345) e possui um herói do povo, um povo que está cego pela mesquinhez capitalista, ganância, racismo e egoísmo. Portanto, apesar do alto teor psicológico presente no romance, os conflitos vividos por Henry Junior podem e devem ser apropriados pelos leitores como fonte de reflexão e como possibilidade de se atingir um senso político mais crítico.

De acordo com a exposição de Hobsbawm (1995), a Grande Depressão fortaleceu o comunismo e criou as bases para o fascismo imperar, para a posterior eclosão da II Grande Guerra. A burguesia passa a se preocupar sobre como os comunistas caracterizam a Crise de 29: “[A] agonia final do sistema capitalista [...].” (HOBSBAWM, 1995, p. 139). Esse choque está presente em Ham on Rye, na reunião do partido nazista que Henry Junior frequenta, os líderes do partido classificam os negros e comunistas como principais ameaças aos EUA (BUKOWSKI, 1982). O romance histórico lukácsiano não trata do conflito histórico unilateralmente. Há de se mostrar os diferentes atores e seus embates, configurando e evidenciando o conflito de classe: “A preocupação com a história serve para desvelar [...] enganos, a fim de evitá-los no futuro.” (LUKÁCS, [1955] 2011, p. 99). Henry Junior, ao compreender o tempo presente como história em movimento, concebe a guerra como apenas uma violenta e inútil expressão do conflito de classes:

\footnotetext{
158 "Looking at my father I saw nothing but indecent dullness. Worse, he was even more afraid to fail than most others. Centuries of peasant blood and peasant training. The Chinaski bloodline had been thinned by a series of peasant-servants who had surrendered their real lives for fractional and illusionary gains."
} 
A guerra. Aqui estava eu virgem. Você pode imaginar ser explodido em prol da história antes de saber o que era uma mulher? Ou possuir um automóvel? $\mathrm{O}$ que eu estaria protegendo? Outra pessoa. Outra pessoa que não dava a mínima pra mim. Morrer em guerra nunca fez com que guerras parassem de acontecer. ${ }^{159}$ (BUKOWSKI, 1982, p. 296)

Lukács descreve bem como que Henry Junior se posiciona sobre a guerra: “As guerras são travadas em nome dos interesses dos exploradores - e nelas as massas exploradas derramam seu sangue.” (LUKÁCS, [1955] 2011, p. 255). Configurando a II Guerra Mundial como uma crise histórica que se repete em benefício de poucos ricos, ou "outra pessoa", nas palavras de Henry Junior, o protagonista incorpora a história, demonstrando uma praticidade no pensamento, uma das características de um herói mediano lukácsiano. Em concordância com o que foi analisado, os EUA no romance são um lugar onde há intensa discriminação e desigualdade, mas em um momento fundamental em que a nação precisa da união dos cidadãos, há uma investida ideológica para que todos incorporem os valores da comunidade imaginada e lutem por ela. De fato, foi assim nas guerras napoleônicas na Europa e é assim na II Guerra Mundial, tanto na Europa quanto nos EUA. Na narrativa, essa estratégia de falsa inclusão é percebida mais de uma vez por Henry Junior, e a sua maneira de agir é a fixidez. A forma que ele encontra de ser um agente da história é transgredindo o movimento que predomina na sociedade:

Eu não era interessado em história mundial, somente na minha. Que bosta. Seus pais controlavam seu período de crescimento, mijam em você todo. Então quando você ficava pronto para ir por você mesmo, os outros queriam colocar você em um uniforme para que atirassem na sua bunda. ${ }^{160}$ (BUKOWSKI, 1982, p. 296)

Vê-se aqui a ideia de que a história é manipulada para justificar a moral vigente (NIETZSCHE, 2015). A moral vigente é a moral capitalista disfarçada de ideais democráticos. Se o fascismo europeu é uma manifestação de reação à crise do liberalismo, os EUA entram na guerra com o intuito de perpetuar a sua hegemonia liberal-capitalista. Portanto, Henry Junior é um sujeito que se conscientiza, primeiramente em contato com a família, um microcosmo repressor que serve aos preceitos da comunidade imaginada nacional, para depois ser doutrinado pela escola, aparato ideológico do Capitalismo que prega

\footnotetext{
159 “The war. Here I was a virgin. Could you imagine getting your ass blown off for the sake of history before you even knew what a woman was? Or owned an automobile? What would I be protecting? Somebody else. Somebody else who didn't give a shit about me. Dying in a war never stopped wars from happening."

160 "I wasn't interested in world history, only my own. What crap. Your parents controlled your growing-up period, they pissed all over you. Then when you got ready to go out on your own, the others wanted to stick you into a uniform so you could get your ass shot off."
} 
o nacionalismo como forma de convencer os indivíduos a participarem da guerra em prol da nação. Ao adquirir relativo livre-arbítrio que o faz considerar-se um indivíduo com direito a escolhas, a participação da Henry Junior na escrita da história pode ser descrita como resistência ao movimento socialmente construído pela coletiviadde.

O herói de Ham on Rye não toma partido a princípio frente à convulsão histórica, para ser gradualmente moldado: "[A] experiência de massa cria possibilidades concretas para que os homens apreendam sua própria existência como algo historicamente condicionado, vejam na história algo que determina profundamente sua existência cotidiana" (LUKÁCS, [1955] 2011, p. 40) e é isso que Henry Junior faz frente a conflitos históricos da proporção da Grande Depressão e da II Guerra Mundial, momentos axiais despertam a consciência histórica da personagem para que ela chegue à conclusão de que, conforme Nietzsche (2015), a história nunca é isenta de valor. Os destinos humanos, assim como o passado e a história, não são decoração, estão interligados com destinos individuais e vice-versa e o pathos de Henry Junior é o entendimento do presente como continuação do passado e de sua negação da história escrita arbitrariamente como forma de participação inautêntica no processo histórico. Se os governantes querem guerra para serem inclusos na história e se a coletividade consente com este movimento, Henry Junior quer uma história da qual somente ele detenha o valor, ou que ao menos detenha um valor autêntico.

A intenção de Bukowski ao escrever um romance histórico, parece-me, é confrontar a história oficial, ou o modo que ela é escrita, por meio de seu herói mediano. É possível, então, classificarmos o autor sob o ponto de vista de Lukács:

[E]le leva seus heróis medianos para o centro da crise histórica, dos grandes conflitos humanos, sobrecarregando-os com provas e missões extraordinárias a fim de, nessas situações extremas, retratar o sobrepujamento de sua mediocridade passada, levá-los à visão daquilo que é humanamente autêntico e verdadeiro, do caráter humanamente autêntico do povo. (LUKÁCS, [1955] 2011, p. 95)

O sofrimento de Henry Junior é o ponto de partida da visão de mundo que Bukowski representa em sua obra. A personagem, ao ser massacrada pela vida cotidiana, absorve a história ao mesmo tempo em que tenta compreendê-la, e por fim, nega-a. Ao questionar a história mundial que o quer como agente somente quando é conveniente para a nação, ou seja, um agente falso, uma marionete, ele se torna um desobediente recusando o nacionalismo cego perante a lógica capitalista. Ao enxergar as contradições históricas do Capitalismo, ao negar o movimento em direção à guerra e ao questionar os aparatos ideológicos a serviço da nação, Henry Junior se torna um homem de ação de Nietzsche, ou um genuíno agente da história. 
Segundo Lukács ([1955] 2011), em um romance histórico, as relações sociais são mais importantes que a autenticidade arqueológica, ou seja, dos fatos históricos per se ali presentes. O leitor de Ham on Rye não encontra na narrativa uma tradução fiel episódica ou "um simples retrato histórico dos costumes" (LUKÁCS, [1955] 2011, p. 106) da época do entre guerras nos EUA, mas sim uma possibilidade de descoberta das mediações geradas pelos conflitos de classe e também de percepção de determinações que podem ajudá-lo a desvendar a origem e as facetas de uma elite burguesa preconceituosa e determinista que prega o "sonho americano'. Essa elite transforma o 'sonho' em um pesadelo para o cidadão médio; vende o igualitarismo, mas impede a impossibilidade de ascensão social; e discrimina minorias por causa de origem, mesmo os EUA tendo um passado construído com base em imigração.

Bukowski trata de brancos rejeitados, um assunto que não interessa aos 'escritores oficiais' da história do entre guerras nos EUA, que é então recontada por meio de Henry Junior. O protagonista, um imigrante alemão pobre é o estranho, ou classificado como tal, que questiona o presente (CHAMBERS, 1994). Segundo Iain Chambers (1994, p. 6): “[O] estranho é perpetuamente requisitado a se sentir à vontade em uma interminável discussão entre uma herança histórica espalhada e um presente heterogêneo." ${ }^{\text {161 }}$ Portanto, a personagem serve como ponto de conexão entre a histeria contra os descendentes germânicos e outras histerias que viriam a seguir, como contra comunistas durante a Guerra Fria ou contra árabes, mais recentemente. Esta consciência aguçada, tanto do autor quanto do protagonista, faz o leitor(a) problematizar o sentido histórico, que para Nietzsche (2015, p. 148) é uma "hierarquia de julgamentos de valor segundo a qual uma nação, uma sociedade, um homem viveram”, uma exagerada busca de detalhes históricos e, novamente, não isenta de valor.

A história, para Nietzsche (2015), pode ser importante se servir para nos fazer agir. O exagero em se estudar e buscar a história preocupa o filósofo alemão, para quem afirma que o excesso de história gera apatia e passividade no indivíduo e no povo. O homem de ação de Nietzsche é um sujeito a-histórico, absorvido pelo presente, sincero e que ama o próprio ato: "[A] resignação lhe repugna, e ele utiliza a história como um remédio contra esta resignação." (NIETZSCHE, 2015, p. 57). Por isso, a história não é um passatempo, tampouco um modelo de vida para Henry Junior, mas um caminho para fazê-lo entender o presente das coisas e buscar um futuro diferente do que querem os seus pares.

Ao negar o passado como modelo para o presente (NIETZSCHE, 2015) ou um futuro vindouro naturalmente mais feliz, Henry Junior transfigura a história clássica. Não quer se

\footnotetext{
161 "[T] $[\mathrm{he}$ stranger is perpetually required to make herself at home in an interminable discussion between a scattered historical inheritance and a heterogeneous present."
} 
prender a um passado grandioso ficcional, bastante utilizado pelo nacionalismo, tampouco a um devir glorioso, articulado pelos discursos do pai, do diretor da escola e pela guerra iminente contra o fascismo. Nietzsche (2015) afirma que estando infeliz consigo mesmo e, portanto, preso a uma veneração ao passado, o presente não produz o que necessita para mudar. Henry Junior como homem de ação não encontra felicidade no passado, nem sabedoria, pois ele descobre que não há onde encontrar felicidade. E o futuro pode ser construído se a personagem não se subordinar à história posta ou resistir à convenção e ao movimento coletivo.

Apesar de nem sempre concordarem um com o outro, Nietzsche e Lukács possuem uma visão afinada sobre a história: o passado pode e deve ser um instrumento de transformação do presente e do futuro. Sem a veia marxista revolucionária e de certa forma idealista de Lukács, Henry Junior é uma personagem com algumas características do herói mediano do romance histórico do autor húngaro, pois nele se encontra a compreensão de que as mudanças que ocorrem na história levam a um possível entendimento sobre as crises do presente. Concomitantemente, há de se ver Henry Junior negando a história mundial, querendo saber somente da sua própria: "Cada indivíduo deve organizar o seu caos interior, refletindo sobre as suas verdadeiras necessidades [...] o seu caráter forte e autêntico se recuse a sempre repetir, aprender, imitar [...]." (NIETZSCHE, 2015, p. 117). Desse modo, têm-se em Ham on Rye um romance histórico contemporâneo que possui uma conduta revolucionária não visando a coletividade como quer Lukács, mas sim o individual, como implica Nietzsche. Henry Junior, ao recusar a história, negando os valores pregados pela escola, nação e família, há de buscar outra fonte de conhecimento: a literatura, a ser analisado na próxima seção.

\subsection{Há catarse de Henry Junior?}

Neste capítulo, tenho discorrido sobre como a dialética, o materialismo histórico e a busca por autoconhecimento fazem parte do realismo lukácsiano de Ham on Rye e sobre como as representações de Bukowski sobre o conflito sujeito-objeto podem retornar à realidade concreta como forma de questionamento da sociedade e do sistema vigente, tanto por parte da personagem Henry Junior, como do leitor de Ham on Rye. Esse retorno está, de acordo com a teoria de Lukács, no grande romance realista e deve ser almejado na arte. A contemplação passiva, a mera imitação da natureza alija a liberdade do homem. A arte como 
práxis, como pensa Marx, é intervenção (FREDERICO, 2013). A arte, portanto, possui uma função social (FREDERICO, 2013), não sendo mero entretenimento ou objeto de luxo. E esta função está relacionada com a aquisição de autoconhecimento. Ou então como pensa Nietzsche (2015) em relação à história, a arte é uma forma de libertação dos fatos cristalizados, um modo de resgatar o valor positivo da história.

Lukács retoma a contraposição aristotélica entre história e poesia, tratando-as dialeticamente, consequentemente, estabelecendo interações entre elas (BASTOS, 2012) ao dizer que a poesia possui função na história, não está isolada dela. Tal interação, em comum tanto para Lukács e Nietzsche quanto para Eagleton (1983), nos ajuda a estabelecer um liame entre literatura e política em Ham on Rye. O público e privado se separam na vida por causa do conflito de classes e a literatura é o espelhamento da vida. Portanto, ela deve retratar essa cisão. Celso Frederico (2013, p. 133) pode contribuir nesta questão:

A vida cotidiana é o ponto de partida e o ponto de chegada: é dela que provém a necessidade de o homem objetivar-se, ir além de seus limites habituais; e é para a vida cotidiana que retornam os produtos de suas objetivações. Com isso a vida social dos homens é permanentemente enriquecida com as aquisições advindas das conquistas da arte e da ciência.

A vida cotidiana como a temos, em um contexto de conflito de classes, não é suficiente para o homem, pois é desarmonicamente desumana. O conhecimento adquirido por meio da arte permite ao indivíduo se entender como participante do gênero humano. Charles Bukowski faz com que sua personagem conquiste maior percepção a cerca do mundo objetivo através da subjetividade literária. A compensação junguiana ou fuga freudiana por meio da arte ganha aqui a forma de catarse lukácsiana:

Segundo Lukács, o indivíduo supera a sua singularidade e é posto em
contato com o gênero humano. O exemplo mais claro é o fenômeno da
catarse, que permite restabelecer o nexo do indivíduo com o gênero. Esse
nexo fica esmaecido na cotidianidade, na qual os homens encontram-se
fragmentados e entregues à resolução dos problemas pessoais de sua vida
privada. [...] o homem mobilizado pela arte volta a defrontar-se com a
fragmentação do cotidiano [e] enriquecido pela experiência que o colocou
em contato com o gênero passará a ver o mundo com outros olhos.
(FREDERICO, 2013, p. 135)

O prazer estético, de acordo com Lukács, vem da catarse desfetichizante. O homem, estando desfetichizado, passa a se perceber pertencente ao gênero humano (LUKÁCS, 2009). Em vista disso, uma função social da arte é recriar o homem desumanizado, aniquilado e fragmentado pelo Capitalismo. O desafio da verdadeira arte, portanto, segundo Lukács (2009) 
é combater a opressão desumanizadora do sistema capitalista e desmascarar a reificação, isto sendo possível pela busca e possível encontro com a totalidade dentro do mundo.

Henry Junior, que inicialmente percebe o nacionalismo automatizado e acrítico dos estadunidenses, posteriormente entra em contato com a alienação do trabalho capitalista, uma atividade sem sentido que trava potencialidades humanas, e o utilitarismo econômico dos EUA, tendo então a sensibilidade depauperada: "Os bloqueios sociais impõem-se ao homem e atrofiam os seus sentidos" (FREDERICO, 2013, p. 47) e a arte surge como contraponto a essa alienação. Ao pensar nos escritores descobertos na biblioteca, Henry Junior pondera: "Para mim, esses homens que vieram na minha vida do nada eram minha única chance. Eles eram as únicas vozes que falavam comigo." ${ }^{162}$ (BUKOWSKI, 1982, p. 166). As aulas, os discursos de presidentes, a palestra do chefe no primeiro dia de emprego e principalmente as falas do pai na sala de jantar são mais bem compreendidas após o encontro com a voz da arte. Henry Junior consegue por intermédio da literatura um acesso ao entendimento das contradições do mundo capitalista estadunidense no entre guerras, o mesmo entendimento que é escondido pelo Aparato Ideológico do Estado escola e impossível de se alcançar dentro da casa da personagem.

Uma vez que a sociedade capitalista produz uma "divisão do homem entre cidadão e indivíduo privado e isolado" (FREDERICO, 2013, p. 71), esse movimento que produz um possível encontro com a totalidade nunca é de fato terminado. Estabelece-se aqui, um vínculo com Jung: o fato de a maturação da personalidade ser inatingível não deve impedir o indivíduo de buscá-la, e o mesmo vale para a busca da totalidade. Stuart Hall (1999, p.11) pondera que "identidade é formada na interação entre o eu e a sociedade", o que nos leva a uma costura entre o social, o psicológico e o político na constituição do sujeito, em Ham on Rye representado por Henry Junior.

Lukács (2000) afirma que a verdadeira arte não nasce do agradável, ela nasce do caos do mundo e confere sentido à ausência de sentido. Henry Junior, primeiramente ao ler, e posteriormente ao escrever, busca sentido na vida ausente de sentido. O sentido da vida, ou fim para Nietzsche (2015), não existe. Mesmo sem encontrar sentido, Henry Junior não para de tentar obtê-lo. Da mesma forma que a personalidade nunca estará amadurecida por completo, conforme o capítulo anterior, o sentido da vida não pode ser encontrado. Porém, a busca, e não o encontro, é que traz conhecimento para o indivíduo. Em Ham on Rye, esse embate entre vida sem sentido e arte mais uma vez ganha relação metonímica por meio do

\footnotetext{
162 "To me, these men who had come into my life from nowhere were my only chance. They were the only voices that spoke to me."
} 
conflito de Henry Junior e seu pai. Ao saber que o filho está tendo acesso à literatura no quarto, ele o obriga a apagar as luzes à noite para que possa dormir cedo e trabalhar renovado no dia seguinte. Henry Junior começa então a ler escondido:

Quando a verdade de alguém é a mesma verdade que a sua, e ele parece estar dizendo só para você, é ótimo. Eu lia meus livros à noite, desse jeito, debaixo do edredom com a luz de leitura superaquecida. Ler todas aquelas boas linhas enquanto sufocava. Era mágico. E meu pai havia encontrado um emprego, e aquilo era mágico para ele... ${ }^{163}$ (BUKOWSKI, 1982, p. 166)

Essa imagem é mais uma costura por entre os capítulos desta dissertação, agora com o uso de metáforas. O pai, simbolizando o patriarca repressor, dita as ordens, por mais que sem sentido que elas sejam. O filho reprimido socialmente, e agora fisicamente por um edredom, presencia um encontro de arquétipos, da luz dentro da escuridão da sua coberta sufocante, não só a luz empírica do abajur, mas a luz do autoconhecimento promovido pela arte. O edredom é o mundo que o sufoca, é a escuridão do Capitalismo e seu propagador representado pelo pai, que reprime o sujeito interessado em conhecimento por meio da arte. A arte é a luz e o autoconhecimento. A arte é a magia para o indivíduo de posse de autoconhecimento, já para o indivíduo reificado, a magia é possuir um emprego qualquer.

Utilizando outras nomenclaturas cunhadas por Lukács, o pai de Henry Junior é o 'homem inteiro' enquanto que o protagonista é o 'homem inteiramente': “Lukács designa o homem imerso na cotidianidade de 'o homem inteiro' para contrapô-lo ao 'homem inteiramente', aquele concentrado na arte [...].” (FREDERICO, 2013, p. 135). O pai de Henry Junior, símbolo do indivíduo sujeitado ao Capitalismo, é hostil à arte, é um homem que não enxerga, ou se nega a enxergar, as contradições do sistema capitalista. Já Henry Junior, é um indivíduo que através da arte consegue vislumbrar uma possível e diferente saída. Aqui há o que Lukács (FREDERICO, 2013) chama de tensão entre 'querer' e 'ser capaz'. O pai de Henry Junior é a personificação da reificação e do efeito dela: ele apenas quer o que a sociedade o ensinou a querer e não possui conhecimento necessário para perceber isso. Já Henry Junior é a contraposição dialética do pai: mesmo que sejam parecidos, Henry Junior não quer ser como pai e sente-se capaz de não querer. $\mathrm{O}$ efeito estético da arte, ou catártico, que para Lukács também é ético (BASTOS, 2012) devido ao seu caráter político, retorna à realidade de Henry Junior, fazendo-o enxergar os limites impostos pela imediatez da sociedade capitalista e a questionar novas possibilidades em sua vida cotidiana. $\mathrm{O}$ ser capaz

\footnotetext{
163 "When someone else's truth is the same as your truth, and he seems to be saying it just for you, that's great. I read my books at night, like that, under the quilt with the overheated reading lamp. Reading all those good lines while suffocating. It was magic. And my father had found a job, and that was magic for him ..."
} 
de não querer adquire dimensões éticas em Henry Junior uma vez que ele percebe que a ação ou movimento dos homens reificados são fonte de seu displaçamento.

Conforme Lukács (2000, p. 87 e 91), o romance não é uma realidade, é uma exigência da realidade: "O romance é a forma da aventura do valor próprio da interioridade; seu conteúdo é a história da alma que sai a campo para conhecer a si mesma [...]." Parte disso é encontrado em Ham on Rye. De acordo com o que foi analisado no capítulo anterior desta dissertação, Henry Junior busca se esconder como forma não consciente de desenvolver a sua própria personalidade. No mesmo capítulo da narrativa em que pensa em se isolar, Henry Junior discute com Becker, o único amigo, que também quer ser escritor e quem incentiva Henry Junior a viajar e fazer coisas para o protagonista obter material para escrever:

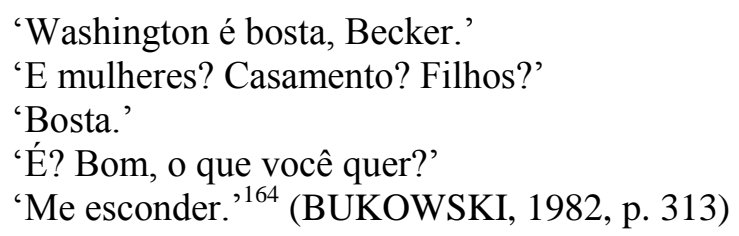

Eles já haviam discutido três capítulos antes sobre o ofício de escritor:

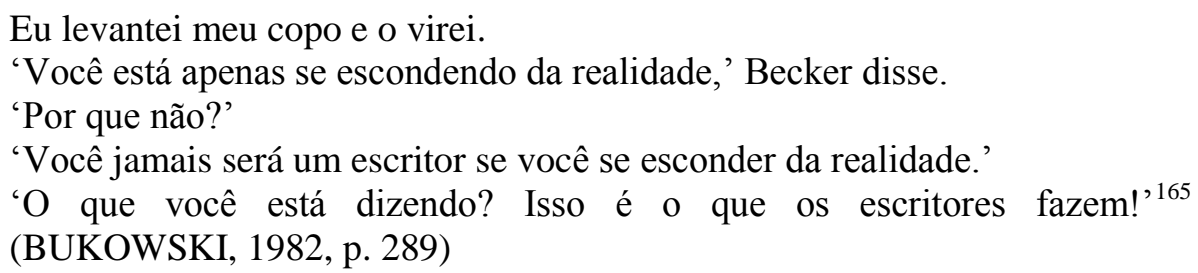

Por meio de Henry Junior, Charles Bukowski problematiza a função da literatura e do escritor na sociedade. A dimensão político-ética que a literatura ganha em Ham on Rye perpassa pelo pensamento nômade de Cresswell (2006), mencionado no primeiro capítulo da dissertação e pelo desenvolvimento da personalidade do segundo. Becker representa o escritor conformista do entre guerras do século passado. Ele vai à guerra e quer o que a sociedade o oferece. Enquanto Henry Junior, que também quer ser escritor, já de posse de autoconhecimento, decide transgredir o que o amigo prega, percorrendo o caminho contrário. A fixidez perante o movimento dos EUA em direção à guerra, transgredindo o que é proposto pela nação, faz com que Henry Junior se isole ou busque se esconder como forma de desenvolver a sua personalidade e tentar construir a sua própria história, tanto como indivíduo quanto escritor.

\footnotetext{
164 “'Washington's crap, Becker.' 'And women? Marriage? Children?' 'Crap.' 'Yeah? Well, what do you want?' 'To hide."”

165 'I raised my glass and drained it. 'You're just hiding from reality,' Becker said. 'Why not?' 'You'll never be a writer if you hide from reality.' 'What are you talking about? That's what writers do!'
} 
No entanto, a catarse de Henry Junior não escapa à dialética. Independentemente de Henry Junior contrariar o sonho americano ao negar a busca de sucesso financeiro, fama, estabilidade ou quaisquer bens materiais, fruto de sua desobediência e negação dos valores estadunidenses, isso o faz ainda mais parecido com o pai. O desejo de Henry Junior em ser a antítese do pai não se realiza, pois a dialética não permite. Apesar de buscar e se preocupar com o livre-arbítrio, Henry Junior na verdade é tão vítima da reificação quanto o pai, por mais doloroso que seja aceitar isso. Ao tentar ser diferente dos que o marginalizam, Henry Junior se transforma em algo parecido com eles. Assim como o pai, que projeta suas deficiências para o externo, levando-o a atitudes hipócritas, Henry Junior por muitas vezes acaba fazendo o mesmo.

Conforme analisado acima, Henry Junior tem vergonha de possuir uma bicicleta na presença dos alunos que têm automóveis, e acaba por escondê-la. Quer ser durão, mas foge de algumas brigas. Ao longo de toda a narrativa, critica a brutalidade covarde do pai, porém, ele mesmo se transforma em um bully com os mais fracos, sejam eles colegas de escola ou meros desconhecidos. Henry Junior, ao demonstrar possuir características similares as que ele sempre critica e despreza em outras pessoas, evidencia o caráter cíclico da história em um indivíduo. No desfecho de Ham on Rye, logo após o amigo Becker se apresentar para lutar na II Guerra, Henry Junior entra em um fliperama e começa a jogar contra uma criança e pensa consigo: "Eu senti que eu tinha que vencer. Parecia muito importante. Eu não sabia por que era importante e pensava, por que eu acho isso tão importante? $\mathrm{E}$ outra parte de mim respondeu, apenas porque é."166 (BUKOWSKI, 1983, p. 318). Para Nietzsche (2015), o homem de ação determina as suas próprias limitações, contudo, dialeticamente, em Ham on $R y e$, isso é um processo contínuo que não se encerra ao fim da narrativa.

De acordo com Nietzsche (2015), a história é uma sucessão de acasos, e devemos trazê-los à luz para pararmos de nos entregar a eles. Assim como na coletividade, a ciclicidade ocorre em dimensões individuais. Henry Junior quer inicialmente participar de grupos, para depois os recusar. Ainda assim, mesmo recusando o que a sociedade prega, ele igualmente é uma vítima e de certa forma perpetuador do que ela dissemina. Isto posto, a catarse como preconiza Lukács é questionada por meio de Henry Junior em Ham on Rye. A arte possui sim função social na vida do protagonista e há de ter a mesma função na vida concreta dos leitores de romances realistas. Porém, deve-se sempre atentar para o processo ininterrupto e dialético de busca de conhecimento, pois a história oficial e a ideologia dominante estão emaranhadas

\footnotetext{
166 "I felt I had to win. It seemed very important. I didn't know why it was important and I kept thinking, why do I think this is so important? And another part of me answered, just because it is."
} 
na cultura de um povo e hão de afetar constantemente o indivíduo, mesmo que esteja num processo de desfetichização.

Cabe concluir que a maturidade ou o amadurecimento da personalidade é fruto da catarse de Henry Junior frente à coletividade que consente com a parcialidade da história. Henry Junior é um indivíduo que não se conforma com leis postas e esse inconformismo é em parte promovido e desvendado pela arte, que para a personagem não é uma salvação, mas uma forma dela confrontar a história a fim de escrever a sua própria. A arte para Nietzsche (2015, p. 180) é uma força supra-histórica, um remédio contra a mumificação, contra a mutilação limitante da história, é a "manifestação visível das esperanças e dos desejos mais íntimos" e deve ir para frente, ao contrário do sentido histórico, que o filósofo alemão tanto critica. $\mathrm{O}$ valor positivo da história retorna a Henry Junior por meio da arte. Ao perceber a ciclicidade tendenciosa da história humana, há de se conseguir uma mudança com tal percepção. É nesse sentido nietzschiano que a arte funciona como catarse para Henry Junior, como uma transfiguração da história oficial a fim de ajudar na maturação da personalidade. 


\section{CONSIDERAÇÕES FINAIS}

Nesta dissertação, a obra Ham on Rye foi investigada seguindo três principais núcleos: sociológico, psicanalítico e histórico-dialético. No primeiro capítulo, examinei como a coletividade humana se articula de maneira a se constituir como algo naturalmente imperante sob os olhos dos indivíduos que a compõe. Já no segundo capítulo, meu interesse foi apurar os efeitos dessa articulação no indivíduo, especialmente se este não está de acordo com as determinações postas por aquele, como é o caso da personagem Henry Junior na narrativa. Finalmente, no terceiro e último capítulo, meu objetivo foi entender como se dá o diálogo entre a coletividade e o individual, e entre a obra e a realidade objetiva por meio da dialética materialista em suas variadas mediações.

Em uma análise superficial do comportamento da personagem Henry Junior, pode-se concluir que ele representa um sujeito niilista, egoísta e individualista, como alguns críticos literários já o fizeram. Contudo, mesmo que a personagem realmente possua as características acima, levando-se em conta a minha análise, Charles Bukowski apresenta em Ham on Rye o que Lukács designaria como arte sendo a memória da humanidade (FREDERICO, 2013), ou, conforme o último capítulo desta dissertação, a arte como contestação da história oficial (NIETZSCHE, 2015; RUSHDIE, 1991). Portanto, Bukowski não simplesmente retrata a época de infância de seu protagonista niilista, mas problematiza a articulação da hegemonia estadunidense por meio dessa personagem mediana. Lukács (2000, p. 35) afirma: “[A] arte [...] tem como pressupostos de sua existência e conscientização, o esfacelamento e a insuficiência do mundo." Essa insuficiência do mundo percebida por Henry Junior na coletividade da qual faz parte é tanto um reflexo das contradições da sociedade estadunidense quanto ingrediente primordial do displaçamento da personagem, mas que ao mesmo tempo, a faz perceber a existência da arte, uma objetivação humanizadora que a educa e a permite entender melhor as causas dessa mesma insuficiência, promovendo assim novas possibilidades para além do que é proposto ou imposto pela coletividade.

A despeito de Henry Junior aparentemente se humanizar ao fim de Ham on Rye, a emancipação política idealista pretendida por Lukács não acontece por completo na narrativa. A ampliação do senso crítico e o amadurecimento da personalidade são as conquistas de Henry Junior, que de forma alguma devem ser desprezadas, mas que são insuficientes como meios de confrontar a ideologia dominante. Com o conhecimento adquirido por meio da literatura, Henry Junior se vê pertencente ao gênero humano, como prega Lukács. No entanto, 
a personagem se vê pertencente a um gênero totalmente reificado, sendo que ele mesmo está reificado. Portanto, o valor em se entender como participante do gênero é questionado por Charles Bukowski: se o sujeito está reificado e faz parte de um gênero reificado, qual a possível vantagem em se enxergar pertencente ao mesmo? Cabe-nos voltar à história.

O conceito pós-Revolução Francesa de indivíduo participante na história permeia a construção da personagem de Ham on Rye. Henry Junior é um sujeito ativo que tem os instintos despertados (NIETZSCHE, 2015) por meio da arte. De posse desses instintos, a personagem consegue enxergar as conexões da história e das relações entre os homens e a sociedade, como o 'sonho americano' inatingível para os pobres ou o falso patriotismo, conquistando então uma prática social mais consciente, e, portanto, menos alienada. O prazer catártico aristotélico da arte é transmutado em uma forma de ajudar Henry Junior a amadurecer e a atingir autoconhecimento, e, consequentemente, certa emancipação política. Como a personagem mesma diz, ela não está interessada na história, ou seja, nos fatos. Desconfiado, o protagonista renega os livros da escola, local de reprodução da doutrina capitalista e do status quo. De fato, ele se interessa pelos romances que encontra na biblioteca, nos quais pode realmente encontrar conhecimento, corroborando Nietzsche (2015) e Eagleton ([1983] 1996): ao consumir arte, Henry Junior se encontra com o possível, afastando-se de uma vida mecânica.

Ainda que a personagem se encontre parcialmente humanizada pelo contato com a literatura, esse 'possível' não proporciona um 'final feliz' à narrativa, uma vez que o protagonista não consegue, por fim, se ver totalmente livre dos limites da hegemonia: ao buscar a vitória sem saber por que ela é importante, Henry Junior termina a narrativa se contradizendo performaticamente do mesmo modo que seu pai. Conforme visto na seção sobre ideologia, hegemonia é a ideologia posta em prática. Ela está sempre sofrendo pressão de hegemonias alternativas, fazendo-a se modificar para perdurar (WILLIAMS, 1977). Ao questionar as forças dominantes, Henry Junior é uma representação de uma força contrahegemônica. Se conforme visto em toda a dissertação, a personagem, por inúmeras vezes, age da mesma forma e quer as mesmas coisas que os típicos indivíduos subordinados à hegemonia, parece-me discutível que ele obteve sucesso nesse confronto. Entendo, portanto, que há uma indicação de que o processo contra-hegemônico nunca deve ser considerado terminado. O pseudo final infeliz remete a um trabalho árduo de busca de autoconhecimento que não cessa, pois as forças hegemônicas, que no caso da narrativa são o Capitalismo, a cultura estadunidense e a história a serviço delas, são por demais fortes e devem ser 
combatidas e desmascaradas sempre em um processo contínuo. $\mathrm{O}$ encerramento da narrativa não é o fim da busca por entendimento sobre a fragmentação das relações sociais.

A despeito da sociedade capitalista estadunidense esfacelar as relações sociais entre os indivíduos, quando há uma iminente guerra, os EUA disseminam uma falsa identidade coletiva a fim de unificar o país. Ora, se Henry Junior quando buscou pertencer à coletividade foi sumariamente excluído, por que agora, em um evento que pode tirar a sua vida como a guerra, ele iria finalmente se unir a nação que sempre o rechaçou? A fixidez de resistência niilista de Henry Junior o remete à desobediência civil de Henry David Thoreau (1849). Assim como este, a personagem de Ham on Rye vê os homens servindo o Estado como máquinas sem questioná-lo:

Casar, ter filhos, cair na armadilha da estrutura familiar. Ir para um lugar trabalhar todo dia e voltar. Era impossível. Fazer coisas, coisas simples, fazer parte de piquenique de família, natal, 4 de julho, dia do trabalho, dia das mães... um homem nasce somente para aguentar essas coisas e então morrer? Eu preferia ser um lavador de pratos, voltar sozinho para um quarto pequeno e beber até dormir. ${ }^{167}$ (BUKOWSKI, 1983, p. 213)

A personagem busca sua independência ao decidir não querer nada do que o pai, governo dos EUA e seus Aparelhos Ideológicos do Estado pregam, sugerem ou ordenam. Corroborando o que Jung ([1954] 1988) diz sobre o desenvolvimento da personalidade no capítulo 3 deste estudo, Henry Junior foge das convenções coletivas para viver sob as próprias leis. Essa é a verdadeira revolução para Thoreau (1849): "Você deve viver de acordo com você mesmo e depender de si mesmo, sempre com mangas arregaçadas e pronto para um começo"168 e Henry Junior é um representante contemporâneo desta 'revolução' contrahegemônica. Assim sendo, se o Capitalismo e suas expressões ideológicas são cíclicos, o combate deve ser igualmente cíclico. Se a hegemonia 'dialoga' com as forças contrárias estabelecendo limites a esta a fim de se manter hegemônica, as forças contra-hegemônicas devem da mesma forma estabelecer limites contra a atuação da ideologia dominante. Mesmo que, por vezes, Henry Junior se encontre influenciado pela hegemonia, ele estabelece limites contra os princípios postos pela comunidade imaginada, desobedecendo-a e ignorando-a.

No tocante a sofrer com os limites hegemônicos, quando criança, Henry Junior tenta inicialmente se inserir no grupo dos colegas de escola e da rua. O pertencimento à

\footnotetext{
167 "To get married, to have children, to get trapped in the family structure. To go someplace to work every day and to return. It was impossible. To do things, simple things, to be part of family picnics, Christmas, the 4th of July, Labor Day, Mother's Day . . . was a man born just to endure those things and then die? I would rather be a dishwasher, return alone to a tiny room and drink myself to sleep."

168 "You must live within yourself, and depend upon yourself, always tucked up and ready for a start."
} 
coletividade é tido como humanizador frente ao isolamento familiar sofrido pela personagem, pois o grupo representa proteção e segurança não encontrados no lar. Contudo, conforme percebido pela personagem e analisado aqui, a formação de grupos na sociedade estadunidense estabelece como um dos seus parâmetros a existência do 'outro'. Ou seja, para que haja um grupo, há de existir indivíduos que não possam fazer parte dele, que por muitas vezes podem ser não somente excluídos, mas também combatidos. O misfit, o desajustado ou o diferente excluído na escola pode um dia se transformar em um inimigo da comunidade. A sociedade que outrora rejeitou os negros como cidadãos estadunidenses, inclusive no pósGuerra de Secessão (1861-1865), tanto empiricamente quanto por meio de teorias eugenistas, é a mesma que estabelece que a língua alemã não deve ser mais ensinada ou sequer usada nos EUA no período entre guerras no século passado; a sociedade que questiona a presença latina nos EUA, principalmente no pós-II guerra, é a mesma que agora discrimina as comunidades árabes presentes no país. Portanto, a construção e manutenção da comunidade imaginada dos EUA tem como base ideológica a criação de um inimigo comum como forma de unir os indivíduos da nação. Henry Junior percebe isso não somente em termos étnicos, mas também pelo conflito de classes e por meio da escrita da história que é contada pela classe dominante. Ora o protagonista é excluído por causa de sua origem alemã, ora por causa de sua classe. Logo, Henry Junior consegue constatar que a comunidade imaginada não é articulada por meio da comunhão, mas por meio da exclusão. E excluir faz parte de diferentes esferas da sociedade, lembrando que, segundo Brah (1996), as minorias também marginalizam outras minorias, sendo esta uma atitude que corrobora a hegemonia, favorecendo quase que exclusivamente os dominantes.

Daí mais uma vez a união entre arte e política exposta em Ham on Rye. O passado como pré-história do presente está na realidade e é representado na narrativa de Bukowksi. O autor, conforme analisado acima, não propõe por meio de sua personagem uma solução para a sociedade Capitalista. Inclusive, talvez não haja solução, pois a reificação provocada pela hegemonia limita as ações e pensamentos de Henry Junior, mesmo este de posse de uma personalidade mais madura. Não há solução na narrativa, pois metonimicamente talvez não haja solução na vida concreta, porém há resolução. A desobediência e fixidez de resistência de Henry Junior demonstram ser o 'gol de honra' da personagem contra a hegemonia. Sem solução, o final de Ham on Rye parece delegar ao leitor a responsabilidade de refletir sobre a escrita da história, questionar a construção de comunidades imaginadas e convidá-lo a interrogar a ideologia dominante. Desse modo, Henry Junior é, sim, uma personagem niilista, 
mas a representação da negação do mundo em Ham on Rye pode ser um vislumbre de uma saída para a vida. 


\section{REFERÊNCIAS BIBLIOGRÁFICAS}

ABBAGNANO, Nicola. Dicionário de filosofia. São Paulo: Martins Fontes, 2007. 1014 p.

AHMED, Sara. Home and Away: Narratives of Migration and Estrangement. In: Strange Encounters: Embodied Others in Post-Coloniality. London; New York: Routledge, 2000. p. 77-94.

ALTHUSSER, Louis. Ideologia e aparelhos ideológicos do estado. Traduzido por Joaquim José de Moura Ramos. Lisboa: Editora Presença, 1970. 121 p.

ANDERSON, Benedict. Imagined Communities. London: Verso, 1991. 224 p.

ARENDT, Hannah. A Nação. In: Compreender: formação, exílio e totalitarismo. São Paulo: Cia. das Letras; Belo Horizonte: Ed. UFMG, 1994, p. 234-239.

ARISTÓTELES. Arte poética. Disponível em: 〈www.psb40.org.br/bib/b2.pdf>. Acesso em 10 de agosto de 2016.

BACHELARD, Gaston. A Poética do Espaço in: A filosofia do não ; O novo espírito científico; A poética do espaço; seleção de textos de José Américo Motta Pessanha. Traduzido por Joaquim José Moura Ramos et al. São Paulo: Abril Cultural, 1978. p. 182-354.

BASTOS, Hermenegildo. Arte e vida cotidiana: a catarse como caminho para a desfetichização. 2012. Disponível em: <http://www.herramienta.com.br >. Acesso em 17 de julho de 2015.

BASTOS, H.; ARAÚJO, A. (Orgs.). Teoria e prática da crítica literária dialética. Brasília: Editora Universidade de Brasília, 2011. 182 p.

BAUGHMAN, Judith S. American Decades 1920 - 1929. Detroit: Gale Research Inc., 1996. $554 \mathrm{p}$.

BONDI, Victor. American Decades 1930 - 1939. Detroit: Gale Research Inc., 1996. 612 p.

BOURDIEU, Pierre. A Distinção. Traduzido por Daniela Kern e Guilherme. F. Teixeira. São Paulo: EDUSP, 2006. 556 p.

BRAGA, Cláudio Roberto Vieira; GONÇALVES, Gláucia Renate. A diáspora na obra de Karen Tei Yamashita : Estado-nação, sujeito e espaços literários diaspóricos. 2010. 208 f., enc. : Tese (doutorado) - Universidade Federal de Minas Gerais, Faculdade de Letras.

BRAH, Avtar. Diaspora, Border and Transnational Identities. In: Cartographies of Diaspora: Contesting Identities. London; New York: Routledge, 1996. p. 178-248.

BUKOWSKI, Charles. Ham on Rye. UK: Canongate, 1982. 318 p. 
Sunlight Here I Am: Interviews \& Encounters 1963 - 1993. Edited by David Stephen Calonne. Northville: Sun Dog Press, 2003. 288 p.

CHAMBERS, Iain. Migrancy, Culture, Identity. London: Routledge, 1994. 154 p.

CHERKOVSKI, Neeli. Bukowski: A Life. New York: Random House, 1991. 352 p.

CLIFFORD, James. Diasporas. In: Routes: Travel and Translation in the Late Twentieth Century. Cambridge e London: Harvard University Press, 1997. p. 244-277.

CRESSWELL, Tim. On the Move. New York: Routledge, 2006. 327p.

DIAMOND, Jared. Guns, Germs and Steel. New York: Norton, 1997. 494 p.

DOBIE, Ann B. Theory Into Practice: An Introduction to Literary Criticism. Boston: Wadsworth, 2002. 376 p.

EAGLETON, Terry. Ideology: An Introduction. London: Verso, 1991. 242 p.

Literary Theory: An Introduction. Minneapolis: The University of Minnesota Press, [1983] 1996. 234 p.

ENGELS, Frederick. Socialism: Utopian and Scientific. 1880. Disponível em <https://www.marxists.org/archive/marx/works/1880/soc-utop/ch03.htm>. Acesso em $10 \mathrm{de}$ julho de 2016.

ERENBERG, Lewis A. The Greatest Fight of Our Generation: Louis vs. Schmeling. New York: Oxford, 2006. 273 p.

FACINA, Adriana. Literatura e sociedade. Rio de Janeiro: Jorge Zahar Editor LTDA, 2004. $55 \mathrm{p}$.

FRANÇA, Júnia Lessa. Manual para normalização de publicações técnico-científicas. 8 . ed. Belo Horizonte: Ed. UFMG, 2006. 256 p.

FREUD, Sigmund. Creative Writers and Day-dreaming. (discurso) 1908. Disponível em: $<$ http://www.kleal.com/AP12\%20member\%20area\%20pd2\%202013/Freud\%20and\%20Frye. pdf $>$. Acesso em 02 de março de 2016.

Interpretação dos sonhos. Rio de Janeiro: Imago, [1899] 1987. 362 p.

O mal-estar na civilização. Rio de Janeiro: Imago, [1930] 1997. 112 p.

Totem e tabu. Tradução de Paulo César de Souza. São Paulo: Penguin \& Companhia das Letras, [1913] 2013. 169 p.

GEORGE, Rosemary Marangoly. The Politics of Home. Berkeley: California University, 1999. $265 \mathrm{p}$. 
HALL, Stuart. A identidade cultural na pós-modernidade. Rio de Janeiro: DP\&A, 1999. 102 p.

. Cultural Identity and Diaspora. In: RUTHERFORD, J (Ed.). Identity: Community, Culture, Difference. London: Lawrence \& Wishart, 1990. p. 222-237.

HARRISON, Russel. Against the American Dream: Essays on Charles Bukowski. Santa Rosa: Black Sparrow, 1994. 331 p.

HELLER, Agnes. History and the Historical Novel in Lukács. In: THOMSON, Philip e ROBERTS, David. The Modern German Historical Novel. New York/Oxford: Berg, 1991. p. 19-33.

HOBSBAWN, Eric. Era dos extremos: O breve século XX. Tradução de Marcos Santarrita. São Paulo: Companhia das Letras, 1995. 598 p.

JUNG, C.G. O desenvolvimento da personalidade. Tradução de Valdemar do Amaral. Petrópolis: Vozes, [1954] 1988. 223 p.

Os arquétipos e o inconsciente coletivo. Tradução de Maria Luíza Appy e Dora Mariana R. Ferreira da Silva. Petrópolis: Vozes, [1976] 2002. 408 p.

KIRSCH, A. Smashed - The Pulp Poetry of Charles Bukowski. 2014. Disponível em <http://www.newyorker.com/magazine/2005/03/14/smashed>. Acesso em 27 de abril de 2016.

LACAN, Jacques. Escritos. Rio de Janeiro: Zahar, 1998. 937 p.

Nomes-do-pai. Tradução de André Telles. Rio de Janeiro: Zahar, 2005. 93 p.

LUKÁCS, György. A teoria do romance: um ensaio histórico filosófico. Tradução de José Marcos Mariani de Macedo. São Paulo: Editora 34º; Duas Cidades. 2000. 236 p.

Arte e sociedade. Escritos estéticos 1932-1967. Tradução de Carlos Nelson Coutinho e José Paulo Netto. Rio de Janeiro: Editora UFRJ, 2009. 275 p.

As bases ontológicas do pensamento e da atividade do homem In: Temas de ciências humanas. São Paulo: Livraria Editora Ciências Humanas, 1978. p. 1-18

História e consciência de classe. Tradução de Rodnei Nascimento. São Paulo: Martins Fontes, 2003. 598 p.

O romance histórico. Tradução de Rubens Enderle. Rio de Janeiro: Boitempo Editorial, [1955] 2011. 438 p.

Pensamento vivido: autobiografia em diálogo. Tradução de Cristina Alberta Franco. Viçosa: Editora UFV, 1999. 187 p. 
LYE, John. Psychoanalysis and Literature, 1996. Disponível em: <http://www.jeeves.brocku.ca/english/courses/4F70/psychlit.php>. Acesso em 10 de julho de 2015

MANN, Arthur. From Immigration to Acculturation. In: Making America. Washington, D.C.: United States Information Agency, 1987. p. 68-80.

MARX, Karl. Estranged Labour, 1844. Disponível em: <www.marxists.org/archive/marx/works/1844/manuscripts/labour.htm>. Acesso em 10 de novembro de 2015.

NIETZSCHE, Friedrich. Escritos sobre história. Tradução de Noéli Correia de Melo. São Paulo: Folha de São Paulo, 2015. 238 p.

PESSEN, Edward. Status and Social Class in America. In: Making America. Washington, D.C.: United States Information Agency, 1987. p. 270-281.

PHILLIPS, Caryl. A New World Order: Selected Essays. London: Vintage, 2002. 320 p.

POWERS, Richard G. Sports and American Culture. In: Making America. Washington, D.C.: United States Information Agency, 1987. p. 207-220.

PRICE, R. G. Division of Labor, Assembly Line Thought - The Paradox of Democratic Capitalism. 2004, Disponível em:

<http://www.rationalrevolution.net/articles/division_of_labor.htm>. Acesso em 18 de fevereiro de 2016.

RUSHIDIE, Salman. Imaginary Homelands. In: Imaginary Homelands: Essays and Criticism. New York: Penguin, 1991. p. 9-21

SAID, Edward. Reflexões sobre o exílio e outros ensaios. Tradução de Pedro Maia Soares. São Paulo: Companhia das Letras, 2003. 352 p.

Introdução. In: Representações do intelectual: as conferências de Reith de 1993. Tradução de Milton Hatoum Maia Soares. São Paulo: Companhia das Letras, 205. p. 9-18.

SAMUEL, Lawrence R. The American Dream: a Cultural History. New York: Syracuse University Press, 2012. 241 p.

SHARP, Daryl. Jung Lexicon. 1991. Disponível em: <http://www.innercitybooks.net/pdf/books/junglexicon.pdf>. Acesso em 23 de julho de 2016.

SHOLEVAR, G. P.; BENSON, R. M.; BLINDER, B. J. Emotional Disorders in Children and Adolescents: Medical and Psychological Approaches to Treatment. New York: Pergamon Press, 1980. 710 p.

TERTULIAN, Nicolas. O romance histórico. In: Georg Lukács: etapas de seu pensamento crítico. Tradução de Renira Lisboa de Moura Lima. São Paulo: UNESP, 2008. p. 167-187. 
THOREAU, Henry David. Civil Disobedience. 1849. Disponível em: $<$ http://xroads.virginia.edu/ hyper2/thoreau/civil.html>. Acesso em 16 de agosto de 2016.

TINDALL, George Brown. America: a Narrative History. NY: Norton \& Company, 1984 $1343 \mathrm{p}$.

The Ordinary Madness of Charles Bukowski - Documentary. BBC, 1995. Disponível em: <http://www.youtube.com/watch?v=4fxJCb8WZ7Q>. Acesso em 9 de março de 2015

TODOROV, Tzvetan. A literatura em perigo. Rio de Janeiro: DIFEL, 2009. 96 p.

WALZER, Michael. On the Role of Symbolism in Political Thought, 1967 In: ZELINSKY, Wilbur Nation into State: the shifting symbolic foundations of American nationalism. Chapel Hill and London: The University of North Carolina Press, 1988. 350 p.

WILLIAMS, Raymond. Culture and Society 1780-1950. New York: Anchor Books, 1958. $382 \mathrm{p}$.

Marxism and Literature. New York: Oxford University Press, 1977. 217 p.

WOOD, Gordon S. The American Revolution. New York: Modern Library Chronicles, 2002. $190 \mathrm{p}$.

ZELINSKY, Wilbur. Nation into State: the Shifting Symbolic Foundations of American Nationalism. Chapel Hill and London: The University of North Carolina Press, 1988. 350 p.

ZILBERMAN, Regina. O romance histórico - Teoria \& Prática. In: BORDINI, Maria da Glória (org.). Lukács e a literatura. Porto Alegre: PUC/RS, 2003. p. 109-139. 